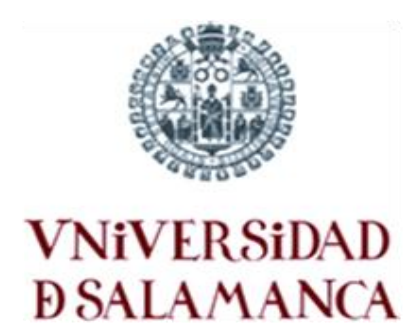

Dpto. de Anatomía e Histología Humanas

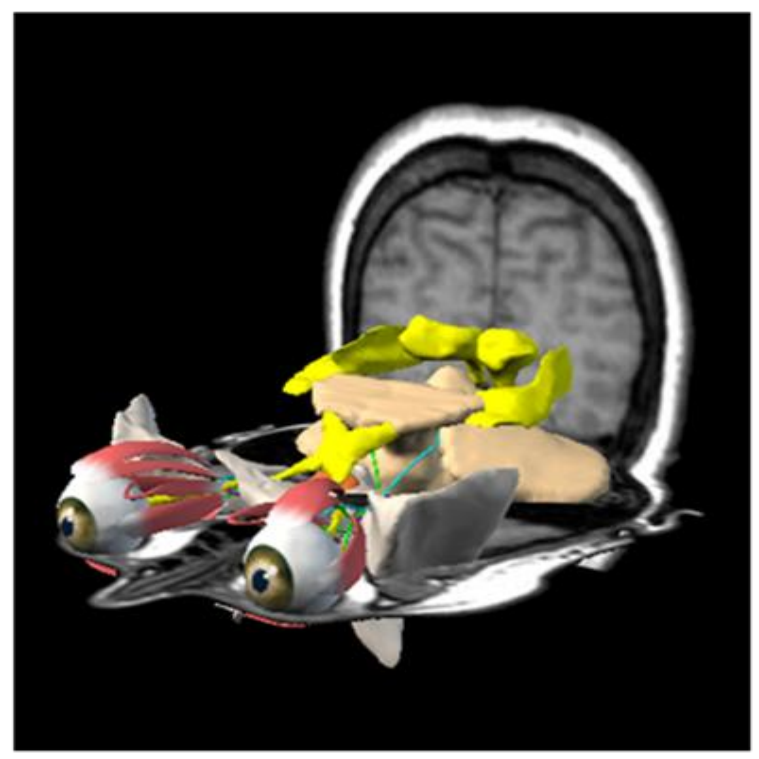

Tesis Doctoral

\title{
ENTORNO VIRTUAL DE VISUALIZACIÓN 3D DE LA VIA ÓPTICA Y SISTEMA OCULOMOTOR, A PARTIR DE SECCIONES SERIADAS DE RESONANCIAMAGNÉTICA
}

Doctorando:

Dña. Ana Ma Riesco del Pino

Directores:

Prof. Dr. Juan Antonio Juanes Méndez

Prof. Dr. José M. Riesco Santos

Prof. Dr. Alberto Prats Galino

\section{Salamanca 2009}


D. Juan Antonio Juanes Méndez, D. Jose Manuel Riesco Santos, Doctores en Medicina y Cirugia, Profesores del Departamento de Anatomía e Histología Humanas de la Universidad de Salamancen y D. Alberto Prats Galino, Doctor en Medicina y Cirugia, Profesor del Departamento de Anatomia IIumana de la Unirersidad de Barcelona

\section{CERTIFICAMOS :}

Que el trabajo titulado "ENTORNO VIKTUAL DE VISUALIZACIÓN 3D DE LA VIA ÓPTICA Y SISTEMA OCULOMOTOR, A PARTIR DE SECCIONES SERIADAS DE RESONANCIA MAGNkTICA", ha sido renlizide por Doin. Ana $M^{*}$ Riesco del Pino, bajo mestra dirucción; reuniendo, a nuestro juicio, los requisitos y méritos suficientes para que la autora del mismo, pueda optar al Grado de Doctor por la Universidad de Salanaancit.

Y para que as/ conste, firmamos la presente certiffcación en Salamanca a veintiocho de ahril de dos mil nueve.
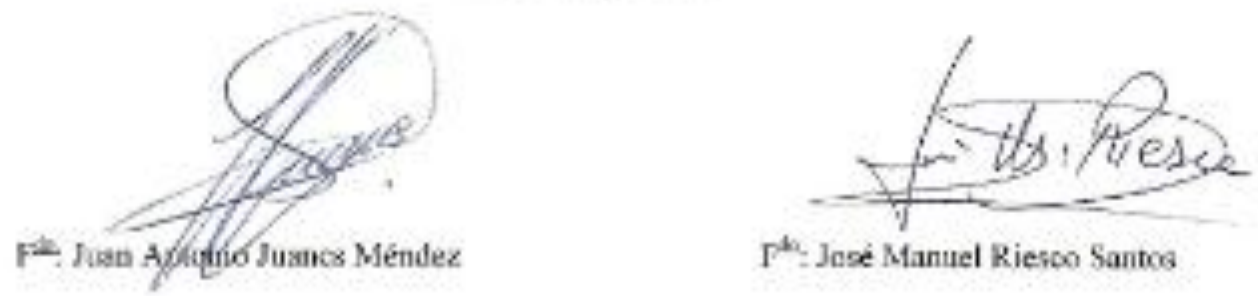

$\Gamma^{\text {be }}$ Jose Manuel Riesco Santco

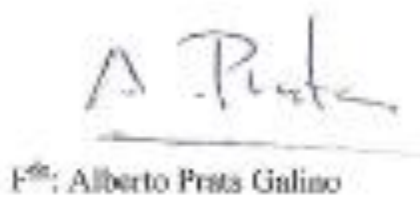




\section{ÍNDICE}

Agradecimientos....................................................... $\quad 7$

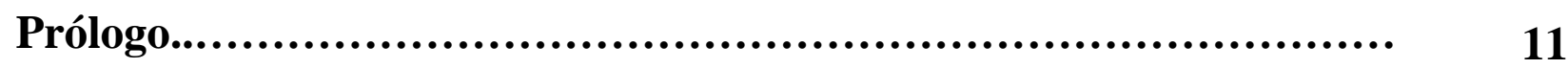

Introducción................................................................ 14

- Recuerdo Histórico................................................................. 16

- Sinopsis anatómica de la vía óptica y del sistema oculomotor anejo............ 19

- Ontogenia de la vía óptica........................................... 25

- Técnicas de diagnóstico por imagen para el estudio de la vía óptica........... 32

Tomografía Computarizada ...................................... 33

Resonancia Magnética .................................................

- Importancia de la imagen 3D para el diagnostico clínico y el 42

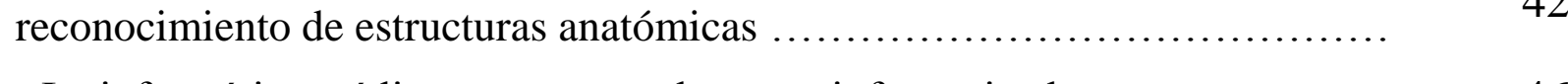

- La informática médica: programas docentes informatizados ................. 46

Planteamiento del Trabajo................................................. 51

Material y Métodos...................................................... 61

- Adquisición y procesamiento de imágenes ............................... 62

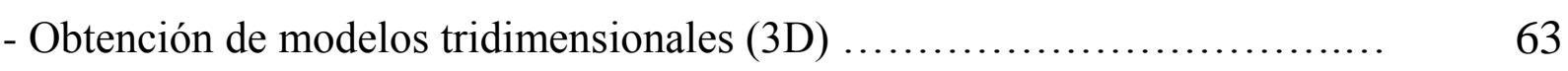

- Visualización y renderización......................................... 65

- Material documental iconográfico........................................ 65 
- Vía óptica........................................................... 70

- Sistema oculomotor...................................................... 76

- Interface gráfico de usuario.......................................... 82

- Valoración del modelo informático.......................................... 88

- Iconografía de Resultados............................................ $\quad 89$

Discusión............................................................... 130

- Consideraciones sobre los desarrollos informáticos como recursos docentes. 134

-Consideraciones sobre el interface de usuario empleado..................... 146

-Consideraciones sobre la aportación de la RM y la imagen 3D en la práctica

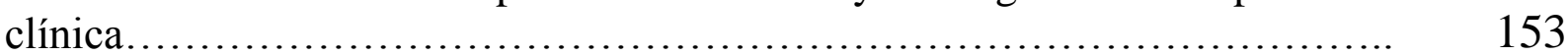

Conclusiones.......................................................... 161

Referencias Bibliográficas............................................. 164 
Con especial cariño para mi abuelo Rufino que siempre me acompaña y para sus hijos: mi padre y mi tio, por su perseverancia. 
"Quien, en su ceguera, dice que se ha hecho a sí mismo, no ha sido capaz de apreciar lo que los demás han hecho por él" 


\section{AGRADECIMIENTOS}


Quiero expresar en primer lugar mi más sincero agradecimiento al Profesor Doctor D. José Manuel Riesco Santos, de la Universidad de Salamanca, por su vinculación, dedicación y seguimiento como director de este trabajo de Tesis Doctoral así como su estimado apoyo familiar para que éste trabajo llegara a buen fin. Agradecimiento que hago extensivo a los Profesores Doctores D. Juan Antonio Juanes Méndez de la Universidad de Salamanca y al Profesor Dr. D. Alberto Prats Galino, de la Universidad de Barcelona, directores también de este trabajo de Tesis Doctoral, por su confianza, excelente predisposición, gran esfuerzo, y acierto en la ejecución de este proyecto informático para el estudio de las estructuras anatómicas de la vía óptica y aparato oculomotor.

Mi gratitud también sincera al Prof. D. Ricardo Vázquez Rodríguez, por su aceptación, seguimiento, su siempre buen humor, y por las facilidades prestadas en la unidad docente-investigadora que dirige, donde se ha llevado a cabo la mayor parte de este trabajo de Tesis Doctoral.

Especial mención y agradecimiento a Juan José Gómez Borrallo y a todo el personal técnico de la empresa Desarrollos Informáticos ABADIA, de Madrid, por la implementación de la aplicación informática.

A Olga Fuentes, del Departamento de Anatomía y Embriología Humana de la Facultad de Medicina de la Universidad de Barcelona, por su colaboración técnica. 
Mención y agradecimiento por el soporte económico necesario recibido a todos los implicados. Este desarrollo informático de la vía óptica y aparato oculomotor que presentamos ha contado con la financiación parcial del Instituto Alcon, además de formar parte de un proyecto subvencionado por la Generalitat de Catalunya (proyecto 2005MQD 00149) y la Universidad de Barcelona (proyecto 2005PID-UB/22), para el desarrollo de aplicaciones informáticas de carácter docente.

Deseo hacer extensiva mi gratitud a todos aquellos que de una forma $\mathrm{u}$ otra han colaborado en el desarrollo de esta Tesis Doctoral y sobre todo por la cesión de las imágenes radiológicas necesarias para la Tesis. Así, quiero resaltar la desinteresada colaboración de muchos radiólogos que nos han ayudado en la identificación de estructuras sobre las imágenes de resonancia magnética, tanto del Hospital Clínico de Barcelona como de la Santísima Trinidad de Salamanca. Agradecimiento especial en este sentido al Dr. Andrés Framiñán de Miguel, del Servicio de Radiodiagnóstico de la Fundación Hospital Santísima Trinidad de Salamanca.

A la Universidad de Salamanca como entidad, por haberme permitido ser una de sus afortunadas alumnas, y de la que siempre estaré orgullosa allá donde vaya.

Mi profundo agradecimiento a mi madre Piedad, por haberme incentivado cada día en el plano humano para entender que uno es antes persona que profesional y la importancia de estar al servicio de los demás así como por su aliento en los momentos difíciles para continuar con este proyecto, como en tantos otros proyectos de mi vida.

A mi padre Juan, por su tenacidad, voluntad y capacidad de trabajo que me ha servido de referente para mi carrera profesional y para impulsar proyectos como el de esta Tesis. Y a mi hermano Juanjo, que con 
su impresionante dominio de la informática y su don de gentes, me ha estado apoyando en todo momento haciendo más fácil la realización de múltiples proyectos de mi vida.

Y con mucho amor, a Enric, mi compañero de camino y apoyo en estos últimos meses de preparación y empujón final de la Tesis, por su aliento y motivación para la culminación de este proyecto y por dar sentido a un nuevo concepto de familia.

A todos, muchas gracias. 


\section{PRÓLOGO}


Tras terminar la carrera de Farmacia, decidí adentrarme en el mundo de la Empresa, a través de experiencias en diferentes laboratorios farmacéuticos, especialmente de ámbito internacional, donde he tenido la gran suerte de realizar un importante recorrido en diferentes posiciones de diferente grado de responsabilidad, incluidas las de Dirección.

Durante el desarrollo de mi carrera profesional, he podido experimentar gestionando diferentes equipos de personas, la importancia del lenguaje y las diferentes maneras de comunicarnos, las múltiples maneras de obtener resultados, las forma de relacionarnos con los demás, la importancia de brindar herramientas novedosas válidas y útiles según el cliente, el apoyo indiscutible que aportan los sistemas informáticos y sobre todo, la imperativa necesidad de formar adecuadamente a la gente.

Me pregunté si desde proyectos de investigación podrían cubrirse temas de necesidades formativas para así poder comenzar con alguna incursión en la investigación.

Gracias al Departamento de Anatomía e Histología Humanas de la Universidad de Salamanca, pude ponerme en contacto con diversos proyectos de investigación, uno de los cuales llamó especialmente mi atención y que encajaba paralelamente con mi visión del apoyo innovador, un proyecto de esfuerzo y cooperación interdisciplinar que ha culminado 
con el desarrollo de mi Tesis Doctoral: "Entono virtual de visualización 3D de la vía óptica y sistema oculomotor, a partir de secciones seriadas de Resonancia Magnética”

Para este trabajo se ha precisado de sistemas avanzados y de última generación en desarrollo y reconstrucción de imágenes informáticas, lo que me ha permitido ampliar conocimientos en otros terrenos cada día más presentes en cualquier actividad laboral.

Herramientas actuales donde se incide en las formas de aprendizaje tipo PNL (Programación Neuro Lingüística) enfatizan la importancia de utilizar los diferentes sistemas representacionales (visual, auditivo, cinestésico) para facilitar los mecanismos de aprendizaje. Este trabajo también me ha permitido incentivar aún más mi faceta docente en mi rol laboral actual como Coach Personal \& Ejecutivo.

Aunar investigación con necesidades de un sector profesional y docencia genera la satisfacción de poder dar servicio con optimización de recursos a los implicados: profesionales (oftalmólogos), profesorado y alumnos.

Espero y deseo que las aportaciones científicas realizadas en el presente trabajo puedan servir para el desarrollo de futuras líneas de investigación con entornos virtuales de visualización 3D. 


\section{INTRODUCCIÓN}


Los millones de neuronas localizadas en el cerebro reciben constantemente información que elaboran y procesan para, en muchos casos, tomar decisiones. Esta fuente de información está constituida principalmente por los sentidos. A su vez, el sistema nervioso central puede tomar la iniciativa y actuar sobre diversos órganos de los sentidos para regular su rendimiento.

Una gran parte de la información que recibe el cerebro humano procede del sistema de recepción visual. El sistema de información óptica está especializado en captar y procesar la información de las variaciones del campo electromagnético que se producen en nuestro entorno. Como otros sistemas sensitivos, el sistema visual crea un mapa con un código topográfico (visuotópico) de sus campos sensitivos, que forman el mundo visual y que mantiene en todos los niveles. La información luminosa se recibe por los fotorreceptores retinianos y el procesamiento inicial de las señales visuales se produce en la retina. Aunque esta estructura inerva diversas zonas diencefálicas y mesencefálicas, muchos axones retinianos terminan en núcleos de relevo talámicos que, a su vez, inervan una gran región de la corteza en el lóbulo occipital. Desde allí, la información visual es enviada a diversas regiones corticales que controlan gran parte de los lóbulos temporal y parietal. 
Todo este complejo sistema conductor y modulador de señales visuales constituye la vía óptica que se inicia en el globo ocular y que de forma muy sucinta, abordaremos desde tres enfoques diferentes: histórico, anatómico y ontogénico.

\section{Recuerdo Histórico.}

Fueron los egipcios, a través del papiro de Ebers, escrito unos 1550 años antes de nuestra era, los primeros en conocer y prestar atención a las enfermedades de los ojos. En él aparecen varias descripciones relacionadas con las afecciones oculares, pero siempre con cierto carácter misterioso (López Espinosa, 2007).

En cuanto a las primeras descripciones sobre la vía óptica que han llegado hasta nosotros proceden de Galeno, en el siglo II d.C. (Hernández González y col. 2002), quien describió los nervios ópticos como canales neumáticos transportadores de sensaciones desde los ojos al cerebro. Dichos canales comunicaban cada ojo con el correspondiente vestíbulo cerebral. Galeno describió una posible comunicación de ambos canales en la línea media formando una " $X$ ", pero creyó que se trataba de un mecanismo sustitutorio de visión que permitía conservar la visión binocular en caso de lesionarse uno de los ojos.

Otra obra con referencia internacional relativa al estudio de los ojos y de sus enfermedades, fue escrita en el siglo VI de nuestra era por el médico griego Aetius de Armida (502-575), donde se relacionan 61 afecciones oculares. 
Los médicos árabes introdujeron importantes avances en oftalmología durante la Edad Media. En el siglo IX, el médico árabe Abu Zayd Hunayn Ibn retoma los conocimientos galénicos pero insiste en la descripción del globo ocular. La primera representación del quiasma óptico (Fig. 1), en la que se muestra un entrecruzamiento real de las fibras ópticas se halla recogida en el libro de oftalmología del sirio Califa Ibn. Los médicos árabes además de

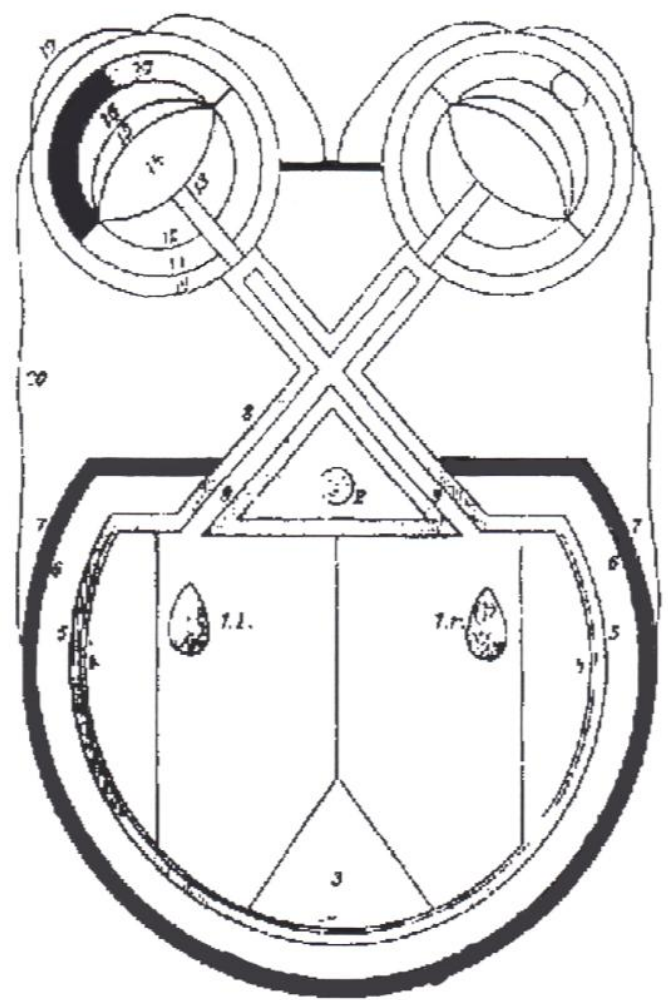
traducir la obra galénica, Figura 1.-.- Vía óptica según Califa Ibn (siglo IX). aportaron innovaciones en el conocimiento del globo ocular, del quiasma y del cerebro óptico. Entre las correcciones más interesantes a las descripciones galénicas están las relacionadas a la localización del cristalino, la concepción de la cámara posterior del ojo y la estructura del nervio óptico.

Fuera de la cultura islámica, la época medieval se limita a la transmisión de las obras grecolatinas y arábigas por lo que la llegada del Renacimiento y la invención de la imprenta significan un nuevo esplendor. El primer libro impreso sobre oftalmología fue De oculis eorumque egritudinibus et curis, en 1474 por el italiano Benbenuto Grassi, considerado como el cirujano de mayor celebridad entre los que durante la Edad Media se consagraron a la práctica de esta disciplina. 
La visión anatómica con más relieve en esta época se encuentra en la obra de Leonardo Da Vinci quien por primera vez dibuja un verdadero entrecruzamiento ratificando las aportaciones árabes sobre las fibras en el quiasma óptico. Sin embargo, Vesalio, medio siglo después en su obra $D e$ Humani Corporis Fabrica (1543) vuelve a dibujar al quiasma óptico no entrecruzado sino con una yuxtaposición de fibras (Fig. 2). En 1573, Varolio publica el primer libro dedicado al nervio óptico,

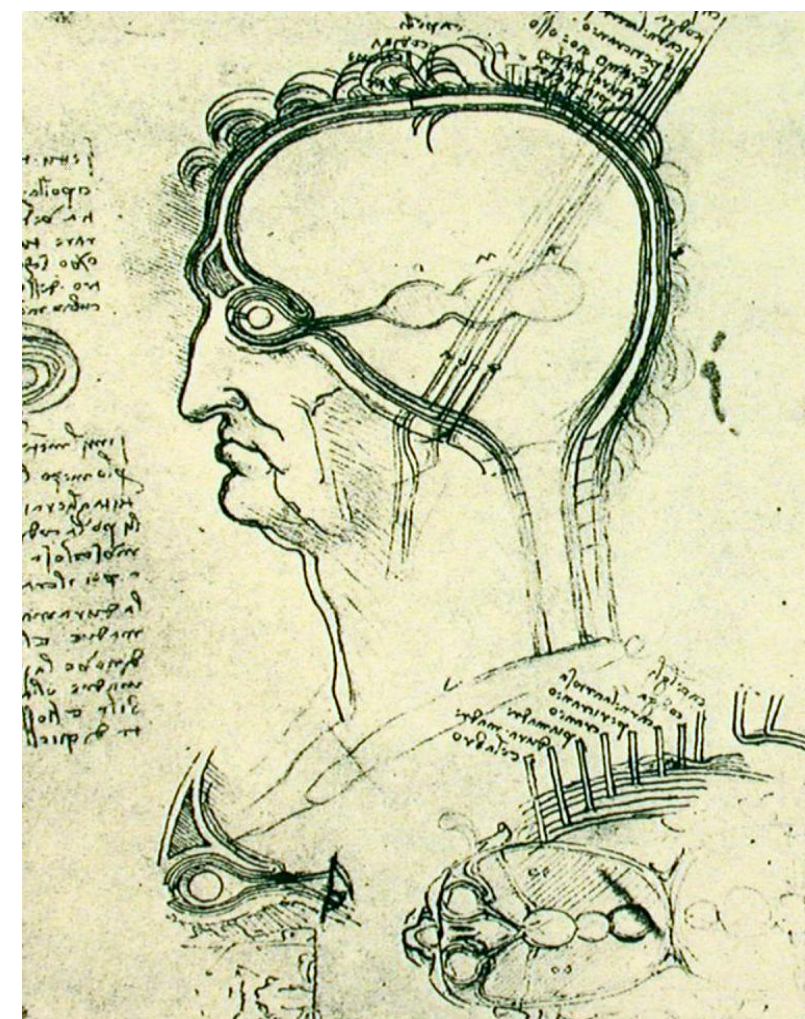

Figura 2.- Vía óptica según Vesalio. representando su origen talámico en la pared del III ventrículo. Este detalle ya había sido descrito por Eustaquio en 1551, pero no fue publicado hasta 1617.

Los conceptos galénicos persistieron hasta la mitad del siglo XVII y así Descartes (1596-1650) creyó en la representación mecánica de la visión y negó la existencia de una decusación quiasmática de los nervios ópticos. Según Descartes cada nervio óptico se originaba en un ventrículo lateral, continuándose por una ruta paralela al quiasma para terminar en la retina. Además se transmitía hacia la glándula pineal de forma separada desde cada ojo, antes de ser memorizado por el cerebro (Fig. 3).

El punto de comienzo de la concepción actual de la vía óptica se debe a un anglosajón, Willis, que en su tratado sobre Anatomía del cerebro (1644) demuestra que el nervio óptico no es un tubo hueco, como decía Galeno, sino una estructura maciza cuyo espesor está ocupado por fibras 
nerviosas. También observó y describió la continuación de la vía óptica hacia los tálamos y corteza.

Otros dos hechos deben ser considerados entre los primeros documentos que se enmarcan en la configuración moderna de la vía óptica. El primero, se debe a un estudiante de Medicina, Gennari quien en 1802 describe en la corteza cerebral calcarina un engrosamiento relacionado con la vía óptica, ratificado cuatro años después por Vicq d'Azyr y que se correspondería con la zona estriada del cortex descrito más tarde por Ramón y Cajal, debido a la

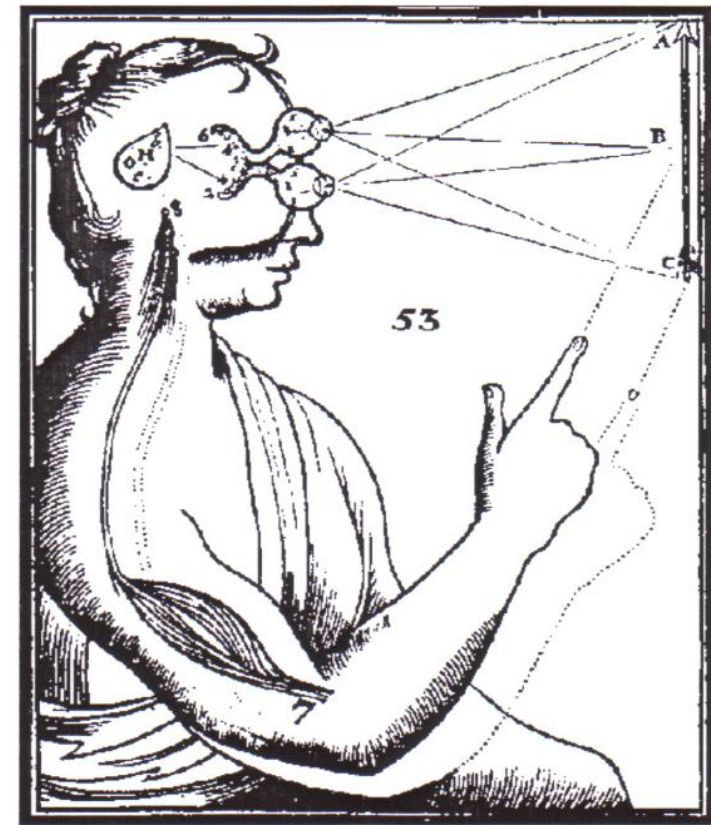

Figura 3.- Concepto de vía óptica según mielinización transversal de la cuarta capa cortical.

Finalmente, Gratiolet, en 1854, demuestra la continuación de la vía visual desde el tálamo hacia la corteza calcarina.

\section{Sinopsis anatómica de la vía óptica y del sistema oculomotor anejo.}

En esta sinopsis reseñaremos los datos más básicos de la anatomía de la vía óptica (Figs. 4 y 5) y del contenido orbitario, referido a los músculos extrínsecos del globo ocular y a los nervios que los animan (Fig. 6). Descripciones anatómicas detalladas pueden revisarse en textos clásicos de Anatomía Humana, Neurociencias y Monografías Oftalmológicas (Testut y Latarjet, 1969; Saraux y col., 1985; Amat, 1991; Saude, 1993; Nolte, 1994; 
Anatomía de Gray, 1998; Hubel 2000; Haines, 2003; Kaufman y Alm, 2007; Rouviere y Delmas, 2005; Purves y col., 2007; American Academy of Ophtalmology, 2008; Bear y col., 2008; Wilson-Pauwels y col.2003).

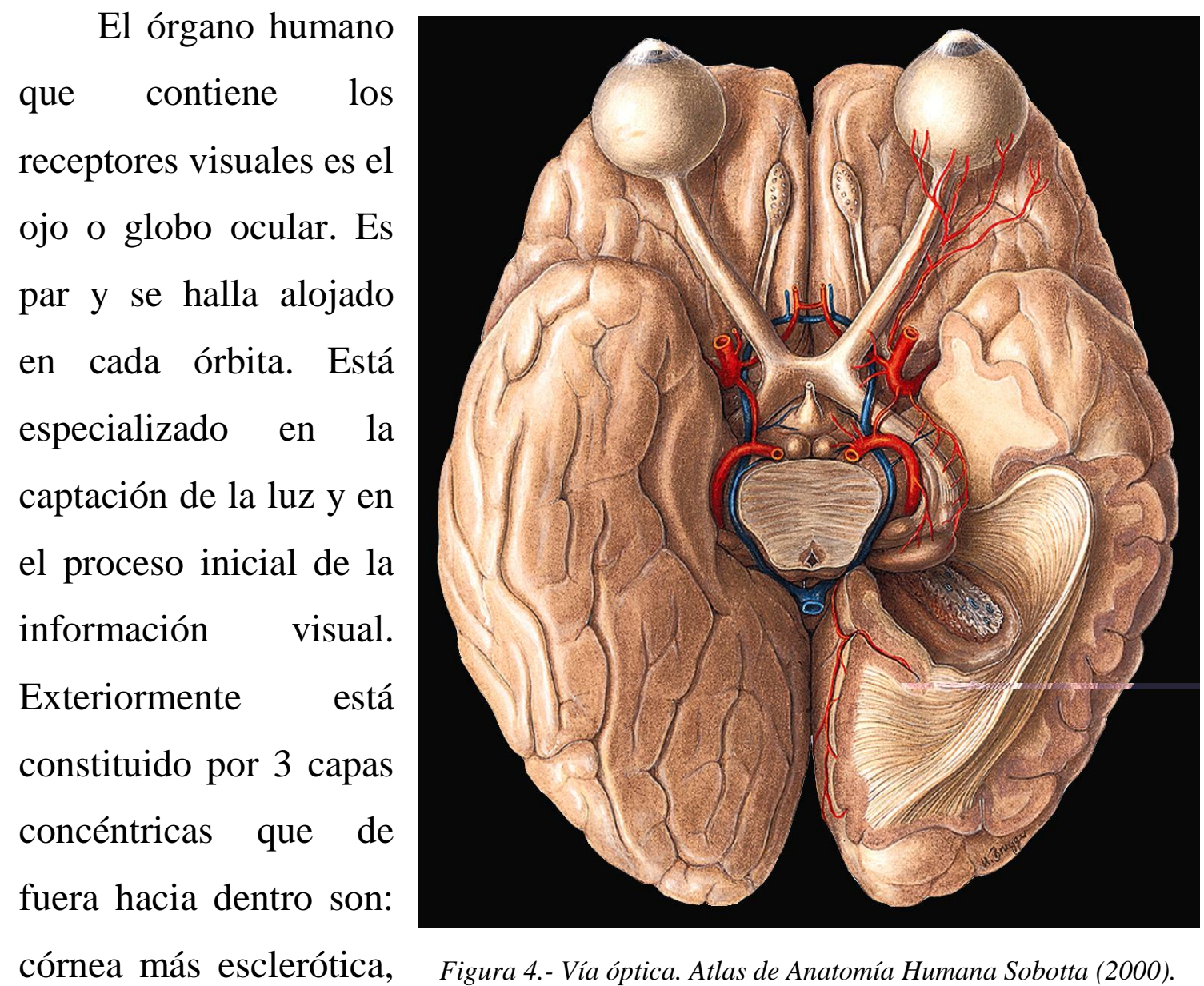
la úvea y la retina.

La córnea proporciona una capa protectora transparente y avascular para las estructuras ópticas del ojo. Su borde lateral se continúa con la conjuntiva y con la esclerótica, resistente y soporte de la inserción de los músculos estriados extraoculares.

La úvea constituye la túnica intermedia del ojo, eminentemente vascular e integrada por tres porciones: en la parte posterior, la coroides (tejido pigmentario muy vascularizado), en la porción media el cuerpo ciliar, que contiene los procesos ciliares donde se filtra el humor acuoso, y 
el músculo ciliar, liso; en la parte anterior, el iris que a manera de diafragma perforado (pupila) se sitúa por detrás de la cornea y por delante de una lente transparente, llamada cristalino, que enfoca la luz sobre la retina y está sujetada al cuerpo ciliar por el ligamento suspensorio o zónula de Zinn. El iris posee además musculatura intrínseca lisa que conforman los músculos: constrictor y dilatador de la pupila.

La capa más profunda de la pared ocular está formada por la retina que se compone de dos capas: la retina neural y el epitelio pigmentado retiniano. La retina neural contiene fotorreceptores y neuronas asociadas al ojo y está especializada en recibir la luz y en elaborar la formación resultante. Los fotorreceptores (conos y bastones) se encadenan con las células bipolares y éstas con las ganglionares, que constituyen las células de proyección de la retina ya que sus axones se reúnen para salir del ojo, por una pequeña área retiniana llamada papila o punto ciego, a partir de la cual se constituye el nervio óptico. En el cuadrante temporal de la retina, lateralmente a la papila, se halla la mácula, que corresponde al área de máxima agudeza visual y donde sólo hay conos.

Aparte de las paredes del globo ocular, existe un contenido que interviene en la función normal y patológica del ojo. Además del cristalino, ya reseñado, en el interior del ojo se hallan las cámaras anterior (entre córnea e iris) y posterior (entre iris y cristalino), comunicadas por la pupila y rellenas de humor acuoso que se reabsorbe en el ángulo irido-corneal a través del conducto de Schlemm. Entre el cristalino y la retina se sitúa la cámara vítrea que contiene al humor vítreo. 
Los nervios ópticos, procedentes cada uno de las células ganglionares de cada ojo, continúan la vía óptica, constituyendo el origen de las denominada Proyecciones Retinianas (Fig. 5), que si bien algunas llegan al diencéfalo (hipotálamo) y mesencéfalo (tubérculos cuadrigéminos, área pretectal), la inmensa mayoría terminan en el

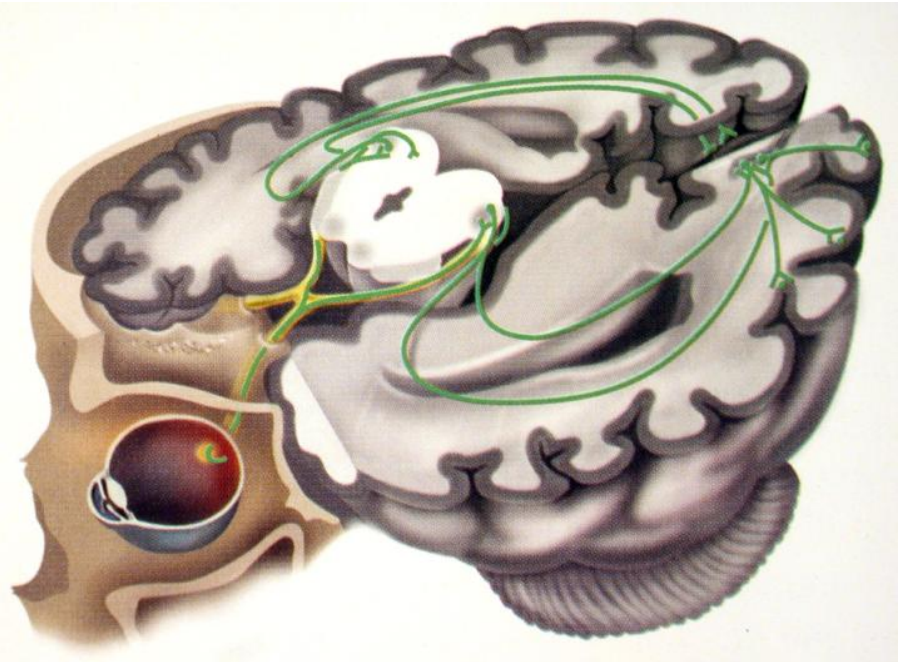

Figura 5. Vía óptica en un corte virtual 3D de la cabeza. Tomada de Wilson-Pauwels y col. 2003. núcleo geniculado lateral, por medio del nervio óptico, quiasma óptico y cintilla óptica.

El nervio óptico (Figs 4 y 5), se extiende desde el polo posterior del ojo, donde se encuentra la papila, hasta la porción rostral del tallo hipofisario, donde se une al del lado opuesto para formar el quiasma óptico del cual se bifurcan las cintillas ópticas para seguir su trayecto caudal. En el quiasma se cruzan las fibras ópticas procedentes de la mitad nasal de la retina mientras las fibras temporales prosiguen su recorrido por la cintilla óptica ipsilateral. Cada cintilla óptica finaliza en la porción ventral o base del núcleo geniculado lateral correspondiente, mientras de sus bordes laterales y dorsal parten las radiaciones ópticas que llegaran hasta la corteza visual primaria (corteza estriada, área 17 de Brodmann) situada en los labios superior e inferior de la cisura calcarina.

Las fibras de las radiaciones ópticas procedentes de la porción dorsomedial del núcleo geniculado lateral se incurvan directamente en sentido caudal para pasar a través del brazo retrolenticular de la cápsula 
interna y llegar a hacer sinapsis en la corteza del labio superior de la cisura calcarina, en el territorio conocido con el nombre de cuña.

Las fibras que se originan en la parte ventrolateral del núcleo geniculado lateral no viajan directamente en sentido caudal, sino que al salir del núcleo geniculado giran hacia arriba, entran en la sustancia blanca del lóbulo temporal y forman un amplio bucle en "U", llamado asa de Meyer o de Archambault, después siguen su camino posterior para hacer sinapsis en el labio inferior de la cisura calcarina, en la circunvolución lingual (Fig. 4). Las fibras geniculoestriadas que transportan información desde la mácula llegan a las zonas caudales de de la corteza visual primaria

La vía óptica macroscópica termina en torno a la cisura calcarina. No obstante, desde esta corteza primaria la información visual pasa a otras áreas corticales como la corteza periestriada (área 18 de Brodmann) y paraestriada (área 19) así como a otros territorios corticales distribuidos principalmente por los lóbulos temporal y parietal, de gran importancia para el procesamiento y la percepción del espacio visual.

Los animales utilizan sus órganos de los sentidos para examinar el entorno en busca de información. Esta conducta de

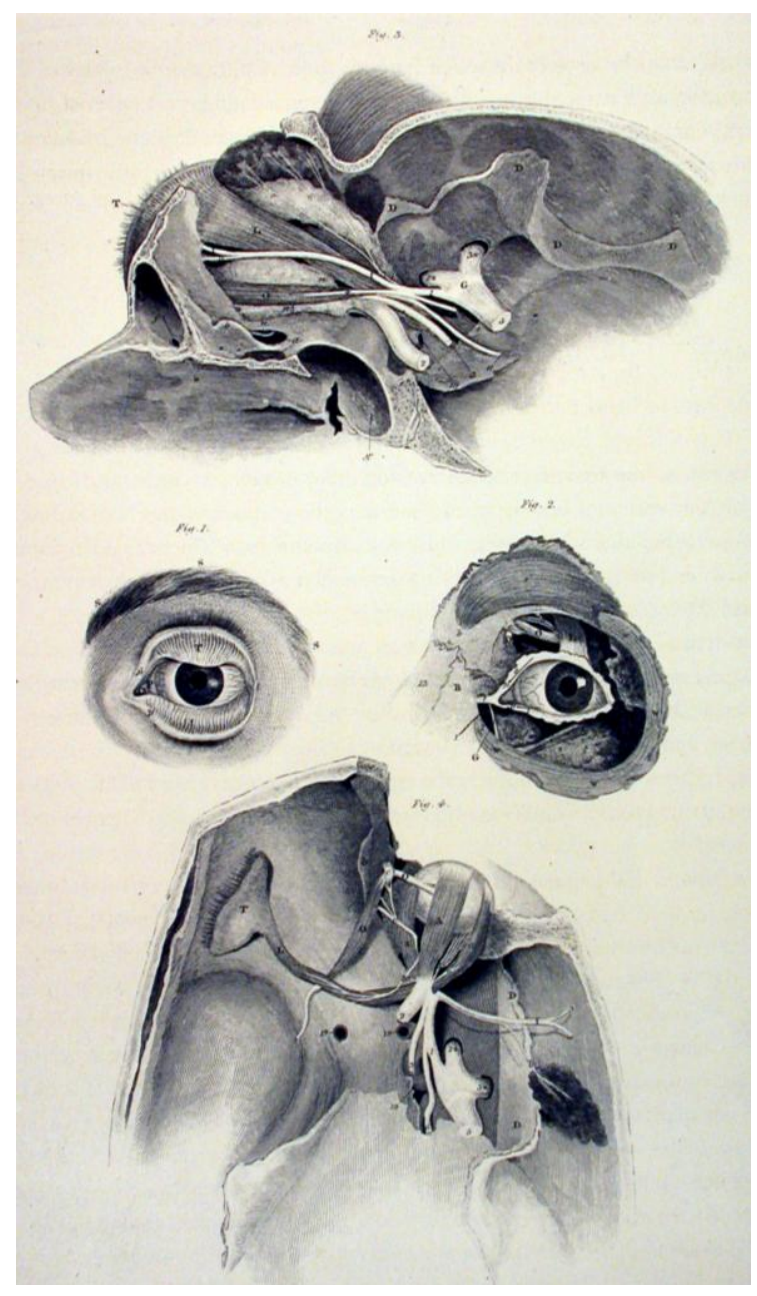

Figura 6.-Contenido orbitario. Plancha X, parte $I X$, de la obra aparecida en 1825: "A system of anatomical plates of the human body", de J. Lizars (1787-1860). 
adaptación la presentan todas las criaturas, desde las abejas hasta los seres humanos. En éstos quedaría muy limitada la función sensorial de captación y reconocimiento de imágenes si hubiese que mover constantemente la cabeza para dirigir el inicio de la vía óptica hacia la inmensidad del campo visual. Por eso, lo ojos están dotados de sistemas neuromusculares cuya acción provoca movimientos que consienten la inspección cuidadosamente del entorno, cuando es necesario. Además, en la especie humana, el movimiento ocular permite dirigir la mácula hacia los objetos de interés, lo que representa una conducta adaptativa crucial para el ser humano. En estos sistemas neuromusculares, los músculos estriados extraoculares orientan nuestros ojos, extremadamente móviles, y el sistema nervioso oculomotor sirve para controlarlos.

El ojo se mueve dentro de la órbita mediante seis músculos extraoculares (Figs. 6 y 7 ) que producen movimientos en el plano horizontal (hacia la izquierda y la derecha), alrededor de un eje vertical (hacia arriba y hacia abajo), en torno a un eje horizontal y movimientos de torsión (en los sentidos horario y antihorario) sobre un eje que va desde la pupila hasta la mácula. Existen dos pares de músculos rectos y otro par de oblicuos. Para los movimientos oculares horizontales, el músculo recto medial rota el ojo hacia la nariz (aducción) y el recto lateral,

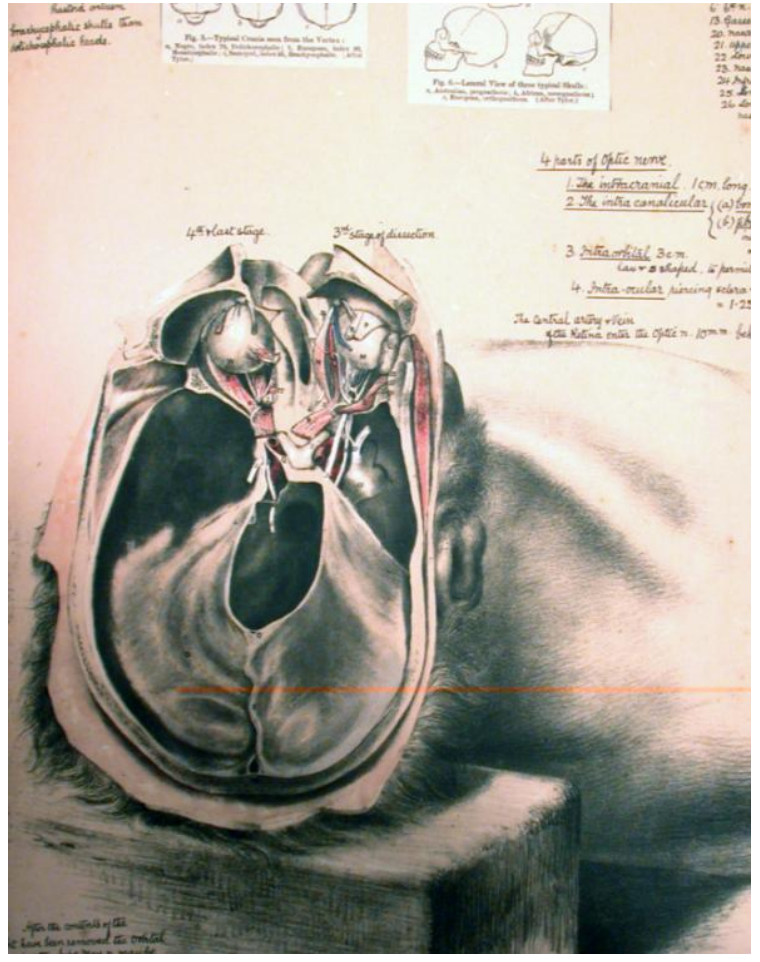

Figura 7.- Contenido orbitario visto desde la fosa craneal anterior, con especial referencia a los músculos y nervios, según el anatomista Georges V. Ellis (1812-1876) y plasmado por el dibujante George H. Ford (1809-1876). 
lo rota hacia la región temporal (abducción). En los movimientos verticales, el músculo recto superior (Fig. 6) rota el ojo hacia arriba (elevación), en sincronismo con un séptimo músculo extraocular, llamado elevado del párpado superior, mientras que el músculo recto inferior rota el ojo hacia abajo (depresión). De los dos músculos extraoculares oblicuos, el superior (Fig. 7), provoca rotación interna, depresión y abducción, mientras el inferior se encarga de la rotación externa, elevación y abducción.

Los músculos extrínsecos del ojo están inervados por tres nervios o pares craneales (Figs. 6 y 7). El nervio abducens (VI par craneal) se hace cargo del músculo recto lateral, el nervio troclear (IV par) controla al músculo oblicuo superior y los músculos restantes están inervados por el nervio oculomotor (III par).

\section{Ontogenia de la vía óptica.}

Una ayuda substancial en el conocimiento anatómico de órganos, aparatos y sistemas se obtiene analizando su desarrollo embrionario. Por eso, es importante describir los puntos fuertes de su ontogénesis para conocer y comprender mejor la vía óptica.

El desarrollo precoz del ojo y de sus estructuras anejas se debe a una serie de señales inductoras que junto con factores de crecimiento y genes que contienen homeosecuencias, como el regulador de la transcripción Pax6, intervienen decisivamente en el desarrollo molecular del ojo (Barnstable, 1987; Mathers y col., 1997; Larsen, 2003; Moore y Persaud, 2008).

El ojo deriva a partir de cuatro orígenes distintos: a) del neuroectodermo perteneciente al encéfalo anterior (prosencéfalo); b) del ectodermo de la superficie cefálica; c) del mesodermo existente entre las 
capas anteriores y, d) de las células de la cresta neural. Del neuroectodermo se diferenciará la retina, las capas posteriores del iris y el nervio óptico. El ectodermo de superficie formará el cristalino y el epitelio corneal. El mesodermo origina las cubiertas fibrosas y vasculares del ojo y las células de la cresta neural emigran al mesénquima procedente del mesodermo y se diferencian en coroides, esclerótica y endotelio corneal.

El desarrollo del ojo empieza a manifestarse en el embrión humano a principios de la cuarta semana (O’Rahilly, 1966, 1975; 1983; Wright, 1997; Larsen, 2003; Sadler, 2006; Kaufman y Alm, 2007; Moore y Persaud, 2008), en los pliegues neurales del encéfalo anterior, bajo la forma de dos fisuras laterales denominadas surcos ópticos. Cuando los pliegues neurales se fusionan y forman el prosencéfalo, los surcos ópticos se evaginan y crecen en dirección al ectodermo de superficie. En su porción distal se dilatan y forman las vesículas ópticas (Figs. 8 y 9). Cuando las vesículas ópticas contactan con el ectodermo de superficie, se inducen cambios que afectan a las zonas de contacto; así, aparece un
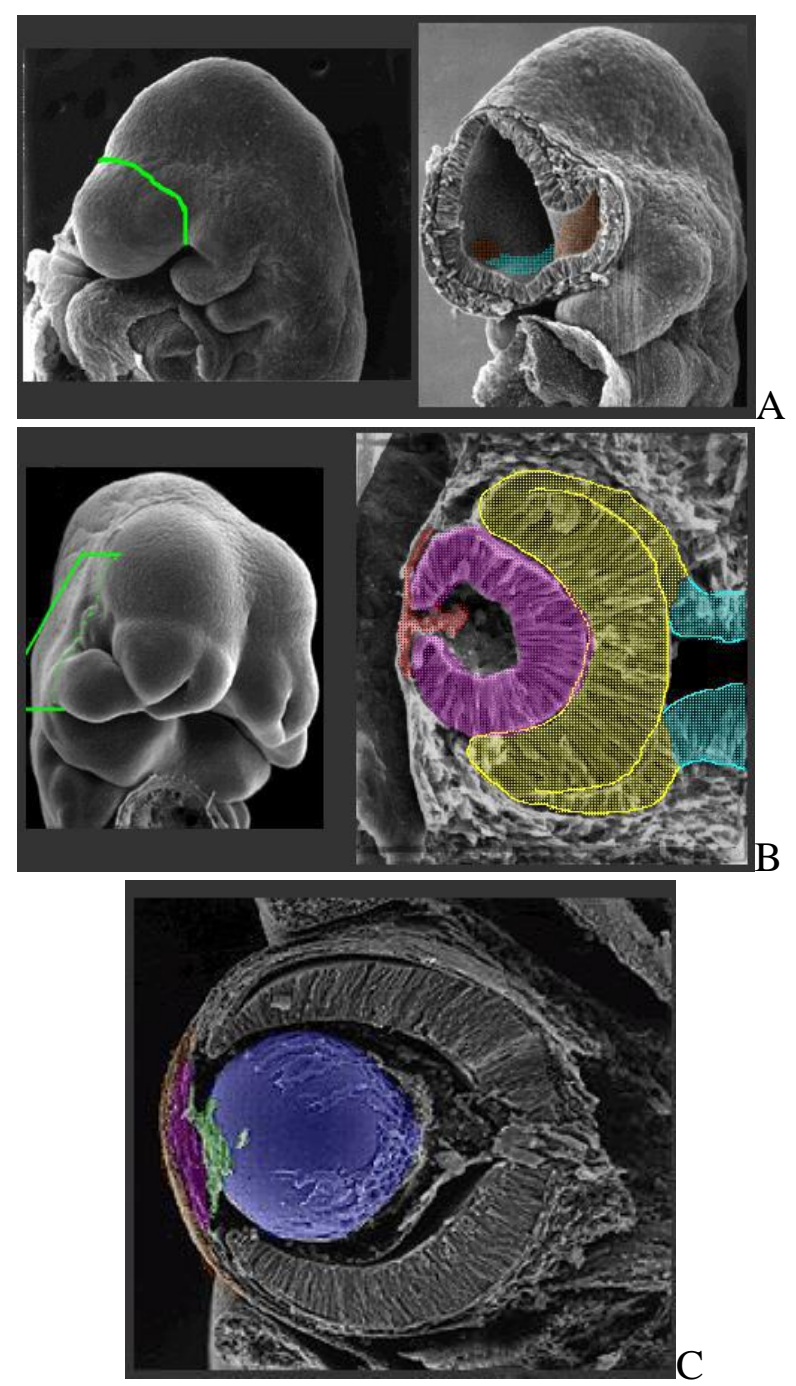

Figura 8. Microscopia electrónica de barrido del desarrollo inicial: del ojo (a); del hundimiento de la vesícula cristaliniana (b) y de las capas oculares (c). 
engrosamiento ectodérmico que forma la placoda del cristalino y en la vesícula óptica se hunde su cara distal, o disco retiniano, transformando la vesícula en cúpula o cáliz óptico que queda unido al encéfalo anterior por un pedículo estrecho y hueco llamado tallo óptico (ver figuras 8 y 10). A su vez, la placoda cristaliniana se invagina y pierde contacto con el ectodermo para convertirse en la vesícula del cristalino, hueca y localizada en el interior del cáliz óptico.

Para llegar a convertirse en el cristalino sólido del ojo, las células posteriores de la vesícula cristaliniana se alargan y estrechan para orientarse en el eje antero-posterior y formar las fibras primarias del cristalino (Mc Avoy y col., 1999). Las células anteriores constituyen un revestimiento monoestratificado de la superficie del cristalino del que derivarán, a partir de la octava semana del desarrollo, las fibras secundarias del cristalino que formaran la mayor parte del cristalino maduro (ver figura 8). En la actualidad

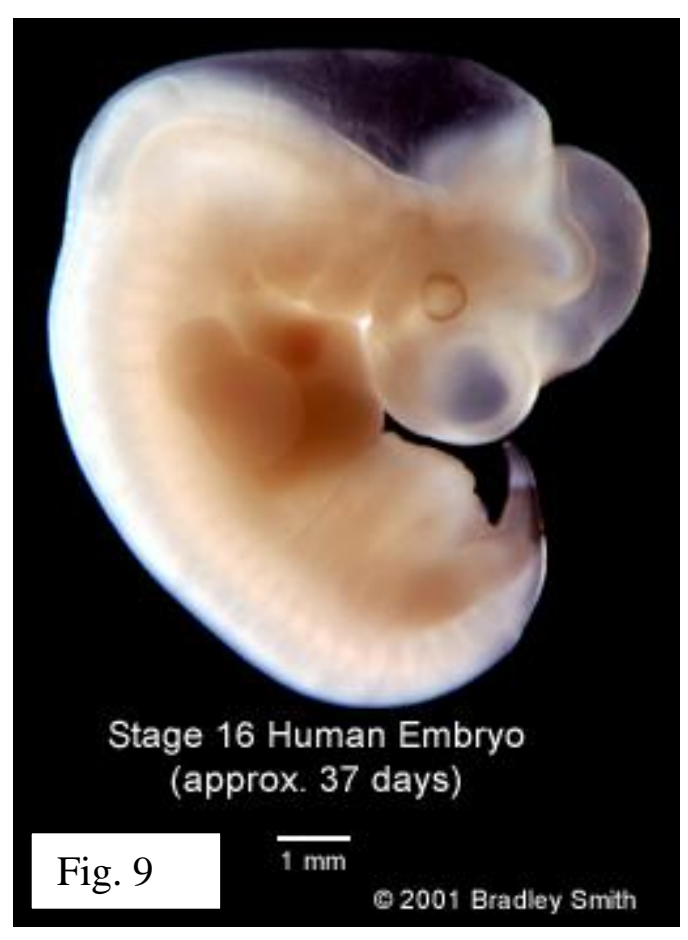
se discute si la inducción de la placoda del cristalino es debida a la formación del cáliz óptico (Saha y col., 1989; Tam, 1989; Larsen, 2003), pero al menos varios experimentos indican que el cáliz óptico influye en el crecimiento, diferenciación y mantenimiento de cristalino. El espacio que queda entre cáliz óptico y vesícula cristaliniana se rellena de una matriz gelatinosa denominada cuerpo vítreo primario.

En el cáliz óptico, la superficie interna da lugar a la retina neural mientras que la pared externa forma la retina pigmentaria que contiene 
melanina (Fig. 10). Entre ambas capas existe, durante el periodo embrionario y fetal temprano, un espacio intrarretiniano que poco a poco se va obliterando en el desarrollo ulterior. La capa interna del cáliz óptico prolifera y forma un neuroepitelio grueso que más tarde se diferencia en retina neurosensorial o región fotosensible de la porción óptica de la retina, que contiene los fotorreceptores (conos y bastones) y las células bipolares y ganglionares. Debido a la invaginación de la vesícula para forma el cáliz óptico, la retina neurosensorial se halla "invertida" de forma que las células fotorreceptoras se hallan junto al

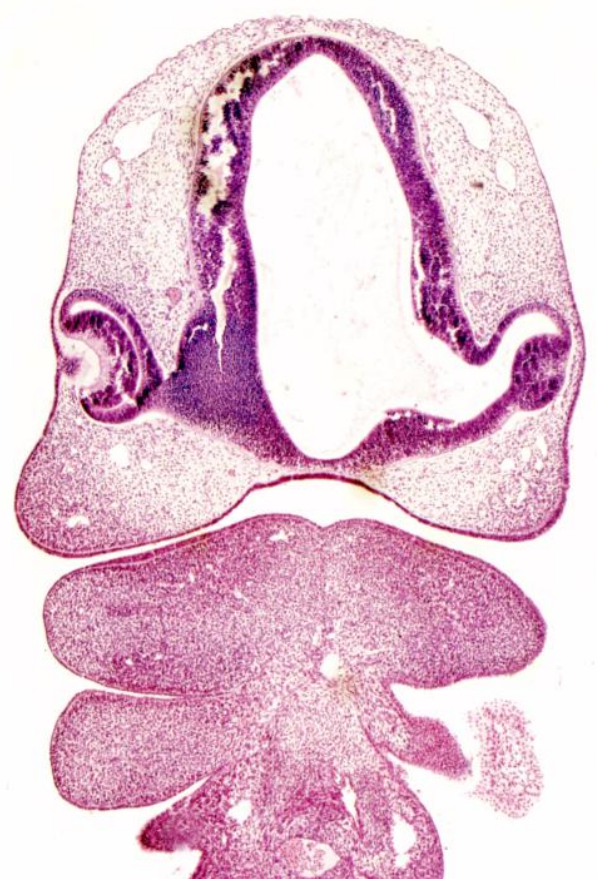

Figura 10.- Corte transversal cefálico de un embrión de $6 \mathrm{~mm}$ perteneciente al Dpto. de Anatomía e Histología de la USAL, con el cáliz óptico abrazando a la vesícula cristaliniana y el pedículo óptico partiendo del diencéfalo epitelio pigmentario retiniano, por lo que la luz debe atravesar la parte más gruesa de la retina antes de incidir sobre los fotorreceptores.

Los axones de las células ganglionares situados en la capa superficial de la retina neurosensorial crecen siguiendo el pedículo óptico hasta el cerebro. Por eso, la cavidad inicial del pedículo óptico se va obliterando progresivamente y transformándose, a partir de la octava semana en nervio óptico (II par craneal). Antes de entrar en el cerebro, los dos nervios ópticos se unen en X para formar el quiasma óptico (Fig. 11), donde aproximadamente el $50 \%$ de las fibras de cada nervio óptico se cruzan al lado opuesto del cerebro. El haz combinado resultante de fibras homo y heterolaterales en cada lado sigue su camino hacia el cuerpo geniculado 
lateral del tálamo, donde comienza la sinapsis nerviosa a partir de la octava semana.

En la superficie ventral del pedículo y del cáliz óptico se forman unos surcos lineales llamados hendiduras retinianas que contienen mesénquima vascular a partir del cual se forma la arteria y la vena hialoidea que llevan y drenan sangre a la capa interna del cáliz óptico, vesícula cristaliniana y mesénquima de la cavidad del cáliz óptico. Cuando se fusionan los bordes de la hendidura retiniana, los vasos hialoideos quedan incluidos dentro del nervio óptico primitivo. Las partes distales de estos vasos degeneran mientras las proximales persisten como arteria y vena central de la retina.

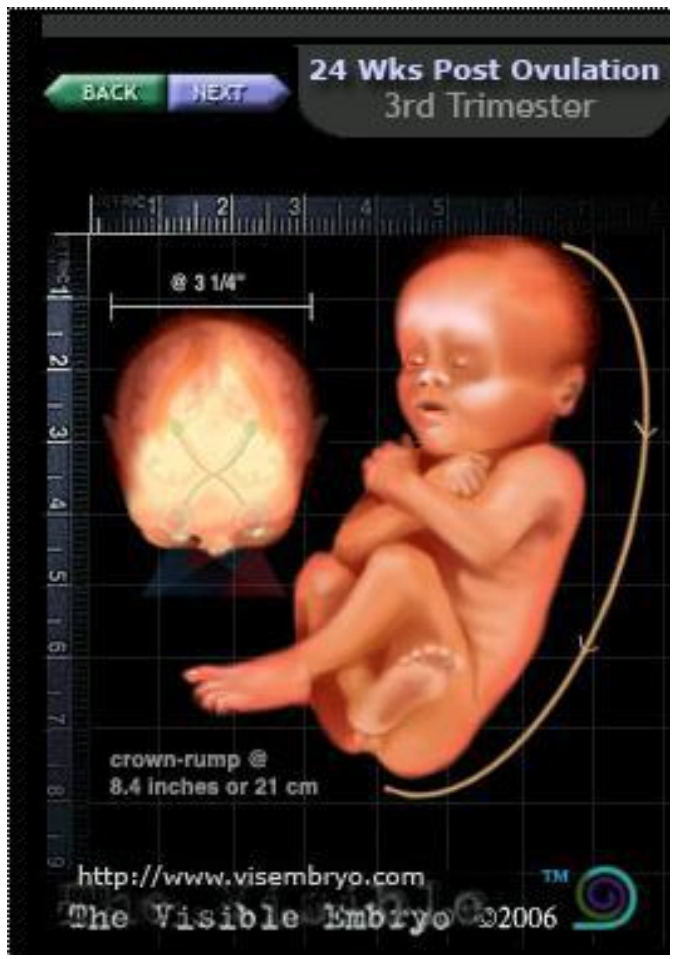

Figura 11.- Feto de 24 semanas de la colección Visible Embryo, mostrando por transparencia la vía óptica.

Mientras se forma la vesícula óptica (Fig. 12), se va rodeando de una capa de mesénquima, en parte colonizado por células de la cresta neural, que se diferencia para formar las dos capas excéntricas a la retina, esto es: la fina coroides y, más externa, la fibrosa capa escleral. Este mesénquima también crece y, a finales de la sexta semana, reviste la superficie anterior del ojo en desarrollo, incluido el cristalino. Concretamente, el mesénquima que cubre al cristalino se divide durante la séptima semana en dos capas que encierran un nuevo espacio denominado cámara anterior. La pared externa de la cámara anterior se continúa con la esclerótica del globo ocular y la pared interna se continúa con la coroides. 
La pared externa de la cámara anterior da lugar a las capas internas de la córnea mientras que la capa externa de la córnea deriva del ectodermo superficial cefálico (Sevel e Isaacs, 1988). La pared interna de la cámara anterior, que se halla cubriendo al cristalino, se denomina membrana pupilar. Las capas profundas de esta pared sufren vacuolizaciones hasta llegar a crear un nuevo espacio llamado cámara posterior, que queda entre el cristalino y la membrana pupilar, la cual, a principios de la era fetal, se rompe por completo para dar lugar a la pupila.

A finales del tercer mes del desarrollo, el borde anterior del cáliz óptico y el mesénquima coroideo que lo recubre se expande para formar un fino anillo interpuesto entre las cámaras anterior y posterior del ojo. Este anillo da lugar al iris. La
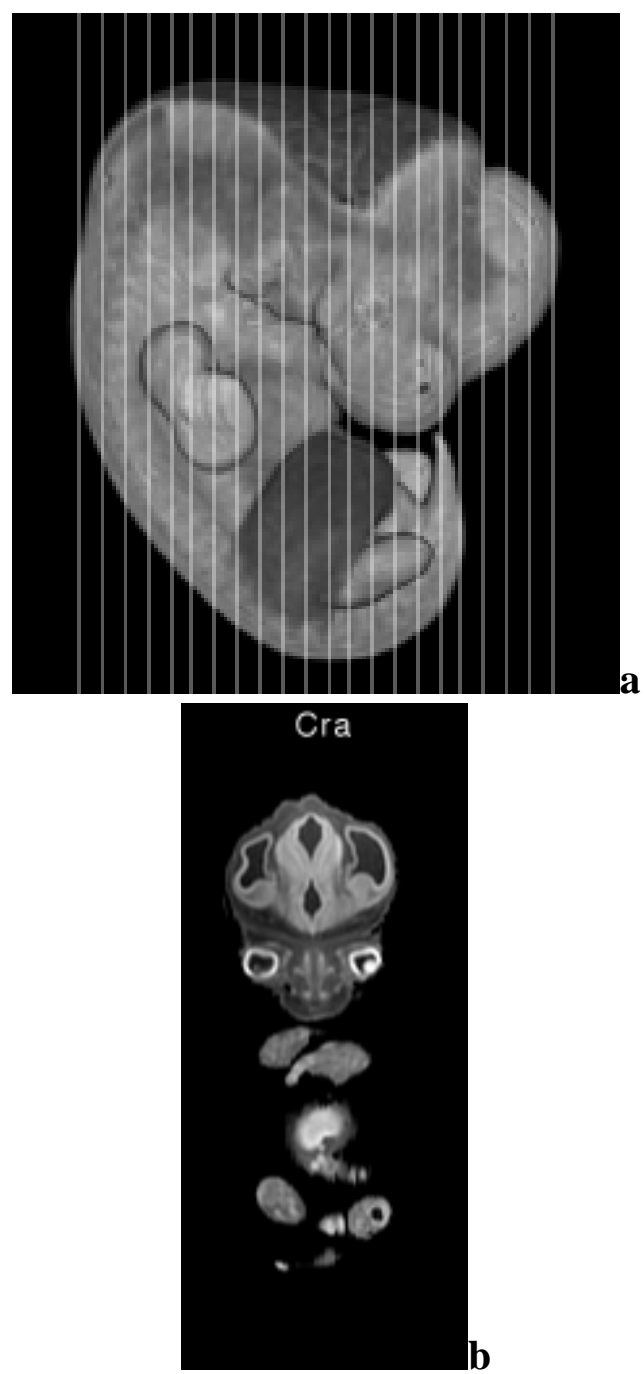

Figura 12.- a: Superficie de un embrión humano (estadio 16 de la Carnegie; 37 días postovulación) con los planos de corte de MRM; b: corte coronal de RM que interesa los globos oculares v el cristalino. superficie interna está revestida por un fino epitelio resultado de la fusión de las dos capas retinianas; el resto del iris procede del mesodermo coroideo. En el espesor del iris y partir de células de la cresta neural, se constituye un músculo liso denominado esfínter pupilar, que actúa a manera de diafragma, controlando el diámetro de la pupila y la cantidad de luz que entra en el ojo. 
Por detrás del iris, el cáliz óptico y la coroides se diferencian para formar el cuerpo ciliar (Sellheyer, 1990), eminentemente vascular pero en el que además se forma una red radial de fibras elásticas que se fijan al ecuador del cristalino en formación, constituyendo la zónula o ligamento suspensorio del cristalino. Alrededor de las inserciones de estas fibras, el epitelio del cáliz óptico en contacto con la coroides prolifera y da lugar a los procesos ciliares, especializados en la secreción del humor acuoso. Además, células derivadas de la cresta neural que colonizan la coroides del cuerpo ciliar se diferencian para formar haces de musculatura lisa que configuran el músculo ciliar, destinado a controlar la acomodación del cristalino.

El mesodermo adyacente al globo ocular se diferencia en las semanas quinta y sexta para formar los músculos oculares extrínsecos. Los primeros que aparecen son los músculos rectos superior y externo (lateral). Después aparece el músculo oblicuo superior, seguido del recto interno (medial) y del esbozo común del recto inferior y oblicuo inferior. No es hasta el inicio de la octava semana cuando surge el elevador del párpado superior, como delaminación del músculo recto superior, y la polea o tróclea del oblicuo superior. Sigue estando confuso el origen del mesodermo que origina los músculos oculares extrínsecos; hay datos que sugieren como origen al mesodermo paraaxial y otros, que lo asignan a la placa procordal (Watchtler, 1984). Por lo general, hay acuerdo en que los componentes del tejido conectivo de los músculos oculares extrínsecos derivan de la cresta neural (Larsen, 2003; Sadler, 2006; Moore y Persaud, 2008; Rohen y Lütjen-Drecoll, 2008; Noden, 1983).

Los nervios o pares craneales que inervan a los músculos extraoculares alcanzan la vecindad del ojo en desarrollo durante la quinta semana del desarrollo, a principios de la quinta semana lo hace el III par 
(nervio oculomotor) mientras que los pares IV (troclear) y VI (abducens) lo hacen a finales de la misma semana.

Como estructuras asociadas a los ojos, se encuentran los párpados que se forman, durante la sexta semana, a partir de pliegues de la superficie ectodérmica y del mesénquima asociado. Estos esbozos palpebrales superior e inferior crecen rápidamente uno hacia el otro, fusionándose en la octava semana, para volverse a separar entre el quinto y séptimo mes.

El espacio situado entre los párpados fusionados y la cornea se denomina saco conjuntival y es un derivado ectodérmico. En su ángulo supero-lateral se forman unas invaginaciones ectodérmicas que originan las glándulas lagrimales, aunque su maduración no sea hasta 6 semanas después del nacimiento. Las lágrimas se excretan al saco conjuntival y después de lubricar la córnea son drenadas hacia la cavidad nasal a través del conducto nasolagrimal, el cual se forma a partir de un cordón macizo constituido en el surco nasolagrimal, entre los procesos maxilares y los nasales laterales, que tras recanalizarse y ensancharse en su porción superior (saco lagrimal) une el ángulo interno del ojo con el meato inferior de la cavidad nasal.

\section{Técnicas de diagnóstico por imagen para el estudio de la vía óptica.}

La Tomografía computarizada y, sobre todo, la Resonancia Magnética de alto campo o de alta resolución han revolucionado la comprensión e interpretación de las estructuras anatómicas encefálicas, al poder obtener secciones seriadas, lo que ha supuesto un gran avance en el diagnóstico por métodos no invasivos o mínimamente invasivos. 
Con estas técnicas se han estudiado patologías orbitarias, incluidas la glándula y vías lagrimales, los párpados y el contenido vásculonervioso (DePotter y col., 1993; Hernández González y col., 2003; Mercader y Viñuela, 2004), la patología de los músculos extrínsecos del ojo (Rubí y col., 2002; Aoki y col., 2003; Hoerantner y col., 2007; Lennerstrand, 2007; Ela-Dalman y col., 2008) y las alteraciones en la vía óptica, desde el globo ocular hasta la corteza occipital (Tamraz, 1994; Tamraz y col., 1999; Villablanca y col., 2000; Alberico y col., 2004).

A continuación describiremos los principios físicos básicos en los que se basan estas dos técnicas.

\section{Tomografía Computarizada (TC)}

La TC es un tipo especial de procedimiento radiológico que implica la medición indirecta de la atenuación de los rayos $\mathrm{X}$ en numerosos puntos localizados alrededor del objeto o paciente explorado.

La imagen de una TC es una matriz cuadriculada de elementos que reciben el nombre de pixels. Cada pixel representa un pequeño elemento de volumen (voxel) dentro de una sección o corte imaginario de la región corporal explorada. Mediante el computo de varias series de determinaciones recogidas por el tomógrafo computarizado se obtiene el coeficiente de atenuación lineal medio de rayos $\mathrm{X}$ que se compara con el valor de atenuación del agua, el cual por definición es 0 y así se asignan unidades que van desde -1.000 (coeficiente del aire) hasta +1.000 (coeficiente próximo al hueso). Esta escala de coeficientes de atenuación recibe el nombre de escala de Hounsfield y está constituida por 2.000 unidades, cada una de las cuales se llama unidad Hounsfield o número TC. A cada unidad se le asigna un valor de tonalidad gris relacionado de forma 
lineal con su magnitud. Así, estructuras de alta atenuación se muestran en blanco y las de baja en negro. La imagen de TC es un mapa de la distribución espacial de los coeficientes calculados de atenuación radiológica.

La resolución de las imágenes de TC está relacionada al tamaño de la matriz de la imagen respecto al área representada (campo de visión). Las matrices suelen oscilar entre 128 x 128 y 1024 x 1024, siendo la más utilizada la de 512 x 512, es decir 262.000 pixels. Si se reduce la resolución (los pixels), también desciende la señal de cada pixel y la proporción entre señal y ruido. Por eso, si se quiere mejorar la resolución ante la disminución del pixel habrá que aumentar el tiempo de la muestra o la tasa de dosis.

Como el ojo humano no puede discriminar más de 20 tonos en la escala de grises, cada tono de gris en la imagen TC está constituido por varias unidades Hounsfield (anchura de ventana) y el valor central de la ventana recibe el nombre de nivel. Todos los vóxels con un número TC mayor que el límite superior de la ventana se visualizarán en blanco y todos los inferiores en negro. Es importante tener presente que el número TC de un vóxel y el tono de gris derivado del pixel correspondiente se determinan por la atenuación media en ese vóxel. Ello implica que las dimensiones de una estructura pueden estar distorsionadas, especialmente en las zonas en las que confluyen tejidos con número TC muy diferentes, por ejemplo hueso y cerebro. Estas distorsiones de dimensiones en las imágenes de TC reciben el nombre de efectos de volumen parcial y son más pronunciadas cuanto mayor es el grosor de los cortes.

Con el fin de destacar ciertas estructuras de las vecinas, se suelen emplear contraste radiológico que aumentan o reducen el coeficiente de 
atenuación de los rayos $\mathrm{X}$ de un tejido u órgano, con lo que aumentan el contraste positivo o negativo con respecto a su entorno. Generalmente las exploraciones con TC de sistema nervioso, columna vertebral y sistema musculoesquelético no requieren administración de contrastes.

Avances importantes en los últimos años son los tomógrafos helicoidales multicortes y los constituidos por varias coronas de detectores. Junto a este desarrollo tecnológico se ha incrementado la velocidad de giro del conjunto tubo-detector y todo el proceso informático de manejo de datos para la elaboración de la imagen. Con estos avances se acorta notablemente el tiempo de exploración y se mejora la resolución espacial, permitiendo obtener un vóxel de exploración iso-volumétrico, con lo que es posible realizar un postproceso de la imagen en cualquier plano del espacio sin pérdida de resolución (Fraile Moreno, 2007).

\section{$\underline{\text { Resonancia Magnética }(\text { RM) }}$}

A diferencia de la TC, la RM emplea la radiación no ionizante de una banda de radiofrecuencia (RF) del espectro electromagnético. Las imágenes basadas en la RM combinan un potente campo magnético generado por un gran electroimán y una energía de radiofrecuencia (RF) para estudiar la distribución y el comportamiento de los protones de hidrógeno en el tejido adiposo y el agua.

Los principios o bases físicas de la RM estriban en las propiedades magnéticas del átomo. Los núcleos atómicos giran en torno a sus ejes y las partículas nucleares (protones y neutrones) poseen cada uno un spin o momento angular. En aquellos núcleos con partículas nucleares en equilibrio, el espín de cada partícula anula al de otra, lo que hace que el espín neto sea cero. Sin embargo, en los núcleos que contengan un protón o 
neutrón no pareado, se creará un espín neto. Como el espín se asocia con una carga eléctrica, se generará un campo magnético en los núcleos con partículas nucleares no pareadas y dichos núcleos se comportarán como pequeños imanes con polos norte y sur (dipolos magnéticos).

El núcleo del hidrógeno contiene un único protón no pareado y por eso se comporta como un dipolo magnético. En una muestra con muchos átomos de hidrógeno, se encontrarían estos dipolos magnéticos orientados al azar y la magnetización total resultante sería cero. Pero si se aplica un campo magnético externo a la muestra, todos los ejes de los núcleos de hidrógeno se alinean siguiendo la dirección del campo magnético, lo que da lugar a una cantidad neta de magnetización con dos estados de espín posibles: espín paralelo al campo magnético y espín antiparalelo, los cuales contienen cantidades de energía diferentes. La energía requerida para pasar de un estado de menor a mayor energía puede aportarse o recuperarse en forma de energía electromagnética en la zona de RF del espectro electromagnético. A la transición de un nivel de energía a otro se la denomina resonancia.

Al aplicar un campo magnético externo a una muestra de núcleos, sus polos no se alinean exactamente con la dirección del campo magnético sino que los ejes de los protones giratorios se desplazan con un cierto ángulo. Este movimiento angulado u oscilante recibe el nombre de precesión. Al ritmo o frecuencia de precesión se le denomina frecuencia de resonancia o Larmor; depende del tipo de núcleo y es proporcional a la fuerza del campo magnético externo.

En los tejidos, la resultante longitudinal de la imantación es paralela al campo magnético. La resultante transversal, por el contrario, es nula, es 
decir, los espines no están en fase en el plano perpendicular al campo magnético.

En la aplicación de campos magnéticos para la obtención de imágenes de RM hay que tener en cuenta dos fases:

a) Fase de excitación, con la emisión de pulsos de RF. La interacción entre una onda de RF emitida con los espines de precesión, hace resonar los tejidos. La transferencia de energía ocurre solo si la onda de RF tiene la misma frecuencia que los espines. En este proceso, ocurre una disminución de la componente longitudinal y un aumento de la componente transversal. La primera se debe a un cambio en la orientación de los espines, al estado de mayor energía (antiparalelo). La segunda se debe a una puesta en fase de los espines en el plano perpendicular al campo magnético.

b) Fase de decaimiento energético: recepción de pulso de RF. Cuando se deja de emitir onda de radio (pulso de RF de resonancia) ocurren dos acontecimientos: la radiación de energía y el retorno de los núcleos a su estado de espín original de menor energía. A este proceso se le denomina relajación y la energía perdida es detectada como una señal llamada caída de inducción libre.

El retorno al equilibrio de la imantación tisular produce una emisión de una onda de RF que es la señal registrada en la RM por la antena de RF. Las constantes de tiempo de la señal son características de los distintos tejidos y las que dan el contraste de la imagen. Los diferentes tipos de contrastes en las imágenes de RM se obtienen variando los tiempos entre pulso RF y la medición.

De acuerdo con estas bases físicas para obtener imágenes de RM se somete al paciente a un campo magnético intenso, homogéneo y estable en 
el tiempo. Con ello se consigue que los momentos magnéticos de los núcleos de hidrógeno del organismo se orienten siguiendo la dirección del campo magnético externo. Después, se obra un cambio en la orientación de los momentos magnéticos de estos núcleos mediante el envío de una onda de RF con una frecuencia igual a la de la resonancia de los núcleos de hidrógeno, con lo que éstos absorben energía del haz de RF. A continuación, se interrumpe la onda de RF con lo que los núcleos regresan a la orientación inicial determinada por el campo magnético externo, produciendo una liberación de energía también en forma de RF. Esta energía liberada, que porta gran cantidad de información, es captada por una antena y, más tarde, la aplicación de la transformada de Fourier y el tratamiento informático permiten reconstruir la imagen.

Los recursos técnicos utilizados para la obtención de imágenes de RM se basan en aparatos que cuentan con un imán principal que produce un campo magnético homogéneo e intenso (0,5 - 3 Teslas). La estabilidad del campo magnético en el tiempo se consigue con bobinas superconductoras enfriadas en helio líquido. En el interior del cilindro del imán existen tres sistemas de bobinas que se utilizan para producir gradientes de campo magnético, uno en la dirección del campo principal (eje Z) y dos perpendiculares a este eje (ejes X e Y).

Como la señal de relajación emitida por el volumen elemental de tejido es muy débil hay que intensificarla (secuencia de pulsos). En RM se aplican diferentes pulsos e intervalos de tiempos entre pulsos con lo que se obtienen distintas secuencias. La secuencia se repite varias veces hasta conseguir la información correspondiente a la imagen.

El operador modifica determinados parámetros para influir en la señal resultante de los diferentes tejidos con objeto de visualizar mejor la 
morfología de los órganos: imágenes potenciadas en densidad protónica, T1 y T2.

En las primeras, el objetivo es visualizar las diferencias entre tejidos en su densidad de protones, con independencia de sus enlaces químicos y de las diferencias en T1 y T2; así, el contraste entre píxels puede traducirse en diferencias en la densidad de protones entre vóxels. Las imágenes ponderadas en $\mathrm{T} 1$ tienen como objetivo visualizar las diferencias entre tejidos durante la recuperación de la magnetización de equilibrio longitudinal después de haber sido alterada por un pulso de RF; así el contraste entre píxels puede traducirse en diferencias en $\mathrm{T} 1$ entre los vóxels. Las imágenes ponderadas en T1 son muy anatómicas, facilitando el estudio morfológico de la zona.

Las imágenes ponderadas en T2 tienen como objetivo visualizar las diferencias entre tejidos durante el descenso de la magnetización transversal después de haber sido inducida por un pulso de RF; así el contraste entre pixels puede traducirse en diferencias de $\mathrm{T} 2$ entre vóxels. Las imágenes potenciadas en T2 son más fisiopatológicas y se emplean más para el diagnóstico clínico.

Por otra parte, como el objetivo de la exploración es generar la imagen de un corte del interior del organismo, hay que limitar el proceso de resonancia-relajación a un sólo plano, es decir, tiene que identificar la información proveniente de ese corte y, en concreto de cada uno de los vóxels que lo componen (localización espacial de la señal). El conjunto de señales procedentes de los vóxels que componen el corte explorado es captado mediante una antena. Por eso, en el interior del sistema de bobinas de gradiente se instala una bobina transmisora/emisora de RF. Esta antena 
sirve tanto para transmitir la onda de RF al paciente como para recibir la señal de RF del mismo.

El aparato cuenta además, para colocar al paciente, con una camilla situada en el centro del cilindro.

Finalmente, un sistema computarizado realiza el tratamiento informático que permite obtener las imágenes.

La imagen final de RM es, como en la imagen de TC, una matriz cuadriculada de píxels, cada uno de los cuales representa un pequeño volumen, un vóxel, en un corte imaginario del paciente. A cada pixel se le asigna un valor de la escala de grises proporcional a la amplitud de la radioseñal emitida por el vóxel correspondiente en un periodo de tiempo definido siguiendo una secuencia de excitaciones de RF, elegidas para aumentar las diferencias entre los tejidos respecto a un parámetro particular, como por ejemplo T1 o T2.

Cuando la radioseñal emitida por el corte excitado del paciente es captada por la antena, y sometida a un análisis de Fourier, la frecuencia y la fase de las ondas elementales definen conjuntamente las coordenadas del vóxel a partir del cual se ha originado la onda. A continuación, se puede asignar a la amplitud de la onda elemental un tono de gris proporcional a su magnitud y se visualiza como el pixel correspondiente en la imagen. Por convenio, las amplitudes de señal alta se visualizan hacia el blanco y las bajas hacia el negro en la escala de grises. Como en el caso de la TC, la escala tiene unos 20 tonos y se puede variar la anchura de ventana y el nivel. 
Los tres gradientes utilizados para obtener la resolución espacial de las señales de RM pueden intercambiarse, de forma que los cortes axiales, sagitales y coronales pueden generarse libremente sin mover al paciente.

Los avances técnicos alcanzados en los últimos años con incremento de los campos magnéticos, el desarrollo e incorporación de nuevas antenas de recogidas de datos (antenas multicanal) y la mejora de los procesos informáticos de adquisición de la imagen y su posterior proceso han aumentado las aplicaciones clínicas de esta técnica diagnóstica a todas las regiones anatómicas, siendo la primera modalidad diagnostica en muchas patologías (Riederer, 2004; Runge, 2006).

La RM presenta varias ventajas respecto a otros procedimientos diagnósticos. Ofrece la mejor resolución para tejidos con contraste intrínseco bajo. Además, no utiliza radiación ionizante y, finalmente, como la región del cuerpo explorada se controla electrónicamente, es posible la obtención directa de imágenes multiplanares sin recolocar al paciente. Entre las desventajas o inconvenientes de la RM se incluyen los tiempos de exploración relativamente largos y el riesgo potencial que supone la presencia de metales ferromagnéticos en la vecindad del electroimán, lo cual impide estudiar por RM a enfermos con cuerpos extraños implantados o dispositivos médicos que contengan metales (marcapasos, neuroestimuladores, clips vasculares, etc.). Además, ciertos pacientes sufren claustrofobia cuando se les coloca en el equipo de RM y algunos se niegan a ser estudiados por esta técnica (White y Pharoah, 2001). 


\section{Importancia de la imagen 3D para el diagnostico clínico y el reconocimiento de estructuras anatómicas}

En los últimos años se han llevado a cabo estudios que permiten automatizar el análisis de imágenes médicas y la reconstrucción tridimensional con gran valor para el diagnóstico clínico y para el desarrollo de sistemas quirúrgicos de navegación (Couteau y col., 2000; Burgielski y col., 2002; Dumoulin y col., 2003; Verhey y col., 2006).

Los exámenes tomográficos y de resonancia contienen enorme cantidad de información. Por un lado, la información anatómica "per se" que permite distinguir diversas estructuras, desde tejidos blandos a duros 0 , en el caso del sistema nervioso, reconocer la sustancia gris y blanca y diferenciar los núcleos grises centrales, vasos, ventrículos encefálicos, etc. A esta información se agregan las desviaciones de la normalidad, tanto por aparición de elementos nuevos (por ejemplo, tumores) como por los desplazamientos y cambios en la densidad de los órganos.

Por otro lado, las técnicas de imagen aportan valores numéricos que en la actualidad comienzan a tenerse en cuenta y a comprenderse su significado y aplicación. Por medio de sofisticadas herramientas matemáticas se puede obtener a partir de la RM información del flujo del líquido cefalorraquídeo y tras aplicar paradigmas neurofisiológicos conseguirse información sobre actividad funcional de distintas áreas del cerebro.

Los avances diagnósticos mediante el empleo de técnicas de imágenes revolucionaron el ámbito de la radiología convencional, si bien, fue en la esfera de la neurología donde las contribuciones de las técnicas de imagen (TC, RM, ultrasonidos, etc.) encontraron mayor relevancia, tanto por su 
poder de resolución como por ser mínimamente invasivas. Esta es la razón principal de haberse empleado para el diagnóstico de amplias patologías del sistema nervioso (Ricci, 1999; Riederer, 2004; Ramella y MuciMendoza, 2005; Runge, 2006; Fraile Moreno 2007).

Otra aplicación de las imágenes 3D es en el desarrollo de simuladores clínicos, en especial quirúrgicos. Hasta hace pocos años, las prácticas que recibían los cirujanos se basaban en el empleo de cadáveres, animales vivos o intervenciones quirúrgicas tuteladas; todo ello conllevaba problemas: éticos, escasez de sujetos y posibilidades intervencionistas mínimas en algunas patologías. Con la llegada de la tecnología informática aplicada a la medicina y la generación de modelos 3D surgieron los simuladores quirúrgicos. Sus ventajas son la reducción en costes y en sujetos utilizados, así como el aporte de amplia experiencia para los cirujanos, posibilidad de simular abundantes tipos de patologías y posibles complicaciones, repetir los ensayos quirúrgicos tantas veces como sea necesario, incluso realizar las operaciones virtuales de una forma planificada, en el momento más conveniente para el cirujano (Muller y col., 1997).

Los sistemas de simulación quirúrgica están compuestos básicamente por dos subsistemas: el interface del cirujano, cuya finalidad es suministrar al usuario una visualización de la reconstrucción computarizada de los órganos internos de interés, para lo cual se emplean modelos avanzados de geometría compleja para objetos en visualización 3D y modelos deformables para incorporar propiedades físicas a las estructuras 3D generadas por el ordenador junto con técnicas de visualización avanzadas (Ziegler y col., 1995; Cotin y col., 1996; Montserrat, 1999; Monserrat y col., 2000). 
El segundo subsistema corresponde a los sensores, compuestos por un conjunto de dispositivos "haptic" que pueden imitar a los utensilios empleados por los cirujanos en las situaciones reales de cirugía.

En la creación de estos simuladores se han empleado con éxito los cortes de cadáveres procedentes del "Proyecto Visible Human" (VHP), en sus diversas versiones. El primero se planificó en 1986 por la National Library of Medicine en Bethesda (Maryland, USA) y fue desarrollado por la Universidad de Colorado (Denver, USA). Compila datos a partir de RM, TC e imágenes anatómicas de cadáveres de un varón de 39 años y de una mujer de 59 (Spitzer y col., 1996). El año 2001, se inició en la Universidad de Ajou (Suwon, Corea) el experimento para obtener el "Visible Korean Human" cuyos datos suplementaron a los del VHP (Chung y col., 2000 a y b; Park y col., 2005 a y b, 2006). Poco después se desarrolló el proyecto del "Chinese Visible Human” (Zhang, 2003, 2004) con imágenes anatómicas, de TC y RM de varios cadáveres de varones y mujeres chinos.

Mediante reconstrucción volumétrica, las imágenes de los cortes transversales obtenidos en los diferentes modelos del VHP pueden transformarse en imágenes 3D de estructuras anatómicas, incluidas el cuerpo entero, que constituyen por sí mismas una biblioteca de valor incalculable para la educación médica y para la investigación (Park y col., 2006). A partir de las secciones de los VHP y debido a que los cortes tienen siempre un grosor constante y a que han sido practicados a distancias constantes, es posible crear un medio que puede ayudar al médico en la planificación pre y post-operatoria.

La cirugía asistida por ordenador es un campo de tecnología desarrollado recientemente que intenta crear y dotar de herramientas a los cirujanos para el diagnóstico y la planificación de intervenciones 
quirúrgicas (Adams y col., 1990). Se aplica a un número amplio de especialidades médico-quirúrgicas (Taylor y col., 1996) si bien donde encuentra mayor utilización es en neurocirugía ya que es la especialidad que demanda mayor precisión en el abordaje quirúrgico (Widmann, 2007).

La neurocirugía tradicional implicaba técnicas manuales basadas en la coordinación entre manos y vista del cirujano usando los datos suministrados por técnicas radiográficas proyectivas y signos clínicos deducidos a partir de hallazgos neurológicos que llevaban a largas y tediosas intervenciones con importantes secuelas para los pacientes.

La neurocirugía actual mejora constantemente sus procedimientos teniendo como base los avances tecnológicos en neuroimagen, lo que ha permitido el desarrollo de técnicas neuroquirúrgicas asistidas por ordenador.

En los procedimientos actuales se comienza con una fase de adquisición de datos que defina la lesión patológica y su relación espacial con las estructuras normales que deban ser preservadas. El siguiente paso, tras el diagnóstico, es la planificación quirúrgica que defina el abordaje más seguro durante la intervención y es aquí donde tiene máximo interés la composición 3D de la anatomía del paciente y de la localización de la lesión. Además, imágenes 3D conseguidas durante la cirugía serían útiles para identificar marcas anatómicas con el fin de mantener la orientación espacial (Park y col., 2006).

Los prototipos pioneros en simulaciones quirúrgicas fueron desarrollados sobre Colecistectomía laparoscópica, en la universidad de California (Downes y col., 1997), el Simulador laparoscópico, de la universidad de Misssouri-Columbia (Basdogan y col., 1998); "Virtual Endoscopy" (Robb, 2000); "Hepatic Surgery Simulator" desarrollado por 
Cotin y col. (1996) en Francia; "anastomosis Simulator" desarrollado por Boston Dynamics Inc. o el "Arthroscopic Knee Surgery Simulator" desarrollado por Gibson y col. (1997).

En España, existe una línea de investigación sobre el tema desde hace años y se han desarrollado varios simuladores en la Universidad Politécnica de Valencia para el entrenamiento en cirugía avanzada (Montserrat y col., 2000).

Además de las potenciales aplicaciones de las imágenes 3D generadas a partir de los cortes del "Human Visible" en el campo de la cirugía virtual y de la endoscopia virtual, existen también aplicaciones para la resucitación cardiopulmonar virtual.

Las interpretaciones endoscópicas o broncoscópicas virtuales con color real podrían ser de gran utilidad en el entrenamiento y preparación del personal sanitario.

También puede diseñarse un programa virtual CPR basado en imágenes creadas a partir de imágenes anatómicas segmentadas de tórax. Un maniquí con sensores de presión y utensilios "haptic" podría unirse a las imágenes 3D de la pared torácica, corazón y pulmones, generadas en el ordenador y podrían ir transformándose en tiempo real, a medida que se manipula el maniquí. Cada actuación con la CPR virtual podría ser valorada y puntuada en relación con un patrón previamente diseñado (Park y col. 2006).

\section{La informática médica: programas docentes informatizados.}

El desarrollo de aplicaciones informáticas avanzadas para el estudio de distintos aspectos anatómicos corporales, se está introduciendo cada vez 
con más fuerza en el terreno médico (Gutierrez, 1997), generándose programas muy valiosos para el estudio anatomo-radiológico como el que proponemos para este trabajo de Tesis.

La tecnología informática ofrece enormes beneficios a las actividades docentes y de entrenamiento profesional, porque permite descentralizar y acceder a las principales bases de datos, recopilar y poner al día los conocimientos y evaluar de forma multidisciplinar los problemas que se suscitan a diario en la docencia, investigación y práctica clínica.

El extraordinario desarrollo de las nuevas tecnologías ha provocado enormes cambios en la educación médica. Estos cambios conciernen a varios aspectos de la relación profesor/alumno e implica nuevas tácticas para la enseñanza teórica y práctica y para la preparación de materiales auxiliares (Drake, 1998; Paalman, 2000; Miller y col., 2002; Pereira y col., 2003).

Muchas iniciativas docentes unen nuevas necesidades en el conocimiento anatómico con las cualidades emergentes ofrecidas por los ordenadores (Carmichael y Pawlina, 2000; Trelease y col., 2000; Hallgren y col., 2002) manteniendo resultados prometedores (Reidenberg y Laitman, 2002).

Los desarrollos informáticos 3D, muchos de los cuales tienen como base los cortes anatómicos procedentes de los cadáveres del HVP en sus diversos orígenes (americano, coreano y chino) han revolucionado los paradigmas del aprendizaje anatómico, ya sea por sí mismos o cuando las imágenes 3D se implementan con materiales multimedia y otras fuentes de realidad virtual (Hoffman y Murray, 1999). 
Existen múltiples y variados desarrollos informáticos 3D dirigidos al aprendizaje y mejora de la docencia de la Anatomía, muchos de ellos presentados en CD-Rom's o DVD's, otros localizados en la red y presentados en múltiples "websites".

Los programas multimedia 3D permiten al estudiante y al médico en formación un alto grado de independencia a la hora de programar su formación y la posibilidad de instruirse a distancia a través de Internet accediendo a programas y desarrollos informáticos de universidades repartidas por todo el mundo.

Entre las primeras aplicaciones a los VHP se encuentra la reconstrucción de modelos anatómicos 3D (Kerr y col., 1996). En este tipo de reconstrucciones 3D destacan dos tipos de técnicas cuyos resultados son de gran utilidad en la formación docente de la medicina y en la aplicabilidad al diagnóstico y seguimiento terapéutico de las enfermedades especialmente en las neurológicas.

La primera técnica es la renderización que permite la creación de modelos 3D donde las texturas asignadas a cada objeto pueden ser colores sólidos, lo que resulta útil para identificar y separar estructuras anatómicas.

La segunda técnica es la reconstrucción volumétrica o "visualización" con la que los colores o texturas asignadas a los objetos se obtienen directamente de los valores de cada uno de los vóxels que forman el objeto 3D. Con esta técnica se obtienen reconstrucciones muy realísticas y la posibilidad de ver estructuras situadas en el interior de un corte determinado, a diferencia de la situación en la renderización, donde sólo se consigue la superficie del objeto estudiado. 
Un hecho añadido supone la posibilidad de integrar ambos tipos de técnicas de reconstrucción con lo que se refuerza el objetivo del aprendizaje. Es posible obtener una estructura 3D fotorrealística y, sobre ella, asignar un color ficticio a un objeto, como por ejemplo una arteria, que así destacaría sobre el resto de la estructura 3D (Juanes y col., 2003).

Los desarrollos informáticos 3D deben ser interactivos con el usuario, permitiéndole variar las escenas visuales obtenidas, con rotaciones, cortes, superposición o eliminación de capas, órganos o estructuras, lo que facilita la comprensión de la morfología y relación que mantienen entre sí los diversos objetos que integran la imagen.

A través de imágenes estereoscópicas mezcladas con imágenes de disección junto con narración digital se consiguen programas multimedia interactivos con gran potencial docente (Trelease, 1998). Un ejemplo actualizado de desarrollo informático 3D es el realizado mediante métodos de reconstrucción estereoscópica 3D a partir de imágnes de TC y de RM archivadas en formato DICOM (Imágenes y Comunicaciones Digitales en el ámbito de la medicina, del inglés: Digital Imaging and Communications in Medicine), con el fin de obtener patrones morfológicos y de comportamiento de estructuras vasculares cerebrales que puedan aplicarse al diagnóstico y evaluación terapéutica de aneurismas y otras alteraciones vasculares endocraneales (Zurada y col., 2008).

Otro programa de desarrollo informático 3D con gran impacto entre los anatomistas y con gran potencial didáctico para la enseñanza y aplicabilidad de la neuroanatomía es el denominado Voxel-Man, el cual es fruto de un proyecto de investigación cuyo objetivo era representar la morfología y la función del cuerpo humano mediante técnicas basadas en la utilización de ordenadores (Schubert y col., 1997; Pflesser y col., 2001). El 
Voxel-Man/brain es un modelo obtenido a partir de cortes de RM tomados con una resolución espacial de $1 \mathrm{~mm}$; incluye además imágenes de la colección VH. En el modelo Voxel-Man/skull se utilizaron imágenes de TC obtenidas con una resolución espacial de $1 \mathrm{~mm}$. El proyecto Voxel-Man, desarrollado por el "Institute of Mathematics and Computer Science in Medicine" (IMDM) de Hamburg, 1998, está basado sobre un modelo de cuerpo virtual que permite realizar múltiples y diferentes tipos de exploración lo que le convierte en una excelente herramienta para la enseñanza de la anatomía humana y de la anatomía radiológica.

Un nuevo intento para mejorar los desarrollos informáticos 3D y su aplicación a la docencia de la medicina consistente en tratar de unificar los sistemas de anatomía virtual 3D (basados en sitios Web, incluyendo VH databases e interfaces de navegación), con utensilio "haptic" que permiten añadir el tacto a las estructuras geométricas generadas (Temkin y col., 2002).

Los programas docentes informatizados no se ha estancado en los últimos años; por el contrario, el desarrollo tecnológico aplicado a los grandes aparatos para el diagnóstico de la imagen (por ejemplo, el TC helicoidal multicorte) junto al gran desarrollo de las técnicas infográficas están consiguiendo nuevos y depurados desarrollos informáticos al servicio de la medicina que irán modificando los sistemas de enseñanza en medicina, como ya se está haciendo en los países con la tecnología más avanzada. 


\section{PLANTEAMIENTO DEL TRABAJO}


Los conocimientos anatómicos tienen especial relevancia no sólo para el aprendizaje de la vía óptica sino también para su aplicación en el diagnóstico y tratamiento de las múltiples enfermedades neurooftalmológicas. La anatomía de las paredes y del contenido orbitario es esencial para el diagnóstico y tratamiento de enfermedades palpebrales, conjuntivales, de la vía lagrimal, del globo ocular (en sus diversas capas y estructuras), del nervio óptico, de la musculatura extrínseca ocular así como del contenido vascular y nervioso orbitario (Hubel, 2000; Pérez Moreiras y col., 2000; Wright y Spiegel, 2001; Rapuano y col., 2001; Kaufman y Alm, 2007).

El aprendizaje de la anatomo-fisiología de la vía óptica ha sufrido cambios importantes, en especial en los dos últimos siglos, en relación con los formatos y tecnología disponibles para la transmisión de los conocimientos.

Hasta lo que conocemos, durante los primeros siglos de nuestra era y durante toda la edad media, el estudio de la vía óptica fue totalmente empírico y basado en textos de Galeno o de médicos árabes que tradujeron a Galeno. En todos ellos, apenas existen ilustraciones, siendo fundamentalmente descriptivos. Por eso, el estudio de los órganos, aparatos y sistemas se hacía basado en lecturas de las obras clásicas. 
Con la llegada del Renacimiento proliferan las obras anatómicas con abundantes imágenes. A partir de Vesalio y con la aparición de la imprenta se produce el gran salto en la imagen anatómica, con la aparición de láminas e ilustraciones, en blanco y negro, donde se hace fiel traducción de los detalles anatómicos observados en las disecciones de cadáveres humanos, entre ellos los globos oculares, el contenido orbitario y los nervios ópticos.

Durante los siglos XVII y XVIII, prosigue la publicación de libros anatómicos en las principales universidades del viejo mundo con abundantes y detalladas ilustraciones en blanco y negro y si bien los capítulos dedicados a la vía óptica no son prolíficos, al menos tienen alta calidad (Rifkin y col., 2006). Además, en los siglos XVIII y XIX, surgen las representaciones anatómicas tridimensionales, modeladas en cera, en las que intervenían anatomistas y modelistas (“ceraioli”), que adquieren gran prestigio, en especial los talleres Florentinos (Clemente Susini, 1754-1814) y las colecciones existentes en Austria (Cattaneo, 2007).

Con los avances tecnológicos y la revolución industrial (empleo de tintes, grabados litográficos y perfeccionamiento en el trabajo de las imprentas), emergen en el siglo XIX, no sólo ilustraciones sino también Atlas de Anatomía a todo color que mejoran la presentación, comprensión, reconocimiento y, por tanto, aprendizaje de las estructuras anatómicas, incluidas las relacionadas con la vía óptica.

En pleno siglo $\mathrm{XX}$, la fotografía en color y la aparición de las diapositivas, permite un mayor realismo anatómico ya que puede plasmarse en papel fotográfico o en película positiva, las disecciones efectuadas en los cadáveres humanos, las cuales pueden retocarse mediante inyección de 
colorantes en órganos huecos o simplemente pintando externamente, con tinta de diferentes colores, las estructuras vasculares, nerviosas o tubulares.

Otro adelanto consistió en el desarrollo de reconstrucciones planimétricas, como las diseñadas por el Profesor Escolar (Smith, 2007), vigentes en nuestros días y que constituyen una herramienta didáctica altamente cualificada, con alto valor descriptivo y topográfico, en especial en lo referente a los sentidos de la vista y del oído.

Entre enseñanza y arte, se encuentra en la actualidad, las técnicas de plastinación de órganos y cuerpos humanos, iniciada en los años 70 por el anatomista alemán Gunther von Hagens y seguidas por múltiples escuelas en todo el mundo. Con la plastinación se consigue la conservación perdurable de las disecciones anatómicas y un gran contraste entre las formas transparentes y las opacas. Las disecciones plastinadas de la cabeza muestran con alto detalle el contenido orbitario y gran parte de la vía óptica (Sora y col., 2002; Gotwald y col., 2003).

A finales del siglo pasado, la Anatomía participó del desarrollo tecnológico y cibernético, con lo que surgieron ilustraciones, libros y atlas digitales, con gran interacción por parte de los usuarios.

Muchos de los programas digitales aplicados a la Anatomía se basan en el VHP, permitiendo a los alumnos y usuarios rotar hasta $360^{\circ}$ las imágenes, adicionar o sustraer planos y estructuras anatómicas, o encontrar hipertextos y material multimedia. Son ejemplos de esta versión digital de atlas anatómico, el New Atlas of Human Anatomy (McCracken, 2000) y el programa Primal Pictures ${ }^{\circledR}$, perteneciente a la base de datos Ovid (Primal pictures limited, 2007). 
En los últimos 10 años las aplicaciones multimedia, unidas a los atlas anatómicos digitales, se han multiplicado incesantemente, en especial en el campo de la neuroanatomía (Prats-Galino, 2000), existiendo dos tipos de programas comerciales disponibles: los programas "lineares" con abundantes imágenes a las que se accede a través de índices temáticos, conteniendo imágenes anatómicas y radiológicas estáticas, animaciones y vídeos en formato de atlas electrónico (Abrahams, 1998; Viaño y col., 1999) y los programas de "navegación libre" con acceso flexible a la navegación, como simulación de disecciones, cortes anatómicos o uso de modelos sintéticos 3D para vistas preprogramadas (Bulling y col., 1999).

Las técnicas de diagnóstico por la imagen, en especial la TC y la RM, han supuesto un doble revulsivo que permite profundizar no sólo en el aprendizaje de la anatomía sino también en el diagnóstico de múltiples y variadas patologías oculares, paraoculares y aquellas relacionadas con la vía óptica (Ramella y Muci-Mendoza, 2005), con sus ventajas e inconvenientes en lo referente a su aplicación al estudio anatómico, clínico y terapéutico (Dutton, 1999; Koenigsberg y col., 2003; Ramella y MuciMendoza, 2005). Uno de los inconvenientes que presentaban las imágenes TC y RM era que les faltaba la tercera dimensión; por eso, los estudios se encaminaron a obtener imágenes en 3D, lo cual se consiguió con la llegada de la digitalización de estas imágenes, pues al ser tomográficas y estar digitalizadas, el ordenador puede apilarlas y así reconstruir partes e incluso el cuerpo humano en 3D.

La imbricación entre objetivos docentes y diagnósticos se hizo posible a partir de la última década, al desarrollarse sistemas que permitían automatizar el análisis de imágenes médicas, con el objetivo de servir de apoyo en el diagnóstico clínico, mediante la reconstrucción y visualización en tres dimensiones (3D) de estructuras anatómicas; estos sistemas aportan 
una valiosa información que hace muy comprensible determinados aparatos y sistemas, entre ellos la vía óptica y sus anexos musculares. Por otro lado, es fundamental para el entrenamiento de postgrado de cirujanos oftalmólogos conocer los rudimentos de la anatomía radiológica, la interpretación de las neuroimágenes y la aplicación de los hallazgos aportados por las imágenes en el contexto particular de cada enfermo.

Existen en la actualidad desarrollos informáticos realizados a partir de imágenes de RM (Tiede y col., 1993; Juanes y col., 1996; Perry y Kuehn, 2007; Rubod y col., 2006; Shattuck y col., 2008; Howden y col 2008; Rhee y col., 2008) que poseen la ventaja sobre los creados a partir de los VHP de que las imágenes se obtienen en sujetos vivos, de diferentes edades, razas y condiciones socio-culturales. Esto permite a los especialistas (oftalmólogos, cirujanos, neurólogos y radiólogos), estudiar al propio paciente proporcionándoles la disposición exacta de sus órganos, que puede ser diferente de unos individuos a otros.

La alta resolución de la resonancia magnética mediante el uso de nuevas bobinas, aumentó la sensibilidad en el reconocimiento de estructuras anatómicas, facilitando la identificación diagnóstica de posibles anomalías congénitas y tumores intraorbitarios e intracraneales que afecten o repercutan sobre la vía óptica (Atlas y Galetta, 1991; De Potter y col., 1993; Ramella y Mucci-Mendoza, 2005). Su capacidad multiplanar y de diferenciación de las partes blandas, hacen de ella una excelente técnica de diagnóstico por imagen no invasiva, tanto para el estudio normal como patológico de la vía óptica.

El aumento en la generación de imágenes 3D del cuerpo humano y la implementación de aplicaciones informáticas avanzadas para la visualización de modelos-3D de estructuras anatómicas han desembocado 
en el uso de este tipo de imágenes 3D en diferentes ámbitos médicos (Fielding y col., 2000; Hoyte y col., 2001) erigiéndose en potentes herramientas para el estudio anatomo-radiológico y para las intervenciones asistidas por ordenador, que comienzan a ser una realidad en las actuaciones neuroquirúrgicas.

Sin embargo, los modelos 3D relacionados con la vía óptica, se han focalizado sobre todo en su porción intraorbitaria y en los anejos ubicados en esa cavidad (Iwamoto y col., 1997; Gilles y Dodgson, 2002; Inostroza, 2005; Masuko y Hoshino, 2006; Mann y col., 2006) o bien en la reconstrucción 3D de mapas retinotópicos (Warnking y col., 2002; Dumoulin y col., 2003; Olman y col., 2003; Vanni y col., 2005). Por eso, nuestro propósito es generar un desarrollo informático 3D a partir de imágenes de RM, que incluya todo el trayecto de la vía óptica así como los complejos sistemas neuromusculares asociados al globo ocular, que pueda ser de utilidad tanto en el aprendizaje complejo de las relaciones espaciales de la vía óptica intraorbitaria e intracraneal, así como servir de complemento a la comprensión e interpretación del diagnóstico clínico y a la planificación de tratamientos quirúrgicos neuro-oftalmológicos.

Los objetivos que nos hemos marcado a la hora de planificar el presente trabajo de Tesis Doctoral han sido:

1.- Conocer las posibilidades de la Resonancia Magnética de alto campo en el estudio morfológico de la órbita y su contenido

2.- Proporcionar conocimientos sobre la compleja Vía Óptica y sistema oculomotor, mediante su visualización en diferentes posiciones espaciales y en imágenes 3D. 
3.- Desarrollar capacidades y destrezas a través de la utilización de los sistemas informatizados, de simulación gráfica y visualización espacial, que permitan desde un punto de vista docente, facilitar el proceso de enseñanza-aprendizaje de estas estructuras anatómicas.

4.- Generar una herramienta informática, que sea útil y complementaria para la práctica de planificaciones y de abordajes quirúrgicos de posibles patologías de la vía óptica.

5.- Aumentar la motivación de profesionales oftalmólogos, residentes hospitalarios, estudiantes de medicina, etc., proporcionándoles un recurso adicional de aprendizaje y destreza en el conocimiento de la vía óptica y estructuras del sistema oculomotor.

Para conseguir los objetivos marcados se empleará la resonancia magnética de alta resolución, la cual permite obtener imágenes para identificar las principales estructuras óseas, musculares, nerviosas y vasculares orbitarias e intracraneales, obteniendo un excelente mapa anatómico de los músculos extraoculares, de los pares craneales que los inervan, así como del cerebro y estructuras endocraneales relacionadas con la vía óptica, para su identificación, delimitación y posterior reconstrucción $3 \mathrm{D}$.

Pretendemos que la aplicación informática que se propone suponga un buen método de visualización 3D, teniendo como referencia las secciones de RM en los tres planos del espacio, lo que facilitará su valoración anatómica, haciendo uso de las capacidades gráficas avanzadas que hoy en día ofrecen los ordenadores.

Para el desarrollo de nuestra aplicación informática, utilizaremos tecnología informática, de última generación, empleando para su 
elaboración, software de creación propia, así como estándares del mercado, con el fin de que el desarrollo informático se presente en un soporte compatible con la mayoría de los equipos informáticos y con las diferentes versiones del sistema operativo Windows, que disponen la mayor parte de los alumnos y de los centros universitarios y hospitalarios españoles.

En una primera fase de nuestro desarrollo, se recogerán las imágenes radiológicas procedentes de Resonancia Magnética en formato DICOM, para la posterior identificación de las diferentes estructuras anatómicas que configuran la vía óptica y los sistemas neuromusculares paraoculares.

Las imágenes seccionales de la cabeza, en los tres planos del espacio y todos los modelos anatómicos 3D se visualizarán en un software, específicamente desarrollado por nosotros, que será programado en Visual C y que incluirá controles directX para la renderización de imágenes y modelos de malla triangular. Mediante la generación de un visor, podremos representar las escenas gráficas en cualquier orientación y almacenarlas en formato bitmap.

Obtendremos así un primer prototipo, Beta 2, que incorporará ya todos los contenidos y las diferentes funcionalidades que conformaran el máster definitivo.

El software a desarrollar se orientará hacia un modelo centrado en el usuario, basándose en el autoaprendizaje y la autoformación en la vía óptica.

Con el desarrollo informático que proponemos, pretendemos que además de los objetivos propuestos anteriormente se alcancen otras finalidades y propósitos de interés, como: 
$\checkmark$ Disminuir los costos en la formación de los estudiantes, al manejar un material reproductible sin gasto adicional.

$\checkmark$ Ampliar la cobertura de la formación médica académica.

$\checkmark$ Desarrollar habilidades en el uso de la informática y las tecnologías docentes innovadoras.

A la hora de diseñar nuestra aplicación docente, tendremos en cuenta que nuestro procedimiento informático debe cumplir una serie de requisitos, entre los que destacamos: su utilidad práctica para el usuario, que tenga permanencia en el tiempo, y que sea innovador (con arquitectura abierta e innovadora). 


\section{MATERIAL Y MÉTODOS}




\section{Adquisición y Procesamiento de Imágenes}

Se ha obtenido una Resonancia Magnética (RM) utilizando un scanner de 1.5 Teslas (Philips Medical Systems) de una mujer voluntaria de 34 años de edad y sin antecedentes de patología neurológica. El protocolo de adquisición ha consistido en una secuencia 3D de la cabeza en el plano axial, con los siguientes parámetros: repetition time $=412$; echo time $=6.4 ;$ inversion time $=300 ; 1.6-\mathrm{mm}$ thickness; slice spacing $=$ $0.8 \mathrm{~mm}$; matriz $=256 \times 256 ;$ flip angle $=90$.

Un volumen T1 fue reconstruido a partir de los ficheros raw data DICOM y salvado en formato ANALYZE 7.5 mediante el software MRIcro (Nottingham, UK). La RM se reorientó de acuerdo con el plano bicomisural, con la finalidad de estandarizarlo, y fue resampleado para obtener un volumen final con voxels cúbicos de $0.8 \mathrm{~mm}$ y dimensiones de 276×276×200. A partir de este volumen se exportaron imágenes en formato PNG en los tres planos ortogonales -axial, coronal y sagital- para su representación en un visor 3D (ver la sección visualización y renderización).

Para la reconstrucción del esfenoides se realizó una tomografía computerizada (TC) de un hueso aislado, obteniéndose un volumen final de $512 \times 512 \times 117$ vóxels, y tamaño de $0.23 \times 0.23 \times 0.5 \mathrm{~mm}$. 


\section{Obtención de modelos tridimensionales (3D)}

La generación de los modelos 3D ha requerido tres tipos de procedimiento, de acuerdo con el tipo de estructura anatómica a reconstruir. Estos han incluido: (1) reconstrucción de modelos de superficie a partir de RM; (2) reconstrucción del hueso esfenoides a partir de TC; y (3) reconstrucción del trayecto de los nervios del sistema oculomotor a partir de RM.

\section{Modelos de superficie en $R M$}

Los diferentes componentes de la musculatura extrínseca ocular y del sistema visual desde el globo ocular hasta el córtex visual se han identificado en la RM y labelado manualmente con diferentes códigos de color (Fig. 13), mediante un editor 3D (Amira software, from Mercury/TGS-Europe, Inc., Marignac, France). Se han identificado para su reconstrucción, bilateralmente, las siguientes estructuras: músculos rectos superior, inferior, medial y lateral; músculos oblicuos superior e inferior; músculo elevador del párpado superior; globo ocular; nervio óptico, quiasma óptico, tracto óptico, núcleo geniculado lateral, radiaciones ópticas y córtex visual primario; y, tronco del encéfalo y cerebelo.

A partir de cada una de las regiones de interés (ROIs) resultantes se ha obtenido un modelo de superficie, compuesto por una malla triangular, mediante un procedimiento de marching cubes (Fig. 14). A los modelos triangulares han sido aplicados algoritmos de decimación para simplificarlos y suavizarlos. Finalmente se han exportado a formato directX (3D Exploration software, from Right Hemisphere, Inc, Auckland, New Zealand). 


\section{Modelo del hueso esfenoides}

Para la generación de un modelo 3D del hueso esfenoides corregistrado con la RM, se ha precisado de dos etapas sucesivas. En una primera, se ha delimitado su ROI tomando como referencia la imagen de TC (Fig. 15). Mediante el mismo tipo de procedimiento descrito previamente, se ha obtenido un modelo prototipo de esfenoides, en el espacio nativo (Fig. 15).

En una segunda fase se ha calculado una transformación geométrica para obtener una alineación aproximada de este modelo prototipo a la RM. Este procedimiento ha sido guiado visualmente, y ha precisado la visualización simultánea del modelo de superficie y de los tres planos ortogonales de la RM de referencia (Fig. 16). La matriz de transformación resultante ha sido, entonces, aplicada a la ROI del esfenoides (fig. 16). La ROI transformada ha sido re-editada para conseguir una máxima adaptación a la RM, empleando como referencias anatómicas: paredes orbitarias, fisura orbitaria superior, foramen óptico, cuerpo y seno esfenoidal, silla turca, clivus, apófisis pterigoides y los contornos de los lóbulos frontal y temporal, todas ellas estructuras que son fácilmente identificables en la RM (Fig. 16).

A partir de la ROI transformada y re-editada se ha obtenido un fichero en formato directX del modelo de superficie definitivo del hueso esfenoides.

\section{Modelos de los nervios motores oculares periféricos}

La reconstrucción del trayecto periférico de los nervios oculomotor (III), troclear (IV) y abducens (VI) se ha obtenido trazando polilíneas sobre 
la imagen de RM (Fig. 17). Para cada nervio se ha colocado una serie de landmarks a lo largo de su trayecto, desde su origen en la superficie del tronco del encéfalo hasta su llegada a la órbita para su inserción muscular. La identificación sin ambigüedad de estos nervios sólo es posible en los primeros milímetros de su origen. El resto del trayecto se ha basado en el conocimiento anatómico, utilizando referencias reconocibles en la RM, tales como el contorno del tronco del encéfalo, el seno cavernoso, la fisura orbitaria superior y la musculatura extrínseca ocular. Los diferentes landmarks han sido unidos mediante polilíneas (Fig. 17), que han sido utilizadas como base para generar una secuencia de cilindros de pequeño diámetro, representando el trayecto nervioso. Al igual que en los casos anteriores, cada nervio se ha representado mediante un modelo independiente en formato directX.

\section{Visualización y renderización}

Imágenes seccionales procedentes de la RM seleccionadas en los tres planos espaciales y todos los modelos 3D de superficie obtenidos en la fase anterior han sido visualizados en ViX. Este es un software específicamente desarrollado por nosotros, en colaboración con la empresa Abadía Group, Madrid, programado en Visual $\mathrm{C}^{++}$, y que incluye controles de directX para la renderización de imágenes y modelos de malla triangular. El visor permite representar las escenas gráficas en cualquier orientación y almacenarlas en formato bitmap (bmp), se han obtenido todas las imágenes de las vías visuales incluidas en este trabajo.

\section{Material documental iconográfico:}




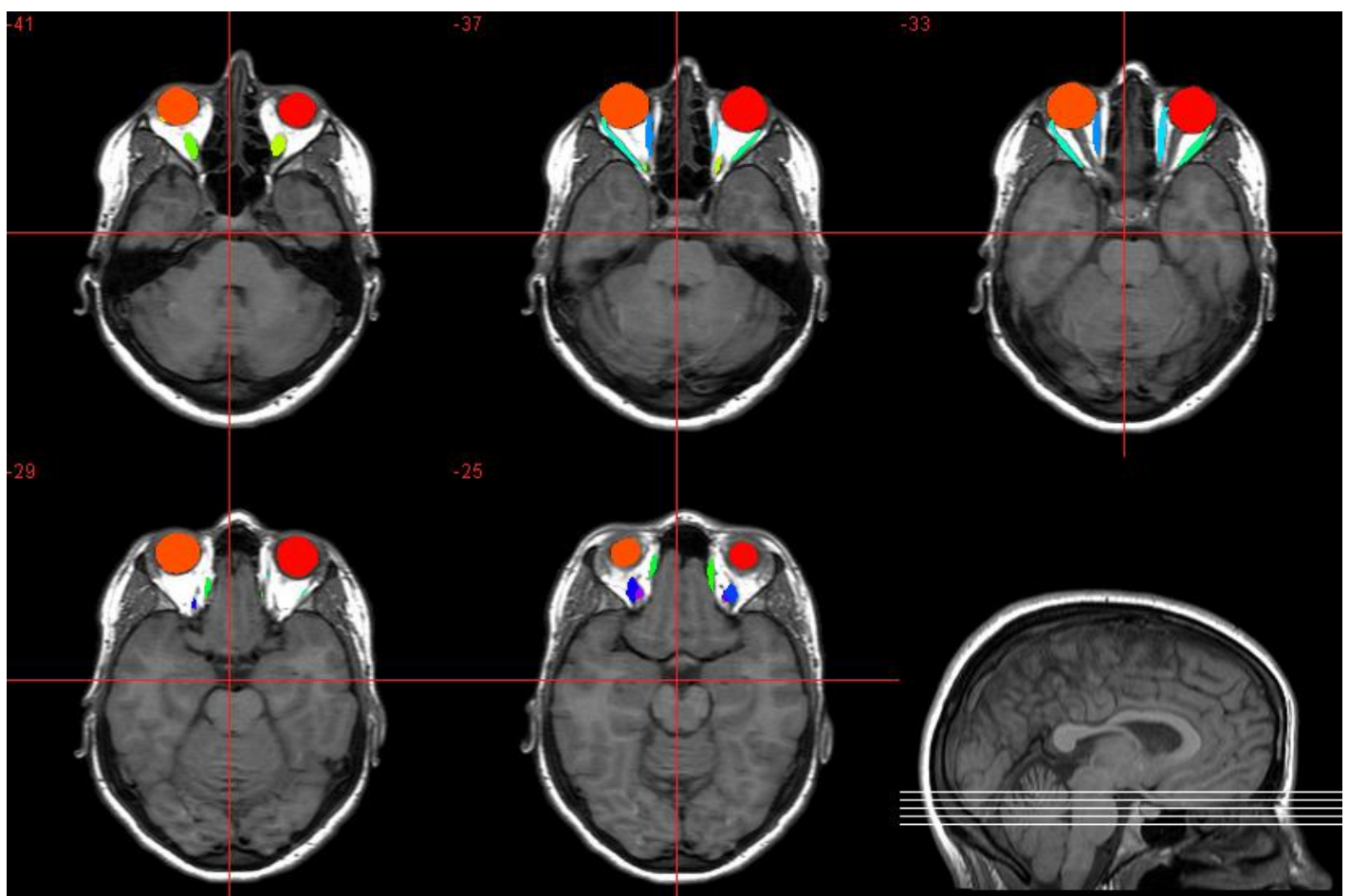

Figura 13.- Ejemplo de ROIs dibujados con diferentes códigos de color sobre la RM, correspondientes al globo ocular y a los músculos extrínsecos oculares, en 5 secciones axiales representativas. Su nivel exacto se indica en la imagen sagital de referencia.

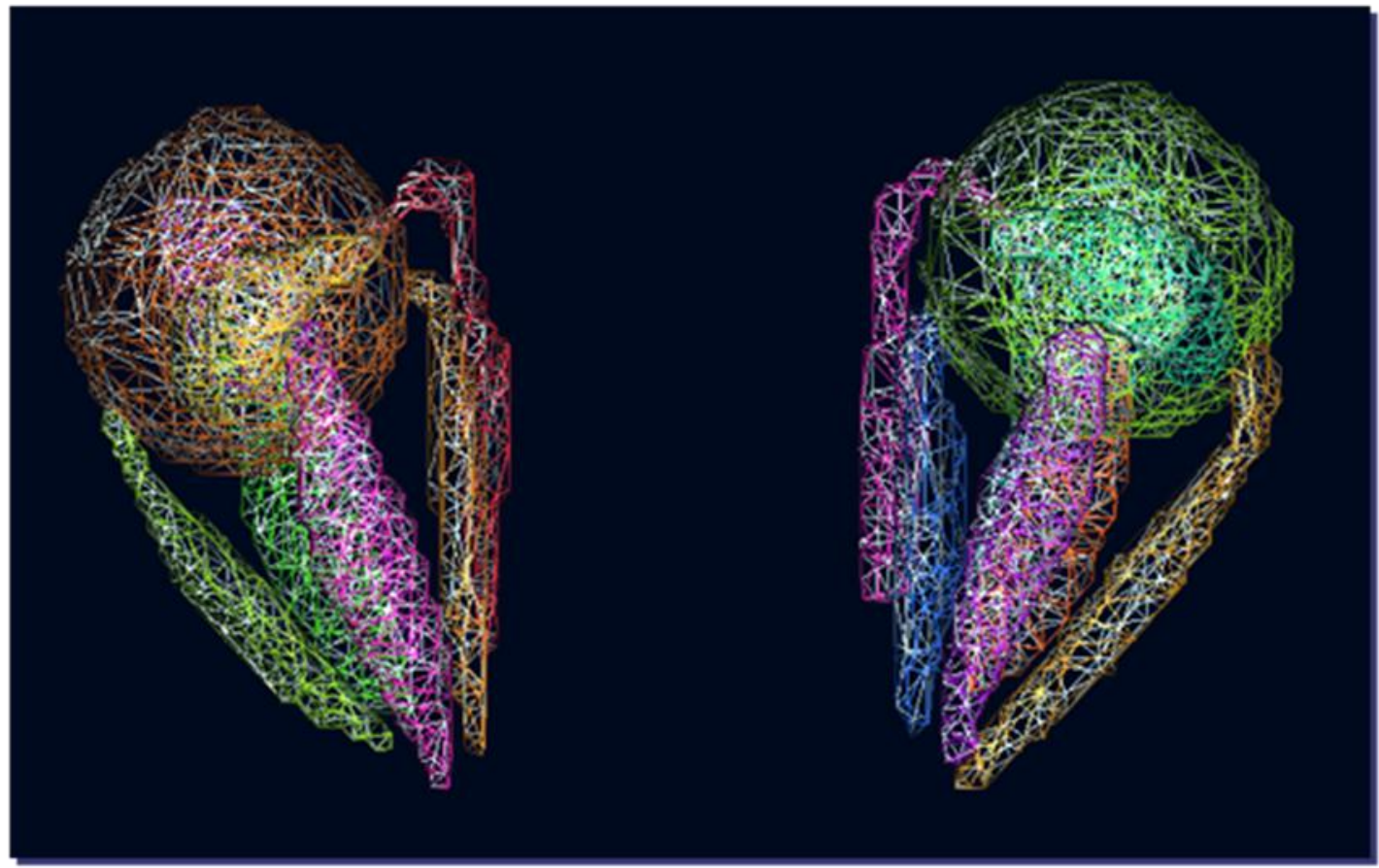

Figura 14.-Representación de la malla triangular de los modelos de superficie del globo ocular y de la musculatura extrínseca ocular obtenidos a partir de sus ROIs. 


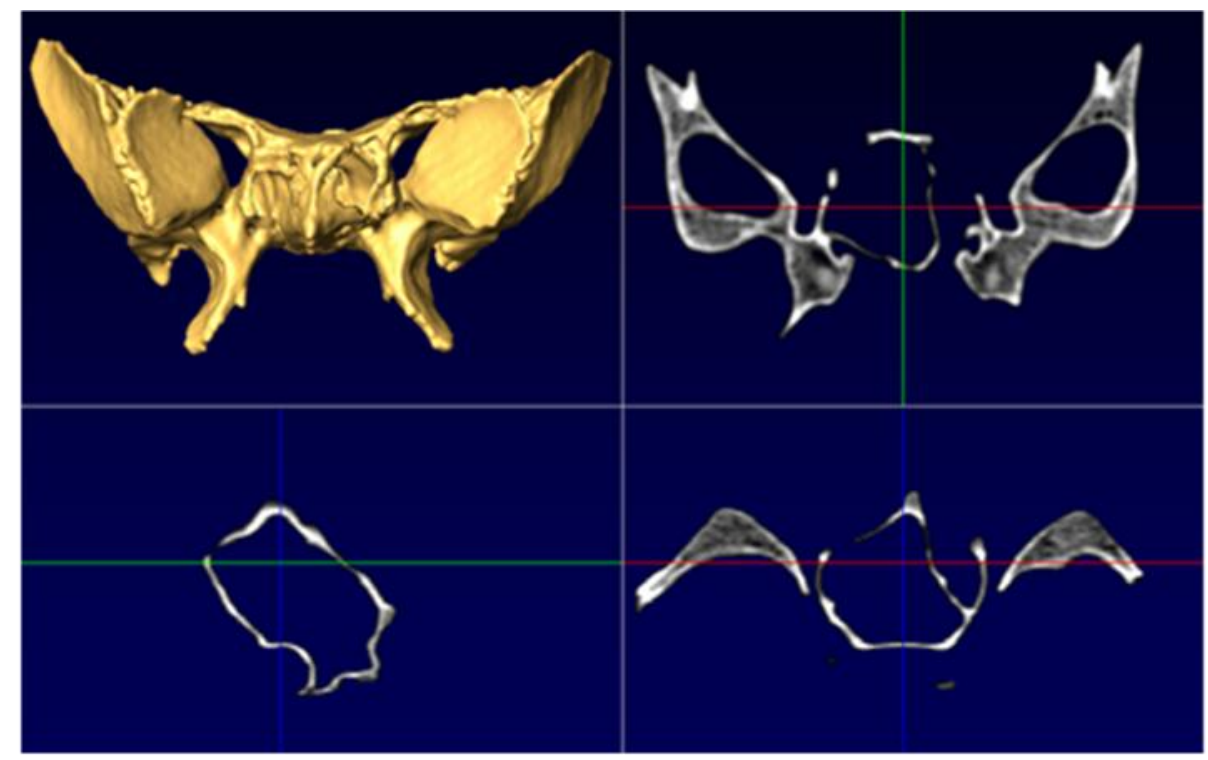

Figura 15.-Visión coronal (arriba izquierda), sagital (abajo derecha) y axial (abajo derecha) de la imagen TC de alta resolución del hueso esfenoides, en su espacio nativo. En la parte superior izquierda se muestra un modelo de superficie de este hueso en visión anterior, obtenido a partir de su ROI.

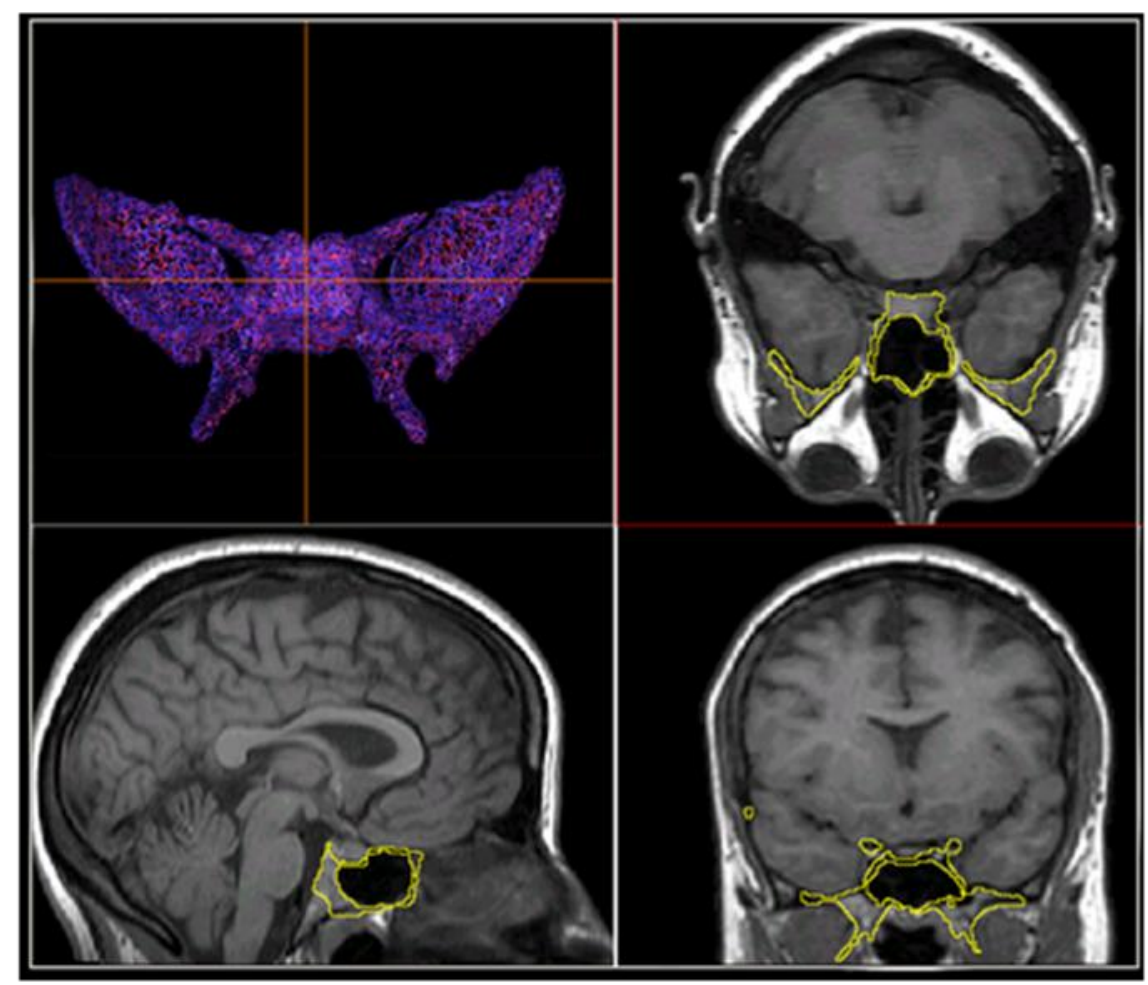

Figura 16.-ROI del hueso esfenoides, en los tres planos ortogonales del espacio, después de aplicar una transformación geométrica para alinearlo con la RM y de su reedición para adaptarlo a las estructuras anatómicas de ésta empleadas como referencia. En la parte superior izquierda se representa el modelo de malla triangular del hueso esfenoides transformado, en visión posterior. 

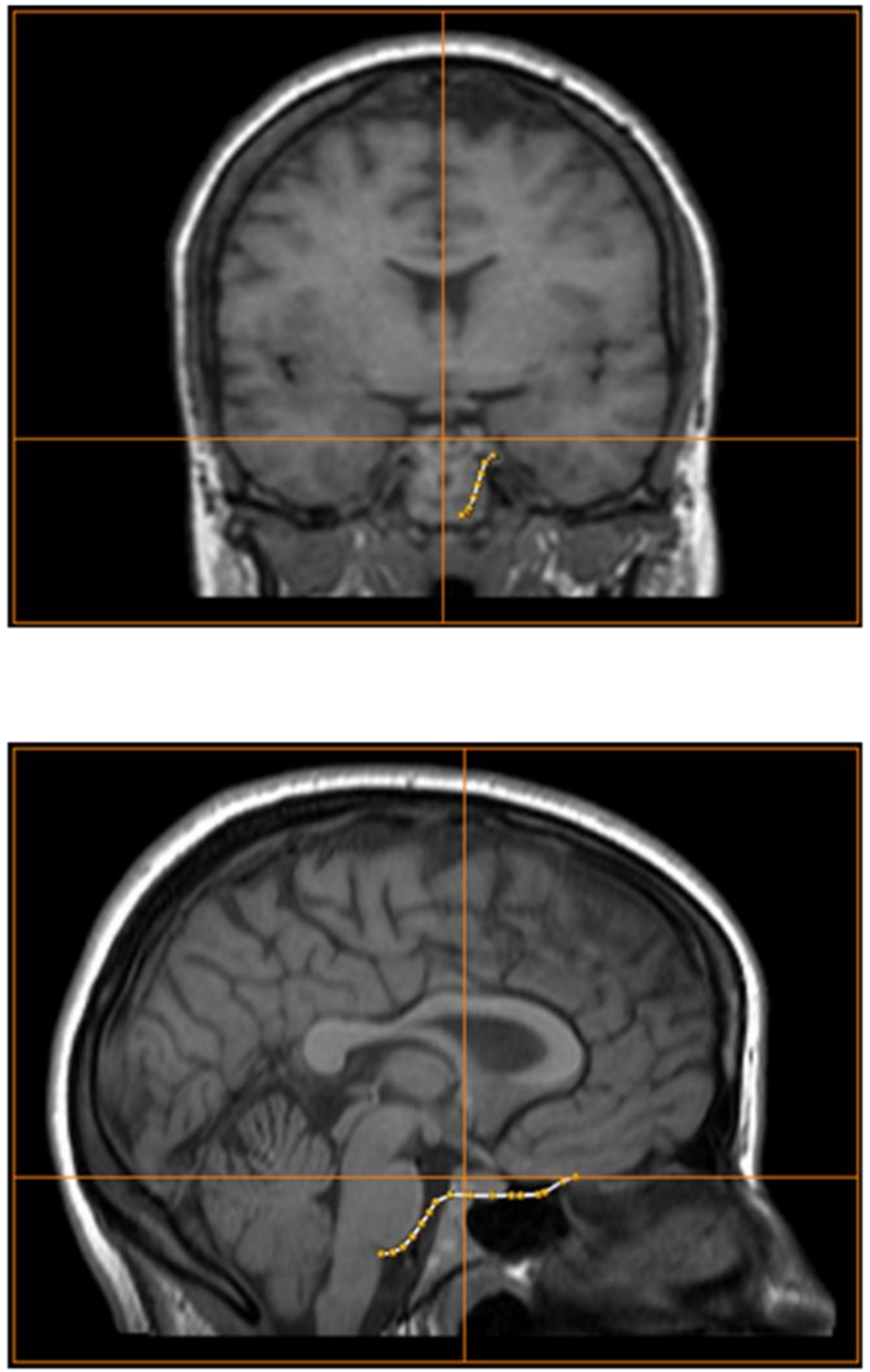

Figura 17.- Ejemplo del trazado del trayecto periférico del nervio abducens mediante la colocación de una serie de landmarks situados en el espacio (esferas naranjas) unidos por segmentos cortos (cilindros blancos), y proyectados en los planos coronal (imagen superior) y sagital (imagen inferior). 


\section{RESULTADOS}




\section{Vía óptica:}

El estudio con Resonancia Magnética de alta resolución permitió identificar las estructuras que integran la vía óptica así como el sistema oculomotor (nervios y músculos extrínsecos), obteniendo así un excelente atlas iconográfico para su identificación, delimitación y posterior reconstrucción tridimensional. Su alta resolución de contraste para el estudio de los tejidos blandos, ofreció un mapa anatómico claro y preciso del contenido orbitario e intracraneal, sin necesidad de administrar medios de contraste.

Mediante esta técnica de diagnóstico por imagen hemos podido valorar con precisión los elementos anatómicos que integran la vía óptica y los sistemas neuromusculares extraoculares, mediante la obtención de cortes tomodensitométricos seriados en los tres planos del espacio: axial, sagital y coronal (Figs. 18, 19 y 20).

La intensidad de la señal dependió de la naturaleza de la secuencia de impulsos y del valor de los parámetros tisulares T1 y T2. Si bien hemos manejado secciones con diferentes ponderaciones para la identificación de estructuras anatómicas (Fig. 21), para la aplicación informática que presentamos hemos utilizado imágenes de RM potenciadas T1 (Fig. 22), 
las cuales presentan una buena relajación señal-ruido, proporcionando un buen análisis anatómico de las distintas estructuras, respecto a las otras potencialidades (Fig. 21).

Es habitual comenzar, como en nuestro caso, por una exploración mediante imágenes de localización rápida de la estructura anatómica a estudiar. Posteriormente practicamos las exploraciones en los 3 planos de corte que más tarde se posicionaron conjuntamente. Esto nos facilitó, mediante barridos de imagen en los diferentes planos, valorar en toda su extensión los elementos anatómicos constituyentes de la vía óptica (Fig. 23).

Si bien, la RM, dada su excelente diferenciación tisular, ayuda a identificar entre partes óseas y blandas, el vacio de señal de los protones inmóviles no permite la detección directa de los huesos cráneo-faciales por lo que éstos aparecen en negro. Sin embargo, cuando la cortical ósea está adyacente a un tejido generador de señal, como el cerebro sobre el techo de la órbita o el músculo temporal en la pared lateral de la órbita, los bordes óseos pueden ser delineados claramente (Fig. 22). Por eso, para mejorar los resultados y apoyarnos en la visualización y relaciones nerviosas y musculares en el fondo de la órbita, se interpoló la imagen CT del esfenoides a las imágenes de RM (Fig. 24).

La interpolación TC del hueso esfenoides permitió una excelente visión del conducto óptico perforado en el ala menor, por dentro de la apófisis clinoides anterior (Fig. 25). Cada conducto óptico se abre en el surco o canal prequiasmático, cuyo labio posterior corresponde al tubérculo selar que delimita ventralmente la silla turca o fosa pituitaria. A ambos lados de la silla turca, la RM deja ver la porción intracavernosa de 
la arteria carótida interna (Fig. 26) y el ligamento petroclinoideo de Gruber, pliegue dorsal que se extiende desde la apófisis clinoides posterior hasta el vértice del peñasco, formando un pasadizo para el nervio motor ocular externo.

A continuación, analizaremos las estructuras anatómicas comenzando por la descripción de la vía óptica, para seguir con los músculos extraoculares que mueven el ojo y terminaremos con la descripción de los nervios oculomotores que los inervan.

El globo ocular, órgano fundamental de la visión, lo observamos en el interior de la cavidad orbitaria, como una esfera con dos segmentos acoplados, uno posterior, el más extenso, y otro anterior, de menor radio de curvatura. Su visualización es fácilmente identificable por su baja intensidad de señal en las secciones de resonancia magnética (Fig. 27), que contrasta con la grasa periorbitaria, lo que facilitó su reconstrucción tridimensional con las técnicas informáticas (Fig. 28). Las imágenes de RM son capaces de poner de manifiesto la cornea y la esclerótica, el cristalino y su cápsula, el humor acuoso de las cámaras anterior y posterior del ojo, el humor vítreo y la úvea (Fig. 27).

Del polo posterior del globo ocular, parte el nervio óptico, con un trayecto sinuoso (Fig. 28), lo que evita los estiramientos con los movimientos oculares.

Mediante Resonancia Magnética de alto campo, el nervio óptico, II par craneal, fue fácilmente visible en las tres incidencias (axial, coronal y sagital), según se aprecia en la figura 29. Ambos nervios ópticos penetran en la cavidad craneal, rodeados por una funda de duramadre, a través del 
conducto óptico y alcanzan el quiasma óptico que siempre es muy visible (Fig. 25). Estas estructuras anatómicas son fácilmente distinguibles en las reconstrucciones 3D (Fig. 30).

El nervio óptico está rodeado por el espacio subaracnoideo, fácilmente identificable en secuencias T2 (Fig. 21), por la hiperintensidad de señal del líquido cefalorraquídeo. Esto explica que un aumento de la presión intracraneal, se transmite a este nervio produciendo un edema de papila, de gran importancia en el diagnóstico de procesos expansivos intracraneales.

El trayecto del nervio óptico es oblicuo hacia atrás y hacia la línea media, pudiéndose diferenciar cuatro porciones anatómicas identificables en las secciones de resonancia magnética: una intraocular, de tan solo 1 mm (Figs. 23, 24, 27 y 29); otra orbitaria, situada en el interior de la cavidad orbitaria, de aproximadamente $35 \mathrm{~mm}$ de longitud, fácilmente visible en las secciones de resonancia magnética y su reconstrucción tridimensional (Figs. 29 y 30); discurre, hacia atrás, en el centro del cono muscular hacia el vértice de la órbita donde aborda el conducto óptico; la tercera porción o intracanalicular, corresponde al tramo situado en el interior del conducto óptico (Fig. 30), el cual forma un ángulo de unos 35 은 con el plano sagital; y una porción intracraneal, de unos $10 \mathrm{~mm}$ de longitud, que termina en el quiasma óptico. (Figs. 30 y 31). Ésta última porción se dispone bajo el segmento A1 de la arteria cerebral anterior y por encima de la arteria carótida interna.

El amplio espacio subaracnoideo que rodea a la porción orbitaria del nervio óptico se estrecha notablemente a su paso por el conducto óptico, lo que le hace imperceptible en este tramo en las imágenes ponderadas 
en T2 y ya en la porción intracraneal, el nervio óptico va cubierto sólo por piamadre y rodeado por el líquido cefalorraquídeo de la cisterna supraselar.

En los cortes coronales de RM (Fig. 31), el nervio óptico intracanalicular puede identificarse por su disposición medial a la apófisis clinoides anterior y lateral al seno esfenoidal. Los cortes axiales de RM (Fig. 29) muestran al nervio óptico en todo su recorrido: en la cisterna quiasmática cuando se trata de la porción intracraneal, en el interior del conducto orbitario, dentro del anillo tendinoso común o de Zinn en el vértice de la órbita y centrado en el interior del cono muscular cuando recorre el fondo orbitario.

El nervio óptico está constituido por fibras nerviosas mielinizadas por lo que exhibe en RM características de señal similares a las de la sustancia blanca cerebral.

El quiasma óptico, con su típica forma de " $X$ " aplanada está constituido por la unión de los dos nervios ópticos; normalmente mide 10 a $20 \mathrm{~mm}$ en sentido transversal, 4 a $13 \mathrm{~mm}$ de diámetro antero-posterior y 3 a $5 \mathrm{~mm}$ de diámetro cráneo-caudal.

El quiasma es fácilmente identificable por su intensidad de señal en las secciones de Resonancia Magnética (Fig. 29). Se sitúa por delante de la silla turca del esfenoides, ocupando el surco prequiasmático o un poco por detrás, cerca del diafragama selar. La porción de suelo del III ventrículo encefálico situada entre los recesos óptico e infundibular está formada por el quiasma óptico. Por detrás del quiasma se proyecta hacia abajo el tallo de la hipófisis y el túber cinereum. El quiasma establece así 
relaciones con estructuras anatómicas que pueden incidir sobre su patología, como la hipófisis y el círculo arterial de Willis.

De los extremos del quiasma óptico parten los tractos o cintillas ópticas que se extienden dorsolateralmente y ligeramente hacia arriba. Transcurren alrededor del túber cinereum, a ambos lados; pasan detrás de la sustancia perforada anterior, después corren por encima del uncus y circundan los pedúnculos cerebrales, por ambos lados, para terminar en el cuerpo geniculado lateral. Éste corresponde a un núcleo complejo de neuronas, constituido por una porción ventral y otra dorsal, siendo esta última la que recibe la mayor parte de los axones de la cintilla óptica. Sus diferentes tipos neuronales, representan las terceras neuronas de la vía óptica. La visión 3D de los tractos ópticos y del núcleo geniculado lateral se halla en las figuras correspondientes a la representación 3D de la vía óptica en su totalidad (Figs. 51 a 54).

Del cuerpo geniculado lateral parten los cilindroejes que tienen que llegar hasta la corteza cerebral del lóbulo occipital situada en torno a la cisura calcarina, formando las radiaciones ópticas o el tracto geniculocalcarino (Fig. 32). Estas fibras las observamos en las secciones de Resonancia Magnética potenciadas en T1 como imágenes de una señal más elevada que la sustancia gris. Estas fibras, en principio, caminan por las porciones retro y sublenticular de la cápsula interna, dirigiéndose primero hacia delante luego hacia fuera y hacia atrás, describiendo sobre el asta temporal del ventrículo lateral un arco de convexidad anterior correspondiente al asa de Meyer (Fig. 33). Se constituye así una amplia banda que recubre gran parte de las astas temporal y occipital del ventrículo lateral, de cuya cavidad están separadas por las fibras del 
tapetum, una fina capa de sustancia blanca derivada del fórceps mayor (Fig. 32). Finalmente, estas fibras se dirigen hacia atrás para alcanzar la corteza cerebral situada en torno a la cisura calcarina. Esta zona de la corteza occipital corresponde al área visual primaria (V1), área 17 de Brodmann o área estriada, situada por encima y por debajo de la cisura calcarina, con una morfología triangular de base posterior, hacia el polo occipital. La abundancia de estas fibras las hace fácilmente identificables en las secciones de resonancia magnética, correspondiendo a la estría de Gennari (Figs. 33 y 34 ).

La corteza de asociación visual, área V2, corresponden a las áreas a las que llega la información visual principalmente del área 17. El área preestriada (V2), área 18 de Brodmann, se sitúa por delante de la V1, extendiéndose, en forma de banda, por las tres caras del lóbulo occipital. El área 19 de Brodmann (V3), se sitúa por delante de la V2 y ocupa también parte de las tres caras del lóbulo occipital (Fig. 35).

Áreas extraestriadas situadas en los lóbulos temporal y parietal reciben conexiones directas de las áreas V1, V2 y V3.

\section{Sistema Oculomotor:}

Anexos al globo ocular existen unos músculos estriados y voluntarios que permiten al ojo realizar movimientos de orientación y exploración visual en todas las direcciones del espacio: verticales, horizontales, oblicuos y de convergencia, aislados o asociados a los movimientos de la cabeza y el cuello. 
Los movimientos oculares se caracterizan por ser conjugados, es decir, simultáneos y en la misma dirección en ambos ojos, para permitir la visión binocular, que dé lugar a una imagen de igual forma, tamaño, color, etc., y que, además, se perciba como única.

Los músculos extrínsecos del globo ocular, inervados por los pares craneales III, IV y VI, contrastan fácilmente con el tejido graso periorbitario, el cual aparece hiperintenso en las imágenes de resonancia magnética potenciadas en T1. Los músculos son visibles como estructuras de baja intensidad de señal, lo que facilitó su identificación para la reconstrucción 3D (Figs. 18 a 22).

Por sus inserciones en la superficie ocular, mantienen un ajustado equilibrio de fuerzas que tiran del ojo hacia atrás (músculos rectos) y hacia delante (músculos oblicuos). Todos los músculos extrínsecos, excepto el oblicuo inferior, tienen su origen en el anillo tendinoso común, que rodea el agujero óptico y la parte medial y más ancha de la fisura orbitaria superior o hendidura esfenoidal (Figs. 36 y 37). Este anillo de Zinn está constituido por dos semicírculos: superiormente, el tendón de Lockwood, constituye el origen del músculo recto superior; inferiormente, el tendón de Zinn que da origen a los músculos rectos medial, inferior y lateral.

El anillo divide a la fisura orbitaria superior en tres espacios: uno superolateral por donde atraviesan los nervios frontal, lagrimal y troclear; otra central, por donde pasan el nervio nasociliar, las ramas superior e inferior del nervio motor ocular común, el nervio abducens y la vena oftálmica superior; y otra inferior que contiene a la vena oftálmica inferior. 
Los cuatro músculos rectos (superior, inferior, lateral y medial) se dirigen desde dicho anillo hacia delante (Figs. 36, 37, 41 a 44). En los primeros $5 \mathrm{~mm}$ de su longitud, los músculos rectos no están individualizados sino inmersos plenamente en el anillo de Zinn (Fig. 38). A unos $8 \mathrm{~mm}$ por delante del conducto óptico, los músculos rectos se separan y aparecen ya como estructuras individualizadas, a la vez que se van haciendo más anchos, terminando insertándose en la esclerótica, por delante del ecuador del globo ocular (Figs. 41 a 44), después de haber perforado la vaina o cápsula de Tenon, que envuelve al globo ocular. En las imágenes de RM, las inserciones tendinosas de los músculos rectos sobre el globo ocular no pueden diferenciarse nítidamente del tejido escleral (Fig. 22).

En las secciones sagitales y axiales de RM, las imágenes muestran que la trayectoria de los músculos rectos no es realmente rectilínea, como previamente se les suponía sino que está curvada. Estos datos son más elocuentes cuando se observan el modelo anatómico en 3D (Figs. 36 y 38 a 46).

Los músculos rectos van envueltos en vainas de tejido conectivo unidas entre sí por tabiques o septos conectivos que se funden anteriormente con la capsula de Tenon. Es de destacar que en la zona intermedia de la órbita, el septo intermuscular situado entre los músculos recto superior y recto lateral tiene en la sección coronal un grosor y una intensidad de señal muy similares a la de los músculos extraoculares (Fig. 22). Además, en esta zona orbitaria, los músculos rectos más los tabiques intermusculares configuran un cono completo que circunda al nervio 
óptico, a la arteria oftálmica y a ciertas ramas nerviosas señaladas con anterioridad.

En íntima relación con el músculo recto superior se sitúa el elevador del párpado superior (Fig. 39), que discurre desde el vértice de la órbita, donde se inserta en el ala menor del esfenoides y en parte del tendón de Lockwood, hasta el párpado superior deslizándose sobre el músculo recto superior (Fig. 40) y terminando en forma de abanico, mediante una aponeurosis, en diversas estructuras del párpado superior.

El músculo oblicuo superior se origina en el ala menor del esfenoides, superior y medialmente al tendón de Zinn (Fig. 45); camina hacia delante por la arista superointerna de la órbita hasta la fosita troclear dónde se inserta un ligamento que permite al músculo reflejarse y cambiar de dirección hacia fuera y hacia atrás, metiéndose por debajo del recto superior e insertándose en la esclerótica por detrás del ecuador del globo ocular (Fig. 45).

El músculo oblicuo inferior es una cinta muscular aplanada que se origina en el ángulo inferointerno de la órbita, junto al conducto nasolagrimal (Fig. 46), dirigiéndose hacia fuera y atrás, cruza bajo el músculo recto inferior y acaba insertándose en la esclerótica, en el cuadrante inferolateral del globo ocular, por detrás del ecuador, caudal al músculo recto lateral (Fig. 46).

Los músculos extraoculares están inervados por los pares craneales III, IV y VI. Estos nervios al entrar en la órbita se ramifican en numerosos fascículos que discurren hacia delante, incluidos entre fibras musculares para terminar inervando a los músculos en su tercio posterior a partir de 
sus caras intraconales. Las diminutas ramificaciones y los fascículos de los nervios motores no pueden ser visualizados en las RM. Sólo los troncos nerviosos a su paso por el vértice orbitario y la rama inferior del III par destinada al músculo oblicuo inferior pueden ser visualizados en la RM de alta resolución.

El nervio oculomotor, III par craneal o nervio motor ocular común, se puede identificar con facilidad, en las tres incidencias. Emerge de la región interpeduncular del mesencéfalo (fig. 47), pasa entre las arterias cerebelosa superior y cerebral posterior atravesando la cisterna interpeduncular donde se dispone adyacente a la arteria comunicante posterior. Después, el III par perfora la duramadre en la parte superior del clivus y ya incluido en la lámina fibrosa del seno cavernoso se relaciona con el nervio troclear, pasando primero por encima de este nervio y luego, justo por detrás de la fisura orbitaria superior, lo cruza y se sitúa bajo el IV par a la vez que se divide en dos ramas (superior e inferior), que atraviesan la porción central de la fisura orbitaria superior, entrando así en la órbita. La división superior del III par termina inervando al músculo recto superior y al elevador del párpado superior. La división inferior sigue un trayecto medial e inferior para inervar a los músculos rectos medial e inferior. También de este tronco se desprende una larga y gruesa rama destinada al músculo oblicuo inferior.

El nervio troclear, IV par craneal o nervio patético (Fig. 48), emerge del tronco del encéfalo por la cara dorsal del mesencéfalo, bajo los colículos inferiores, corre a lo largo del borde libre de la tienda del cerebelo y contornea los pedúnculos cerebrales, pasando entre las arterias cerebelosa superior y cerebral posterior, hasta entrar en el borde 
lateral del seno cavernoso donde se relaciona con el III par, según se describió anteriormente. Cuando sale del seno cavernoso atraviesa la porción superolateral de la fisura orbitaria superior penetrando en el vértice orbitario y cruzando por encima de las inserciones de los músculos recto superior y elevador del párpado superior aborda la cara lateral del músculo oblicuo superior a unos $10 \mathrm{~mm}$ del vértice orbitario.

Al ser el IV par un nervio muy delgado y de textura delicada (Fig. 48), es muy difícil observarlo e identificarlo con certeza, ya que puede confundirse con el borde libre de la tienda del cerebelo. En las secciones axiales, se visualizó el nervio en su origen aparente, por debajo de los colículos inferiores, en el trayecto intracisternal y en la pared del seno cavernoso con secuencias potenciadas en T1 y T2. Dentro de la órbita, con secuencias T1, se identificó al IV par con una señal hipointensa e íntimamente relacionado con el músculo oblicuo mayor.

El nervio abducens, VI par craneal o nervio motor ocular externo (Fig. 49), tiene su origen aparente en el surco bulbo protuberancial, cerca de la línea media, inmediatamente por debajo de la convergencia de las dos arterias vertebrales; enseguida asciende por la superficie ventral de la protuberancia, atraviesa la duramadre y pasa sobre el vértice del peñasco a través del conducto de Dorello (conducto osteofibroso situado bajo el ligamento petroclinoideo de Gruber). Después, el VI par entra y atraviesa el interior del seno cavernoso (Fig. 50), relacionándose con la arteria carótida interna, colocándose primero por fuera y luego ínferolateralmente a la misma. La entrada del nervio en la órbita tiene lugar a través de la porción central de la fisura orbitaria superior; a continuación, se hace intraconal atravesando el anillo labrado en el tendón de inserción 
posterior del músculo recto lateral y tras pegarse a su cara medial acaba por penetrarlo e inervarlo.

Al igual que el IV par, el nervio abducens es muy difícil de identificar en las imágenes de RM, debido a su finura. Fue localizado en cortes axiales, en su origen aparente $\mathrm{y}$ en su trayecto intracisternal, con secuencias potenciadas en T2. Ya en el interior de la órbita se hizo patente en las secciones axiales de RM, como una imagen puntiforme, hipointensa en relación con el músculo recto lateral.

El trayecto de los tres pares craneales, desde su origen aparente en el tronco del encéfalo hasta su terminación en los músculos extraoculares, así como las relaciones que mantienen entre sí los tres nervios, puede seguirse en las reconstrucciones tridimensionales (fig. 50), con la posibilidad de analizar su trayecto con o sin referencia al hueso esfenoides (Fig. 50). Las imágenes 3D muestran el largo trayecto intracraneal que tiene el IV par con relación al III y VI (Fig. 50) y permite comprender la predisposición que tiene este nervio a lesionarse en los traumatismos cefálicos directos.

\section{Interface Gráfico de usuario:}

Las reconstrucciones tridimensionales efectuadas de todas estas estructuras anatómicas integrantes de la vía óptica (Figs. 51 y 52) y del sistema oculomotor (Figs. 53 y 54) embebidas en los datos volumétricos de resonancia magnética, nos permiten valorar y comprender de forma clara e intuitiva la morfología del conjunto de elementos anatómicos que componen el sistema óptico y oculomotor ya que el examen individual de 
las imágenes de los distintos cortes que componen una secuencia de resonancia magnética resulta muy dificultoso. En este sentido, nuestra aplicación informática buscó constituirse en una metodología adecuada para la visualización 3D, teniendo como referencia la sección de resonancia magnética en los tres planos del espacio, lo que facilita su valoración anatómica, haciendo uso de las capacidades gráficas avanzadas que hoy en día ofrecen los ordenadores.

El interface gráfico de usuario se diseñó para que fuese de fácil manejo e intuitivo y permitiera la visualización de las estructuras anatómicas en tres dimensiones a petición del usuario, teniendo como patrón de referencia las secciones de resonancia magnética en los tres planos del espacio (coronales, axiales y sagitales). Posee la opción de activar o desactivar la visualización de cada una de ellas, ofreciéndonos información sobre la estructura anatómica 3D seleccionada.

A continuación, describiremos brevemente las principales opciones del funcionamiento y manejo del programa.

El interface de usuario generado para el estudio de la vía óptica y la musculatura extrínseca del globo ocular permite representar e interactuar con 2 tipos de elementos visuales: Planos y Modelos (Figs. 55 y 56).

Todas las interacciones con los elementos de la escena visual (rotaciones, traslaciones, zoom y selección) se realizan situando el cursor sobre el visor y desplazando el ratón. 


\section{Rotaciones:}

Para rotar la imagen del visor, se mantendrá pulsado el botón principal (izquierdo) del ratón mientras desplazamos el cursor sobre la pantalla.

\section{Traslaciones:}

Para trasladar la imagen del visor en el plano de la pantalla, se deberán mantener pulsados los dos botones del ratón mientras desplazamos este periférico.

\section{Zoom:}

Para ampliar o reducir el tamaño de la imagen que se muestra en el visor (Fig. 51), es necesario desplazar el ratón, mientras se mantiene presionado su botón secundario, hacia arriba (ampliar) o hacia abajo (reducir).

\section{Selección:}

Haciendo clic en el visor, sin mover el ratón, se seleccionará el plano modelo sobre el que se pulse.

El plano seleccionado se puede desplazar a lo largo de su eje manteniendo pulsada la tecla mayúsculas mientras desplaza el ratón por la pantalla sin mantener pulsado ningún otro botón del ratón. 
El color de fondo del Visor por defecto es negro, pero puede cambiarse en la pantalla de Opciones (Figs. 57 y 58). Lo mismo puede hacerse con el color de la línea y de la rejilla.

\section{$\underline{\text { Planos }}$}

Corresponde a la pantalla en la que interaccionan el Visor con los controles necesarios para manejar las imágenes seccionales de RM que se presentan en el visor (Fig. 59).

Existen tres planos de orientación y visualización: Plano Sagital, Plano Axial y Plano Coronal (Fig. 59).

Cada plano posee un control de selección para activar o desactivar su visibilidad además de una barra de desplazamiento que permite cambiar el nivel de corte. También podremos cambiar la posición del plano seleccionado, moviendo el cursor horizontalmente sobre el visor, mientras se pulsa Mayúsculas, sin mantener pulsado ningún botón del ratón.

El último plano desplazado aparece enmarcado en el color indicado en Opciones; por defecto estará en azul.

En esta sección también se podrá activar una rejilla en cada uno de los planos marcando el cuadro de selección de la pestaña Rejilla. La distancia entre celdas de esta rejilla puede controlarse desde el control tamaño, seleccionando uno de la lista desplegable, oscilando entre 1 y 8 mm. (Fig. 60). 


\section{Modelos}

Pantalla en la que interaccionan el Visor y su configuración. El botón Modelos controla las estructuras anatómicas a representar en tres dimensiones (3D).

Los botones Mostrar Todos y Ocultar Todos permiten, de una forma rápida y conjunta, ver cómo se integran perfectamente los modelos en los planos de corte (si éstos están visibles) así como hacer desaparecer a la vez todos los modelos 3D del visor.

Podremos en la configuración, seleccionar / deseleccionar los modelos de forma independiente e ir visualizándolos según la selección realizada al efecto en el apartado del desplegable donde se podrá observar la lista de todas las estructuras (modelos 3D) disponibles, todas ellas ordenadas alfabéticamente (Fig. 55). El cuadro de selección Visible permite activar o desactivar la visibilidad del modelo seleccionado, que aparecerá enmarcado en su color. Seleccionando sobre el color podremos modificar éste. Pueden seleccionarse sucesivamente varios modelos para su visualización simultánea.

El cuadro de texto inferior muestra una breve descripción en relación con el modelo-3D seleccionado (Fig. 56).

\section{Cámaras}

Existen tres Vistas Predefinidas: Coronal, Sagital y Axial, que orientan la visión de la escena en el plano indicado. 
La vista resultante de realizar rotaciones, traslaciones o zoom puede ser almacenada mediante fichero a través del botón al efecto (indicado con un icono de cámara), que permite guardar la escena representada en el visor en un fichero en formato bitmap (.bmp).

\section{Opciones adicionales}

Otras opciones complementarias pueden efectuarse en nuestro desarrollo informático, entre ellas cabe destacar:

$\checkmark$ Modificar el color de fondo del visor: por defecto tendremos el color negro (Figs. 57 y 58 ).

$\checkmark$ Modificar el color de la selección en los planos: por defecto es de color verde.

$\checkmark$ Modificar el color de la selección en la rejilla: por defecto es de color gris.

$\checkmark$ Limitar las rotaciones tanto en el eje $X$ (horizontal) como en el eje $Y$ (Vertical).

$\checkmark$ Mostrar y ocultar el texto técnico de la aplicación que hace referencia a la imagen radiológica y a los grados de rotación de la misma.

$\checkmark$ Restaurar los valores originales del visor, recuperando los colores originales de modelos, fondo, marco y rejilla, ocultando los planos, mostrando todos los modelos y colocando la cámara en su posición original. 


\section{Valoración del modelo informático:}

El modelo informático fue testado y valorado por 60 personas $(n=60)$, de las cuales cincuenta pertenecían al campo profesional de la oftalmología (oftalmólogos y residentes) y otras diez eran estudiantes de 5o curso de la licenciatura de Medicina. Para ello, se llevó a cabo una encuesta de satisfacción del programa informático con el objetivo de valorar y comprobar su eficacia.

La encuesta se efectuó utilizando la escala de Liker, en los términos reflejados en la tabla que se adjunta en la siguiente página.

Valore el grado en que está de acuerdo con las siguientes cuestiones

$(1$ = Totalmente en desacuerdo, 5 = totalmente de acuerdo $)$ :

\begin{tabular}{|c|c|c|c|c|c|c|}
\hline $1^{\mathrm{a}}$ & $\begin{array}{l}\text { Considero que el programa informático es útil para mi formación } \\
\text { médica }\end{array}$ & 1 & 2 & 3 & 4 & 5 \\
\hline $2^{\mathrm{a}}$ & Me facilita la identificación de estructuras anatómicas por RM & 1 & 2 & 3 & 4 & 5 \\
\hline $3^{\mathrm{a}}$ & El interface del programa, lo considero de fácil manejo y atractivo & 1 & 2 & 3 & 4 & 5 \\
\hline $4^{\mathrm{a}}$ & $\begin{array}{l}\text { Me proporciona un buen conocimiento anatómico de la vía óptica y } \\
\text { sistema oculomotor }\end{array}$ & 1 & 2 & 3 & 4 & 5 \\
\hline $5^{\mathrm{a}}$ & $\begin{array}{l}\text { Las consideraciones descritas en cada estructura anatómica son } \\
\text { suficientes y complementan la imagen }\end{array}$ & 1 & 2 & 3 & 4 & 5 \\
\hline $6^{\mathrm{a}}$ & $\begin{array}{l}\text { La visualización espacial y en 3D de las estructuras anatómicas me } \\
\text { facilitan su comprensión }\end{array}$ & 1 & 2 & 3 & 4 & 5 \\
\hline $7^{\mathrm{a}}$ & Este procedimiento informático aumenta mi motivación al estudio & 1 & 2 & 3 & 4 & 5 \\
\hline $8^{\mathrm{a}}$ & $\begin{array}{l}\text { Recomendaría, para estudiar la anatomía, este recurso adicional de } \\
\text { aprendizaje autónomo }\end{array}$ & 1 & 2 & 3 & 4 & 5 \\
\hline
\end{tabular}


Las medias de los datos obtenidos que aparecen en la gráfica, reflejan la valoración muy positiva que los usuarios tienen de esta aplicación informática, mostrando un alto grado satisfacción con el desarrollo didáctico empleado.

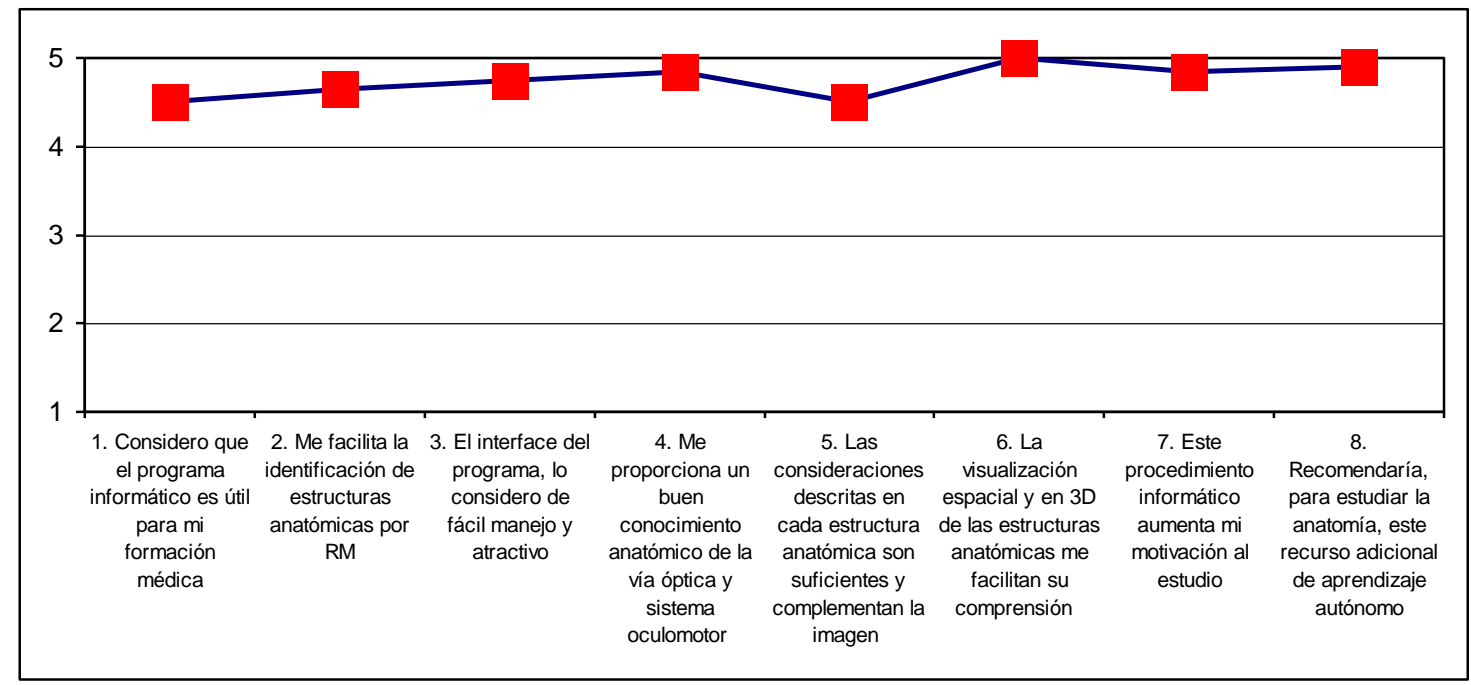

La mayor parte de los encuestados, manifestaron que el empleo de este recurso informático, como material de apoyo y complementario a su proceso de formación médica, ha supuesto una facilidad para mejorar los resultados de la evaluación de los conocimientos adquiridos durante su proceso formativo; probablemente debido a que estos sistemas de consulta interactivos, motivan al estudio por tratarse de medios muy dinámicos y atractivos para los usuarios.

\section{Iconografía de Resultados:}




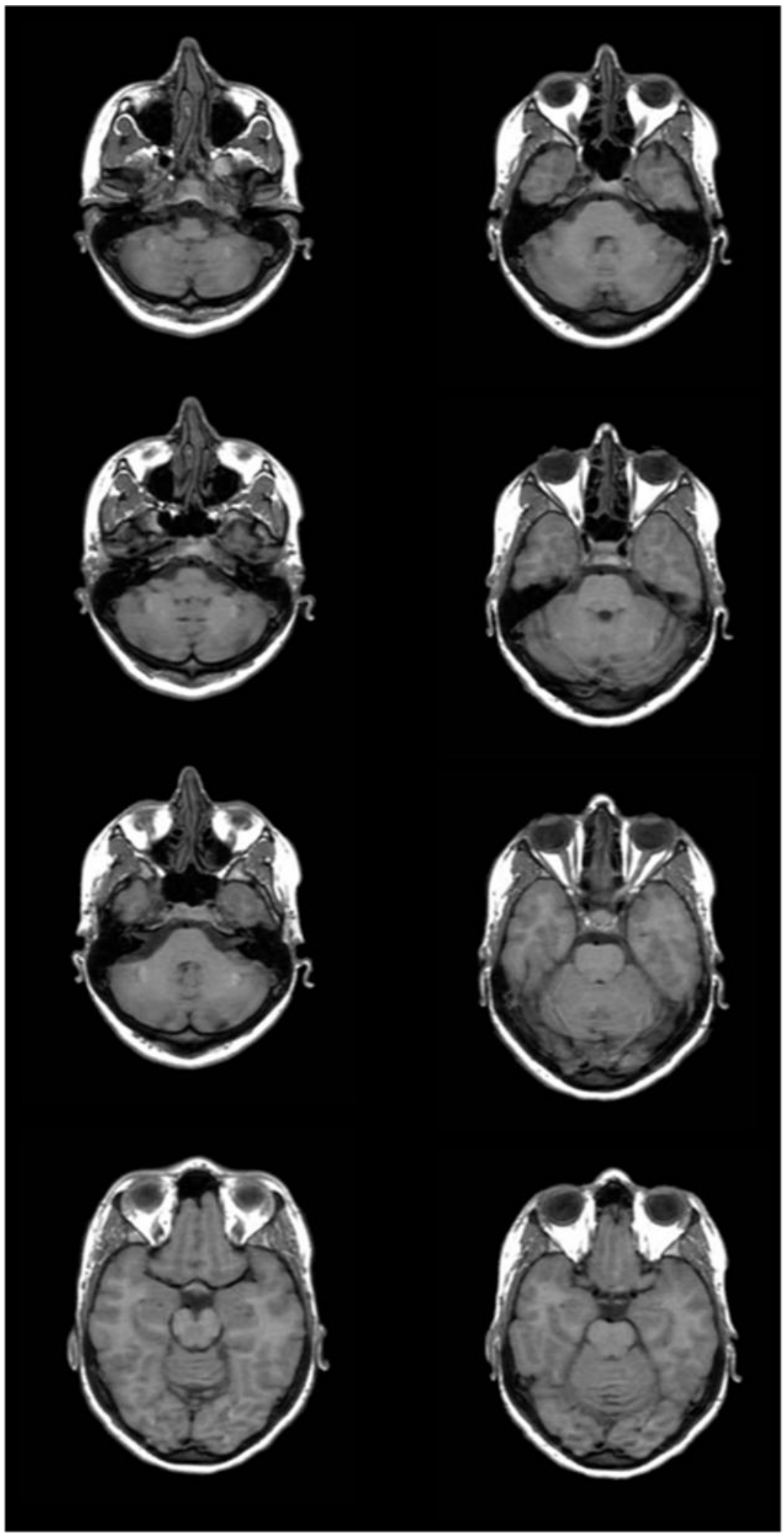

Figura 18.- Secciones axiales seriadas de Resonancia Magnética para el estudio global de la vía óptica y musculatura extrínseca del globo ocular 

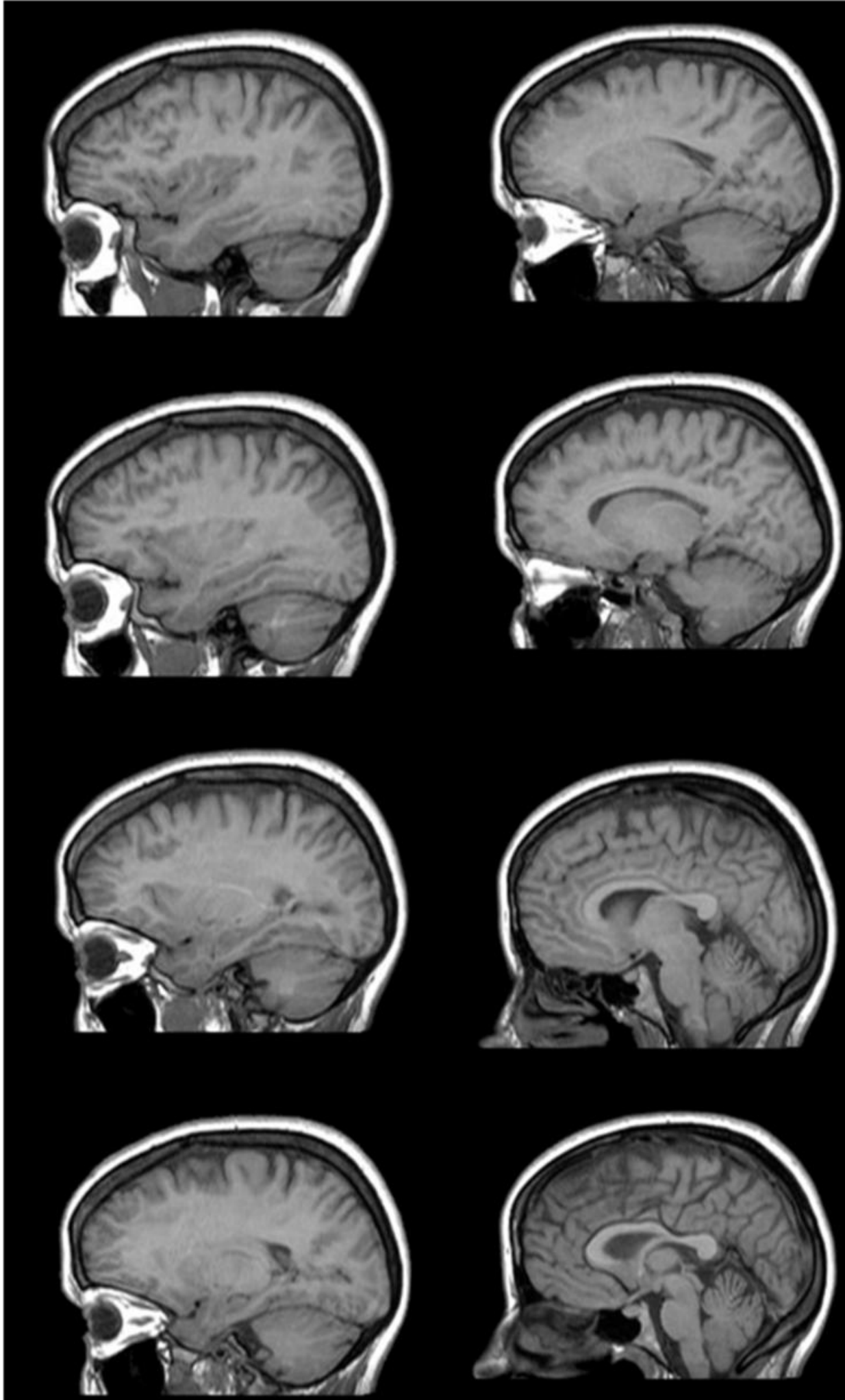

Figura 19.- Secciones sagitales seriadas de Resonancia Magnética para el estudio global de la vía óptica y musculatura extrínseca del globo ocular 

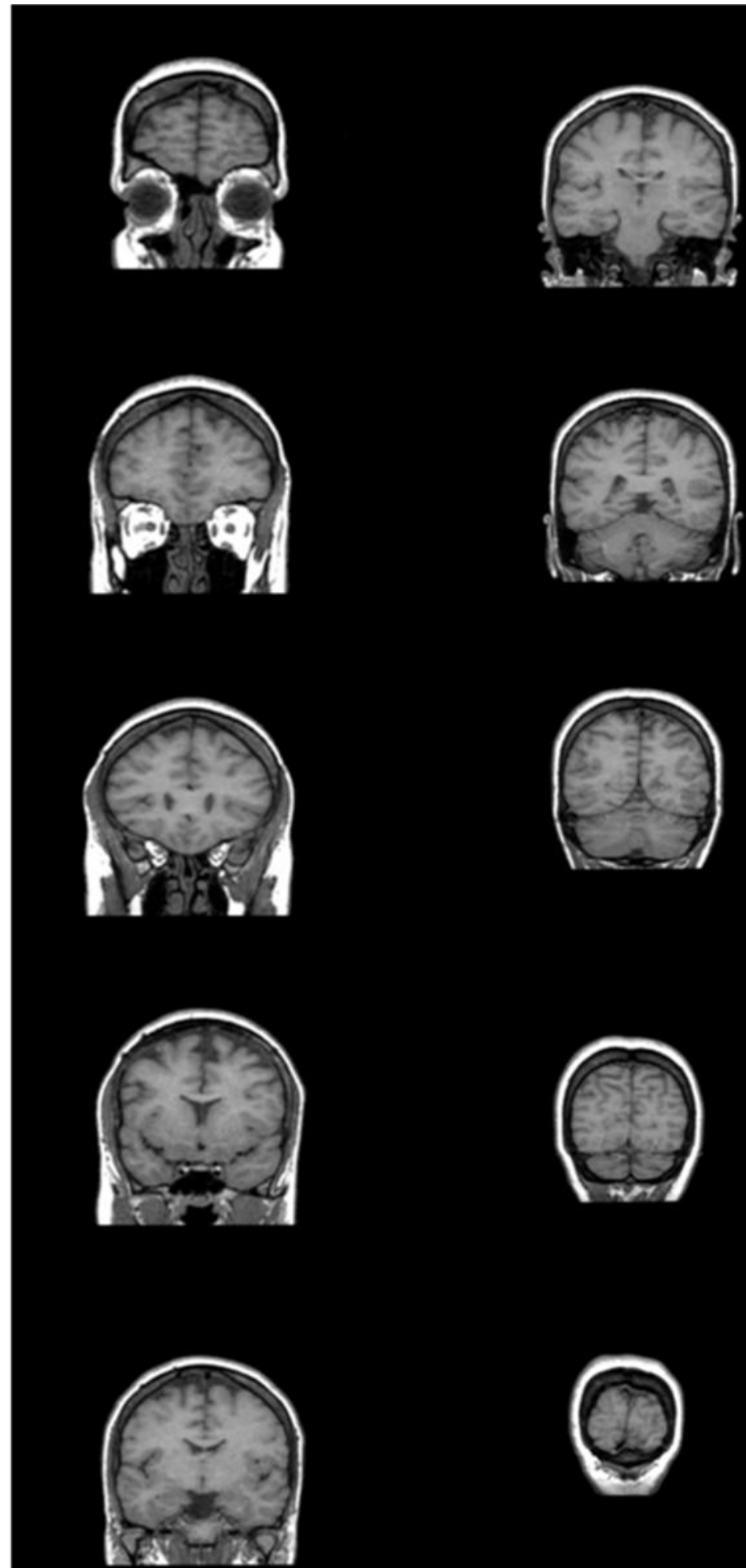

Figura 20.- Secciones coronales seriadas de Resonancia Magnética para el estudio global de la vía óptica y musculatura extrínseca del globo ocular 


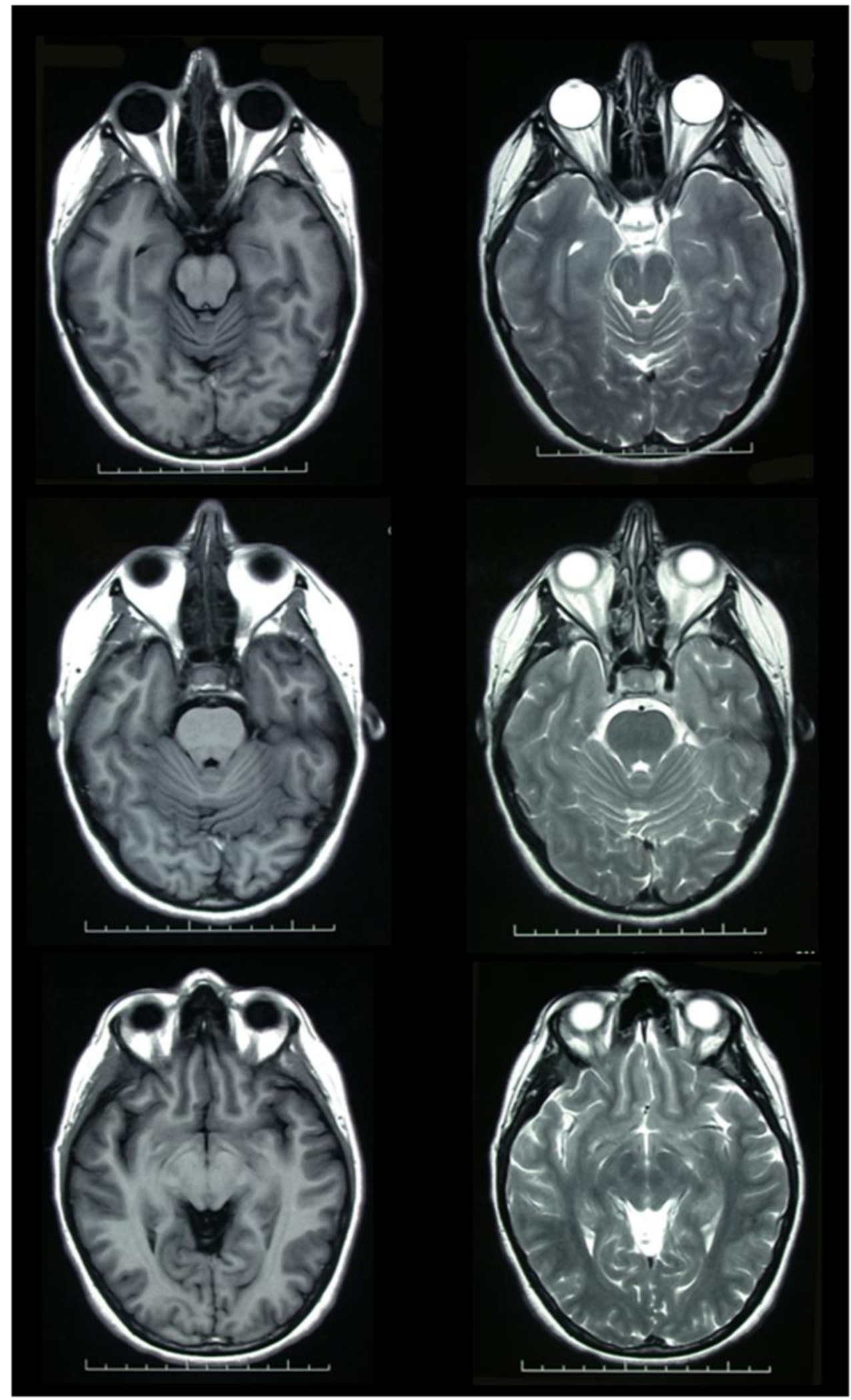

Figura 21.- Secciones axiales seriadas de Resonancia Magnética ponderadas en T1 (columna izquierda) y T2 (columna derecha). 


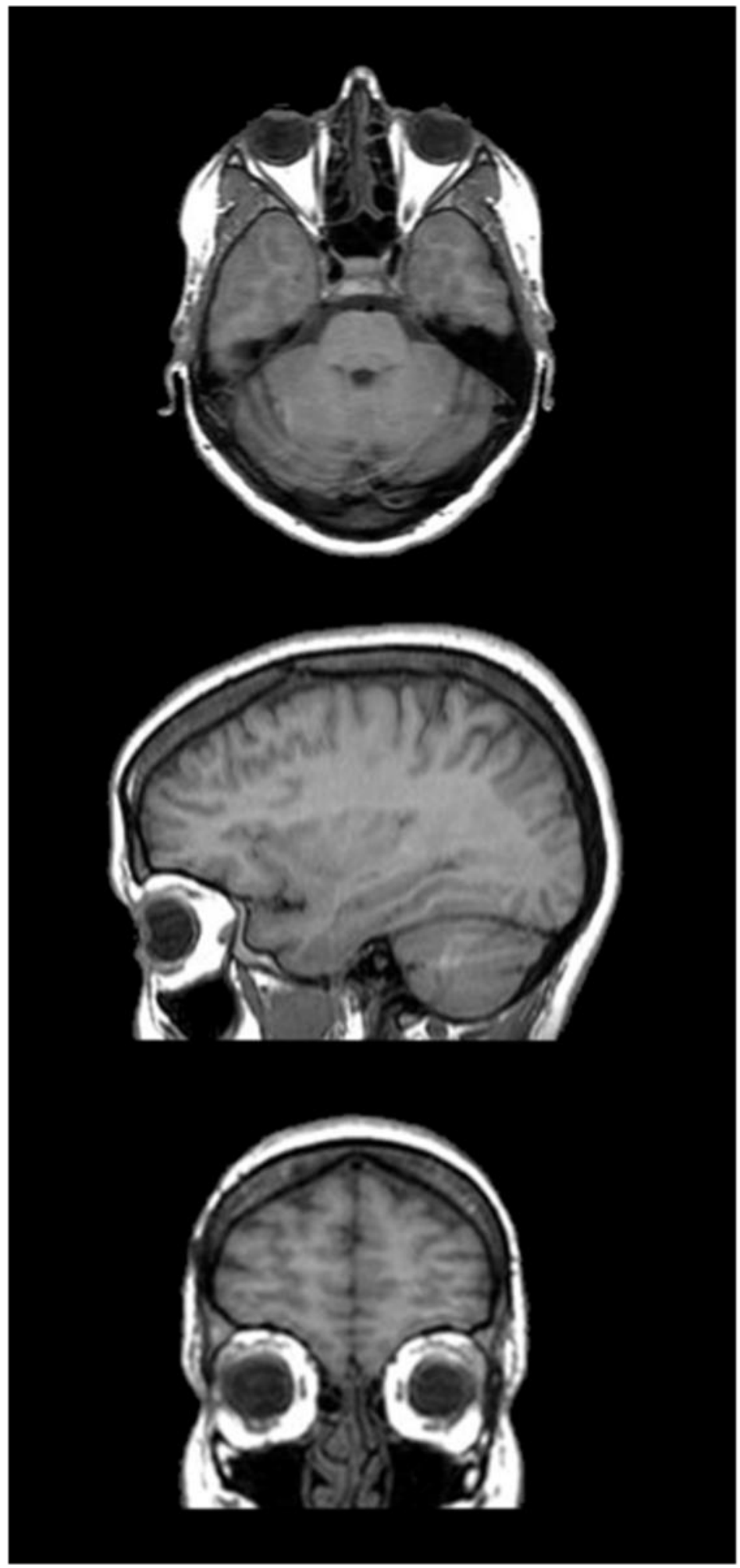

Figura 22.- Imágenes de Resonancia Magnética, secciones axial, sagital y coronal, ponderadas en T1, en las que se aprecian una buena señal para el estudio morfológico de la órbita y estructuras de la musculatura extraocular, excepto para su inserción escleral. 


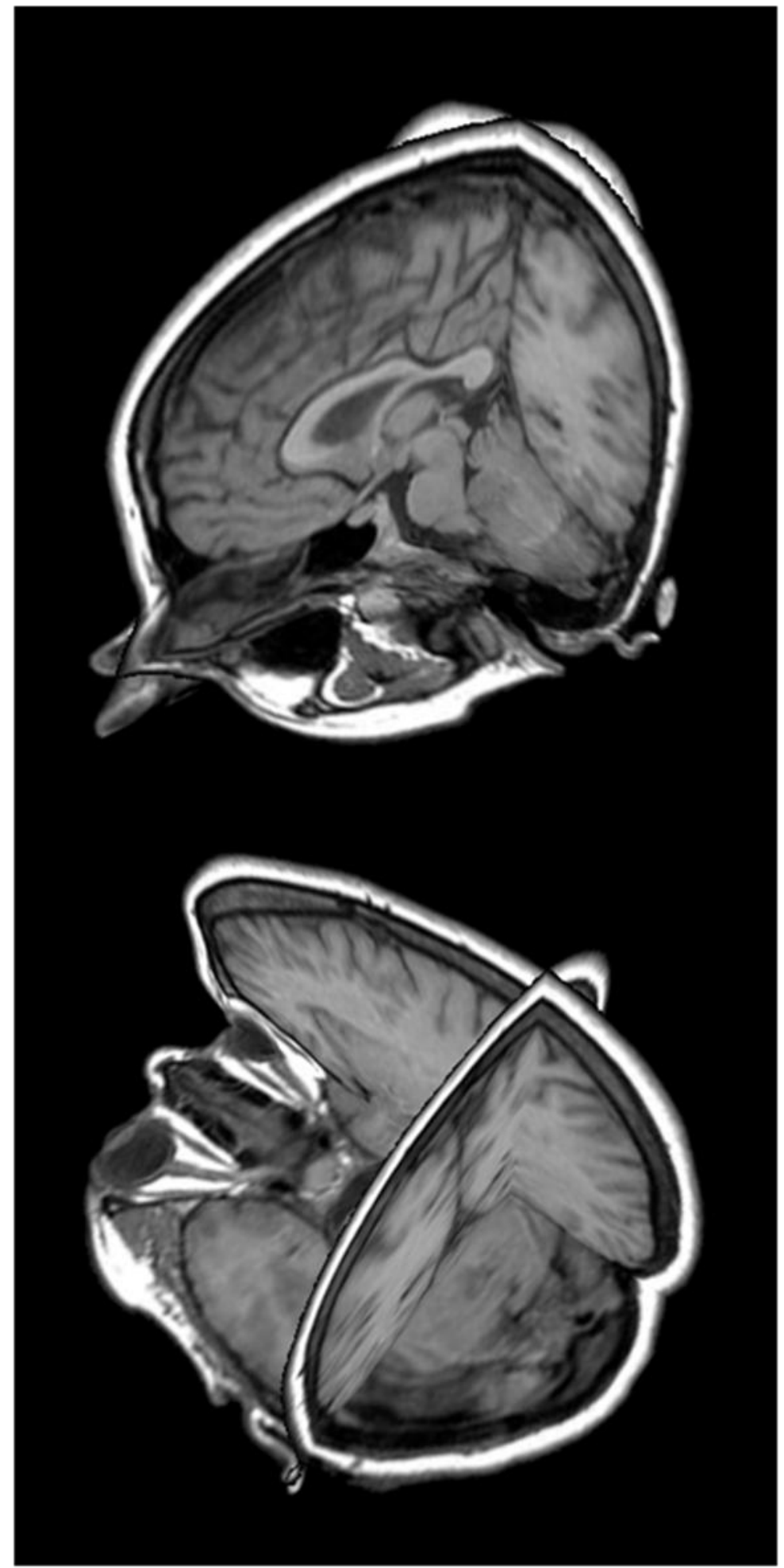

Figura 23.- Visualización de los tres planos de corte, simultáneamente, para su análisis en cualquier posición espacial, según la voluntad del usuario, permitiéndonos practicar un barrido seccional de cada uno de los planos, para el estudio morfológico integral. 


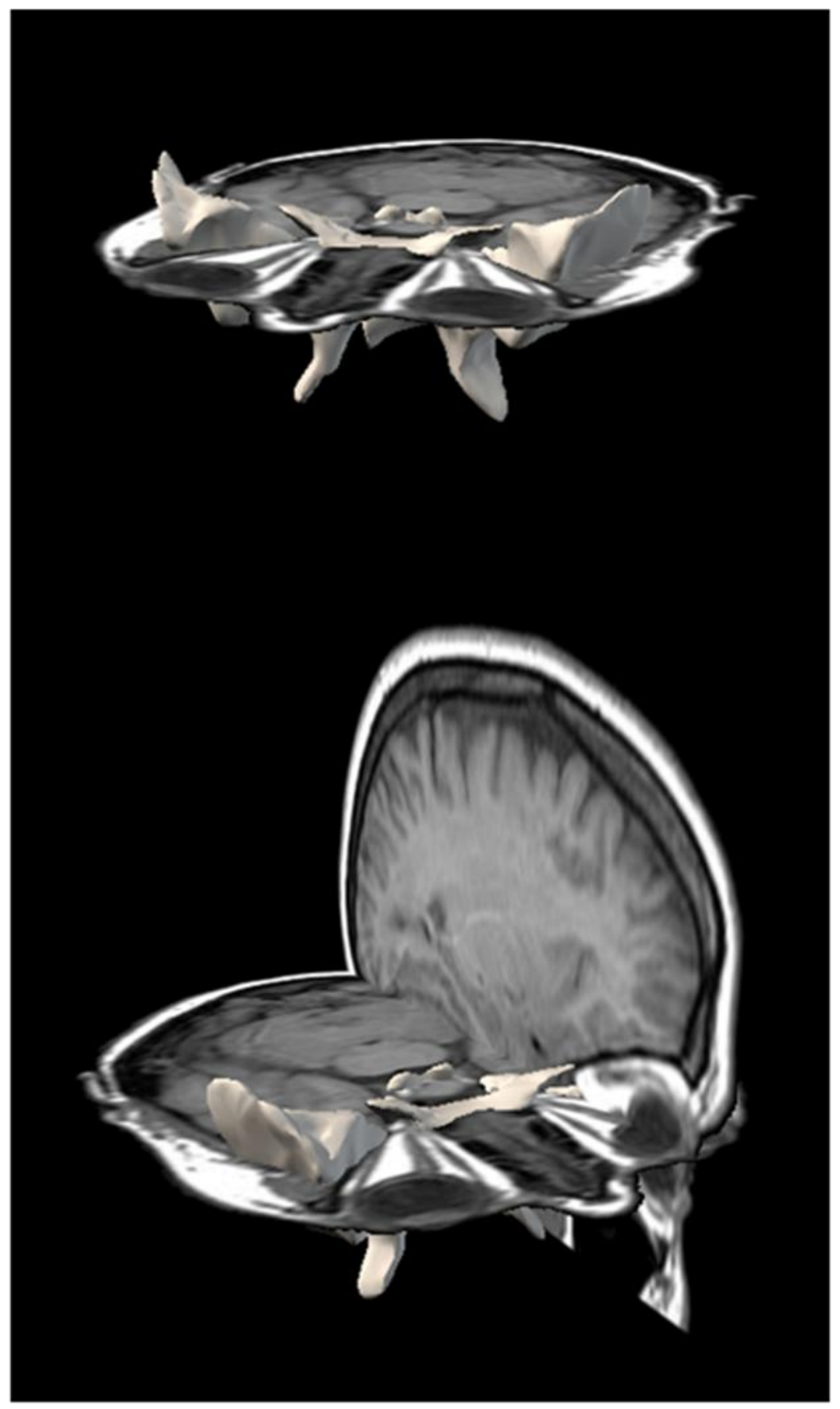

Figura 24.- Visualización de secciones de Resonancia Magnética, interpolado con la reconstrucción tridimensional del hueso esfenoides, obtenido desde la técnica de tomografía computarizada, lo que nos permite valorar las relaciones que mantiene este hueso con la órbita y vía óptica. 


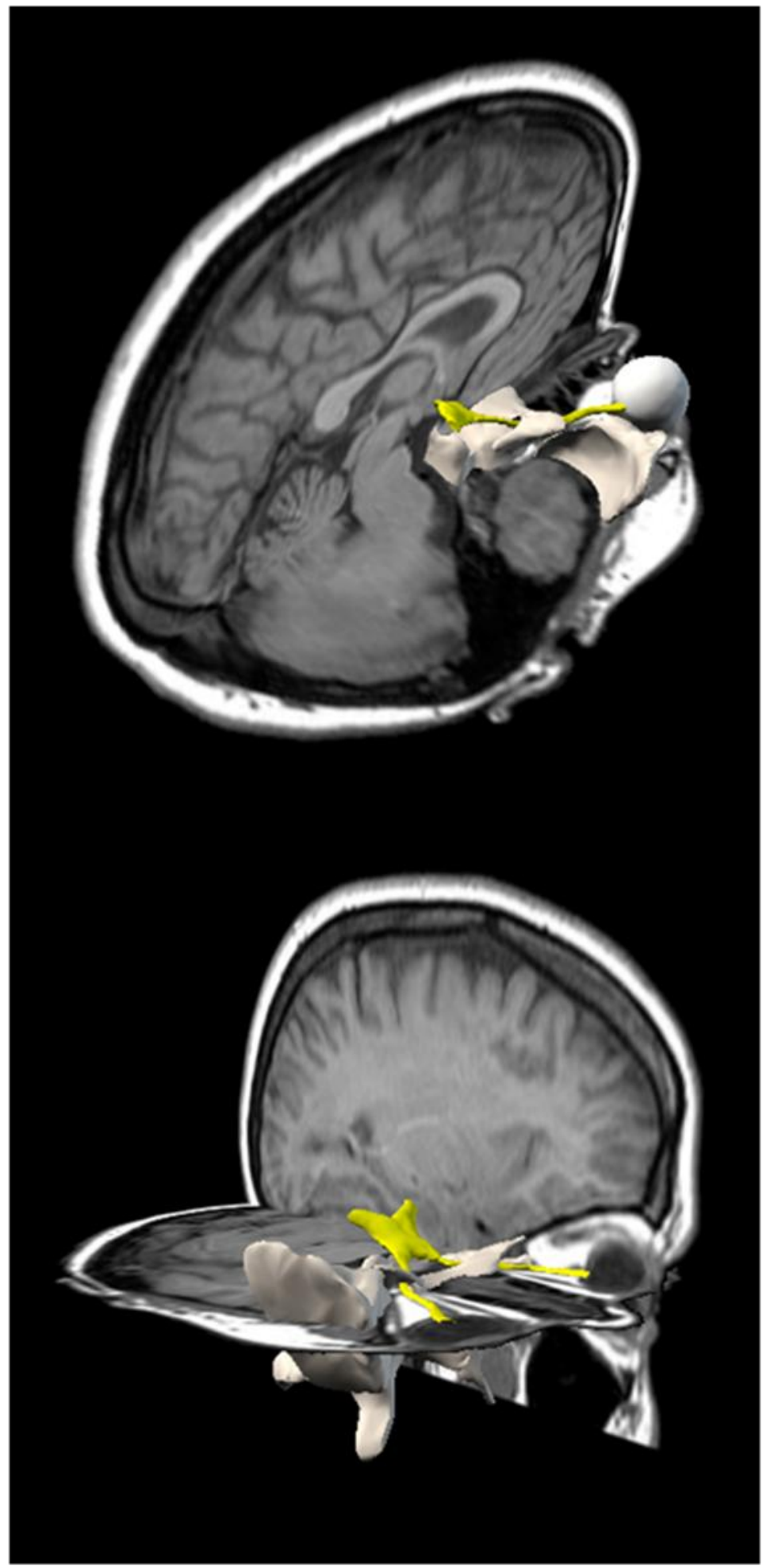

Figura 25.- Imágenes de secciones de Resonancia Magnética, interpolado con la reconstrucción tridimensional del hueso esfenoides, obtenido desde la técnica de tomografía computarizada, que permite visualizar analizar las relaciones del nervio óptico con el hueso esfenoides, y la unión de ambos nervios para formar el quiasma óptico. 


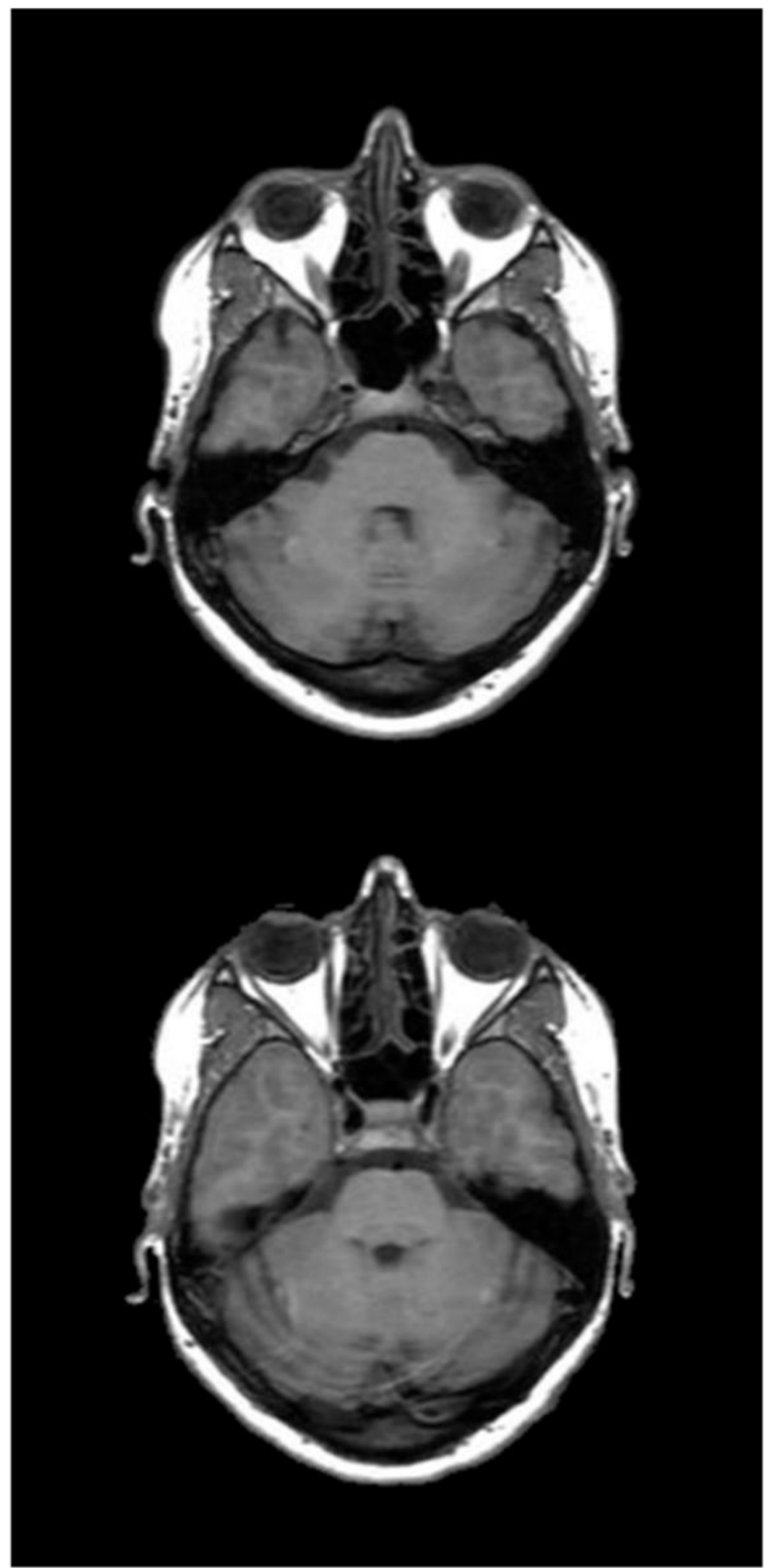

Figura 26- Imágenes axiales de Resonancia Magnética, que muestran la porción intracavernosa de la arteria carótida interna y el ligamento petroclinoideo de Gruber. 


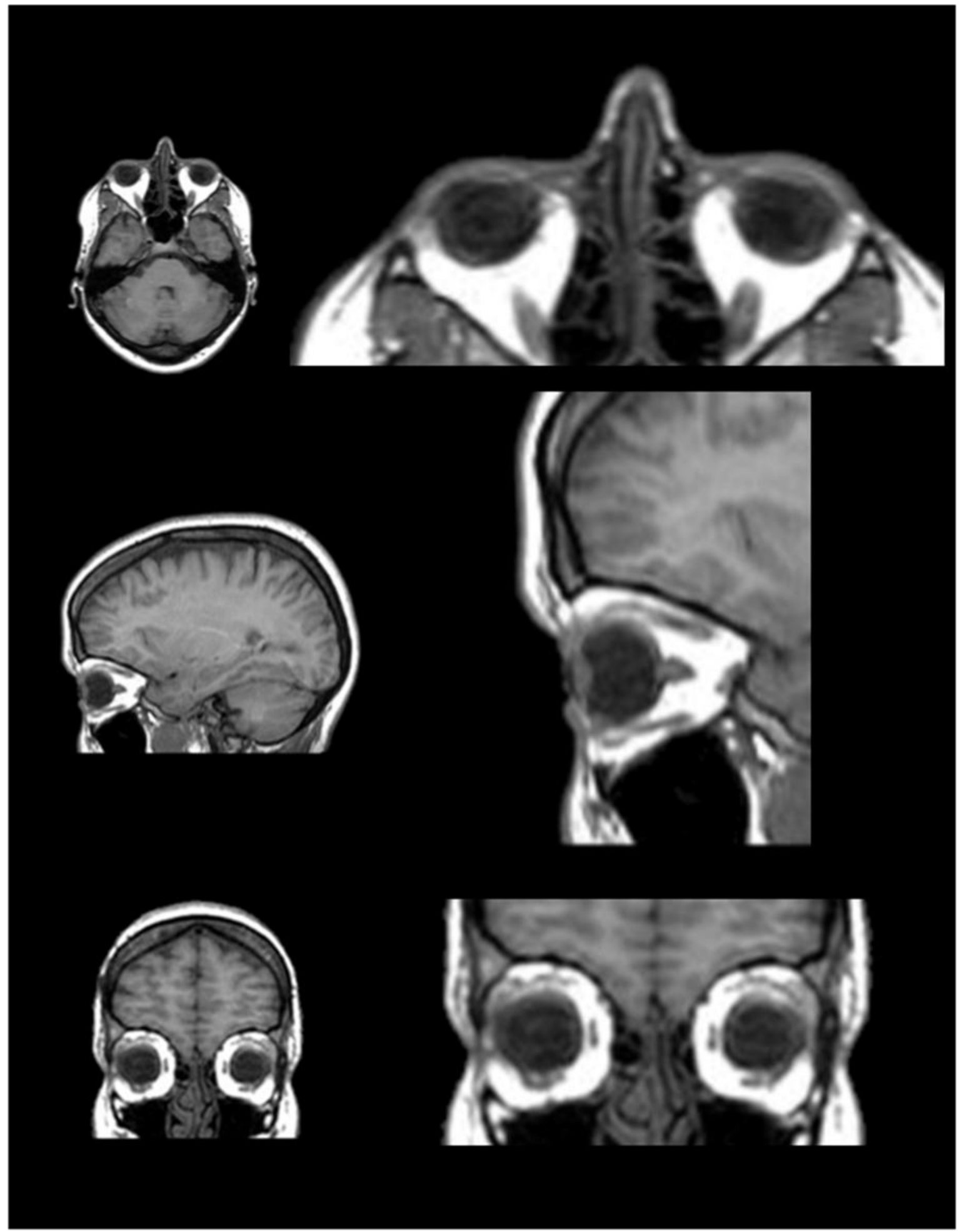

Figura 27.- Imágenes de RM en los tres planos del espacio, donde se visualiza, en el interior de la órbita, las principales estructuras del globo ocular, así como las secciones de la musculatura extrínseca, resal tando sobre la densidad de la grasa periorbitaria. 


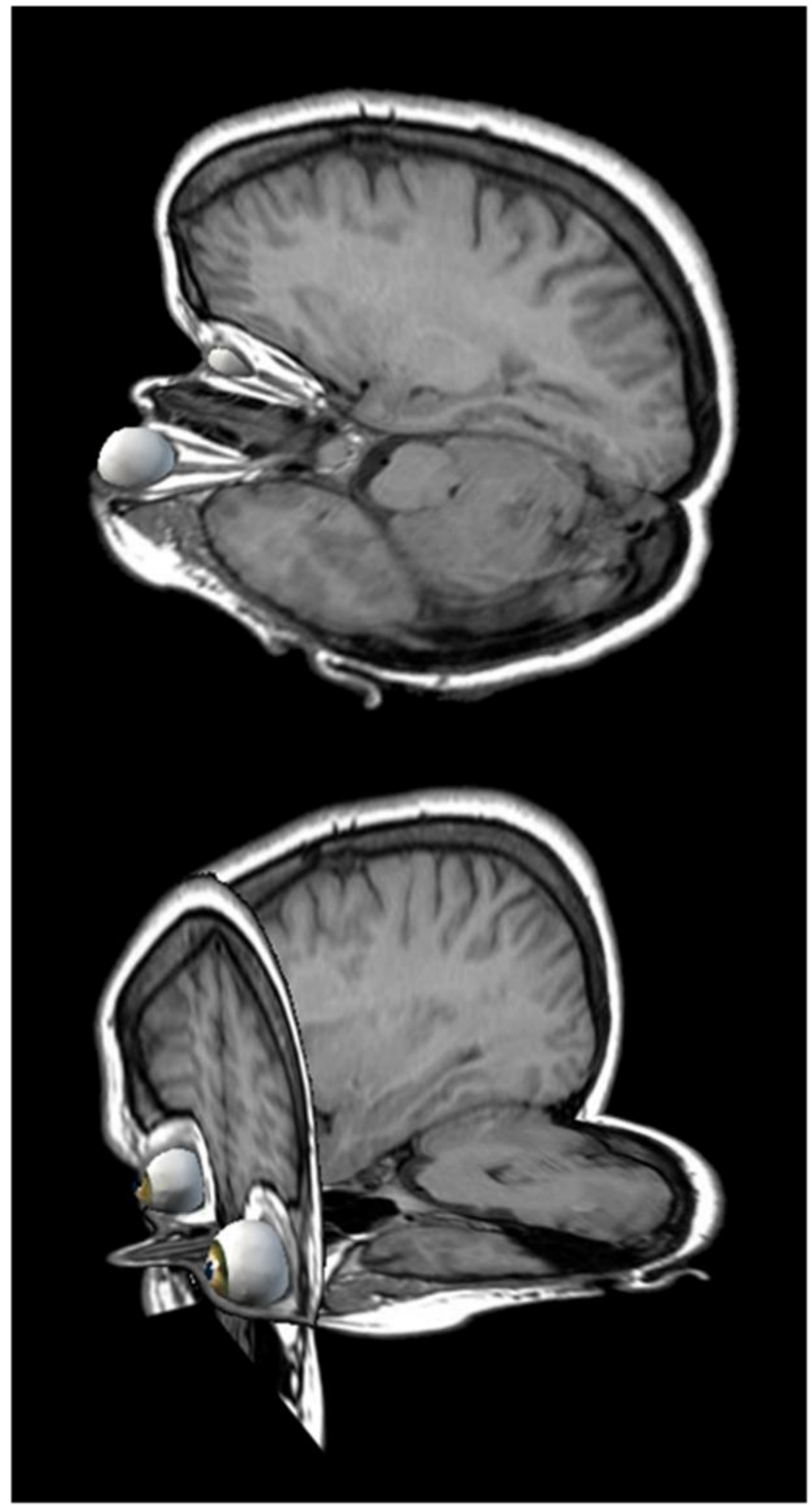

Figura 28.- Visualización tridimensional del globo ocular, en distintas posiciones espaciales, embebido en secciones de resonancia magnética, en diferentes planos de corte. En la imagen superior y partiendo del polo posterior del globo ocular, se aprecia la salida del nervio óptico. 


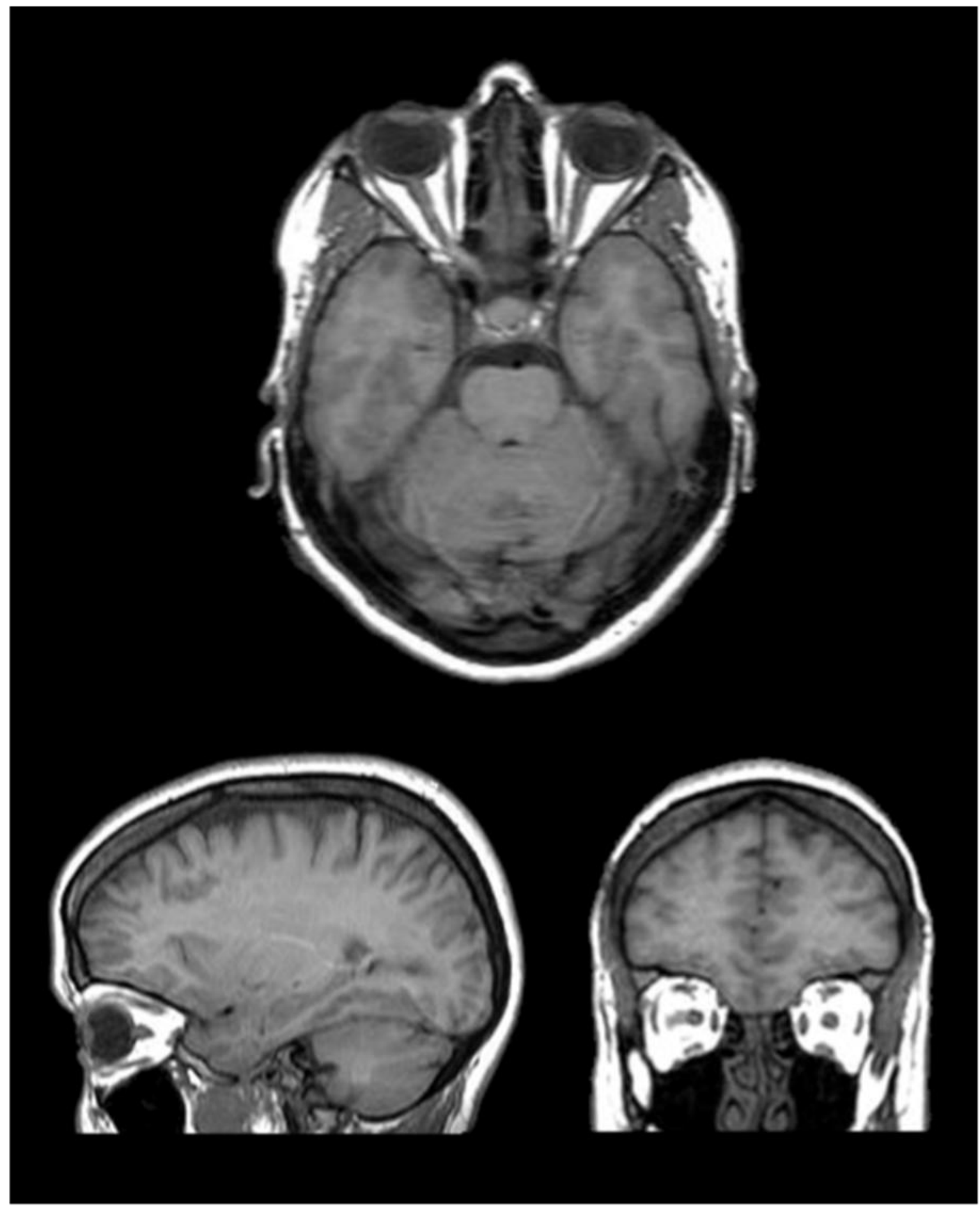

Figura 29.- Imágenes de RM de al to campo en las que se aprecia el nervio óptico en las tres incidencias (axial, sagital y coronal). 


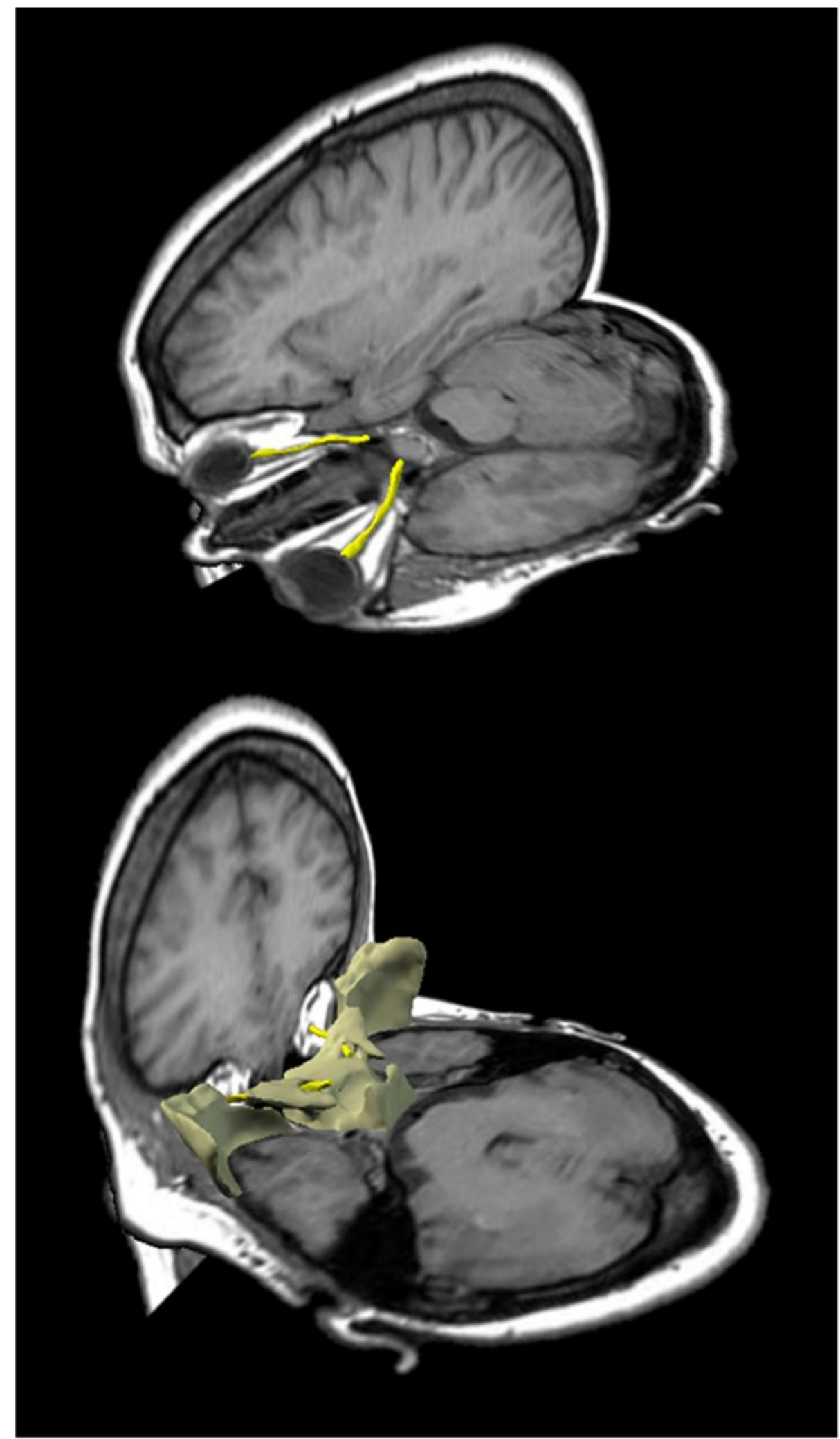

Figura 30.- Imágenes de Reconstrucción tridimensional del nervio óptico, embebido en secciones de RM, que muestra su paso a través del conducto óptico, antes de constituir el quiasma óptico. 

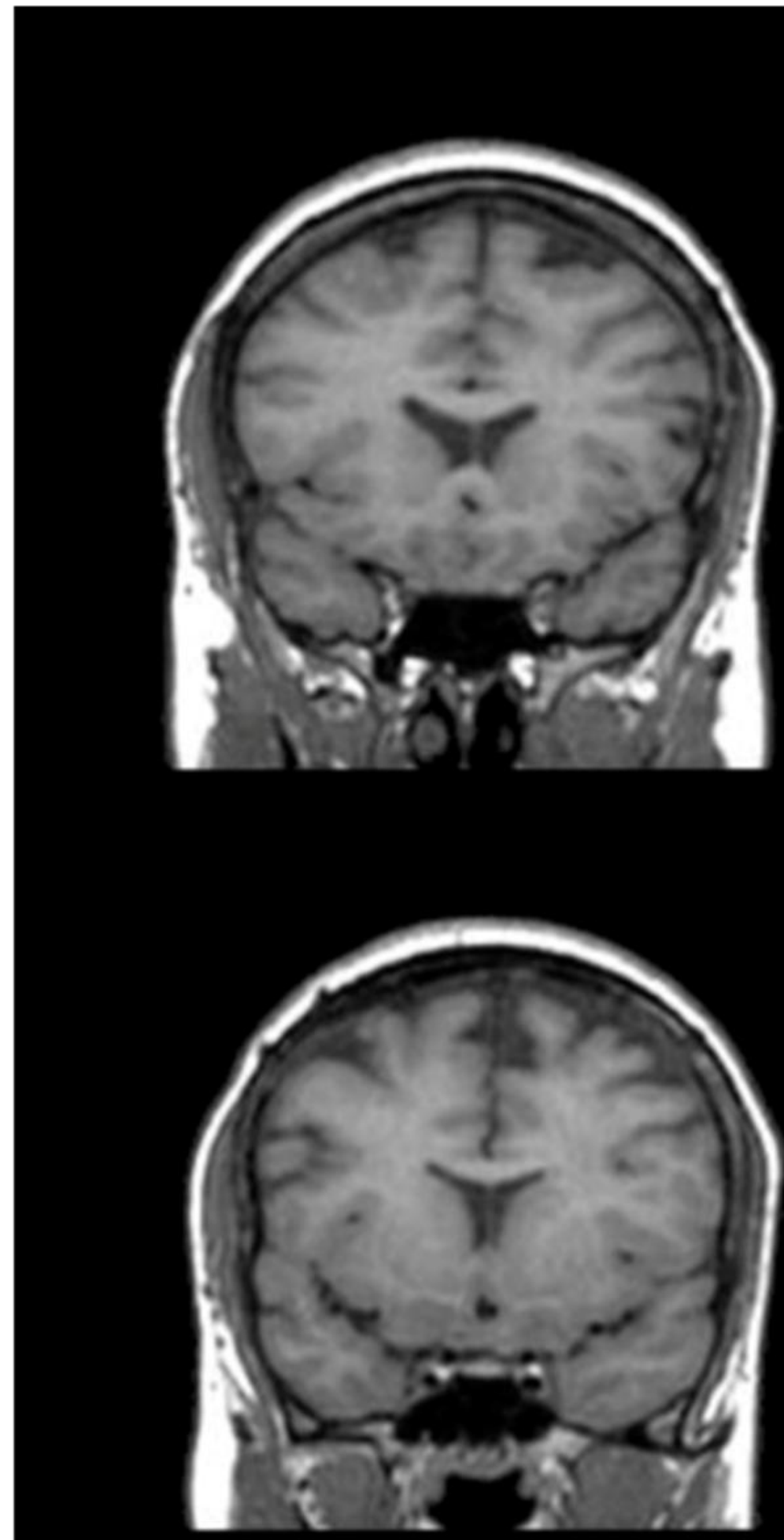

Figura 31.- Secciones coronales de Resonancia Magnética que muestran los nervios óp ticos en su entrada en la cavidad craneal (imagen superior) dispuesto lateralmente al seno esfenoidal y, una vez fusionados, formando el quiasma óptico (imagen inferior). 


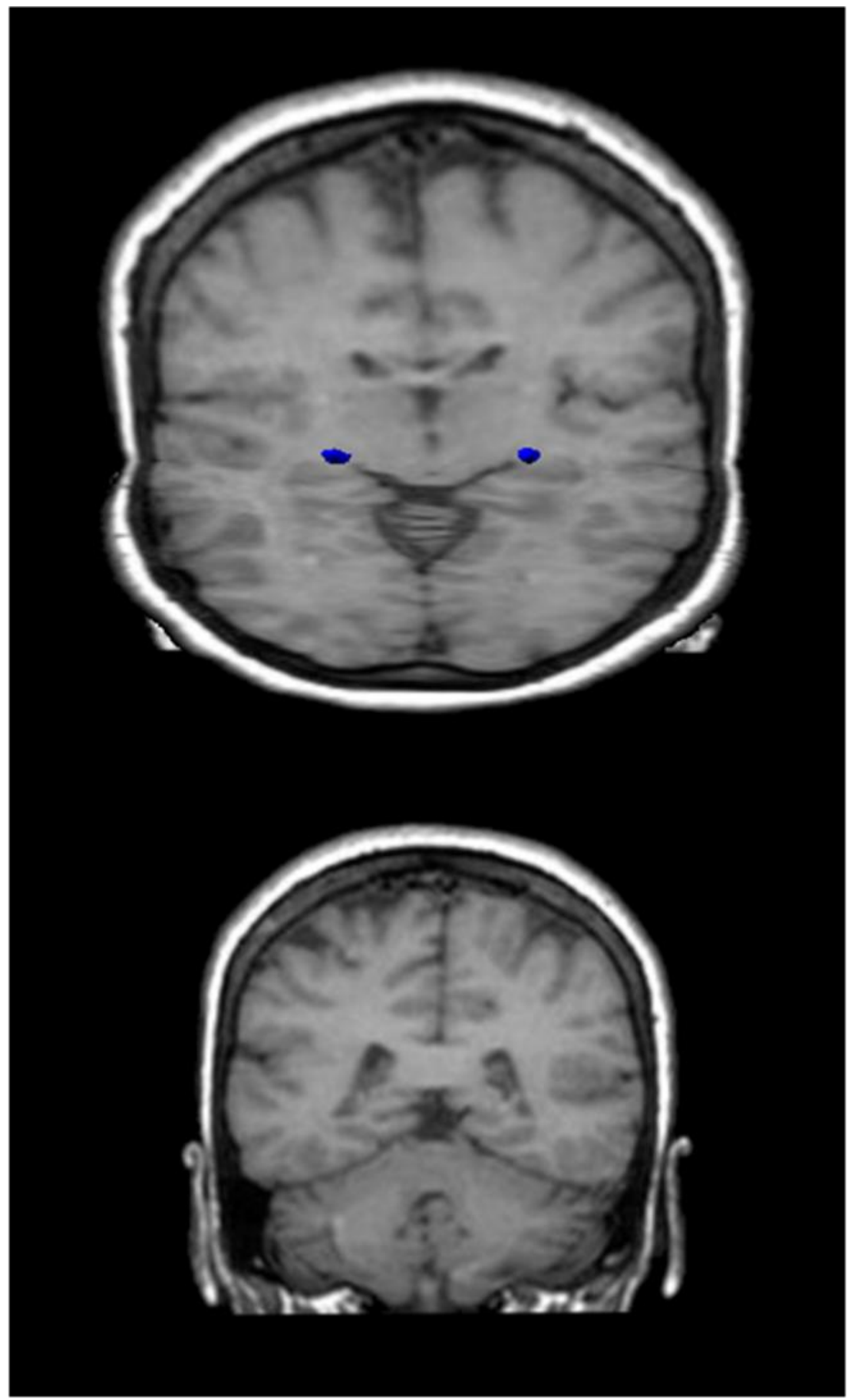

Figura 32.- Secciones coronales de Resonancia Magnética que muestran los cuerpos geniculados laterales reconstruidos en 3D (imagen superior) y las radiaciones ópticas y el tapetum bordeando lateralmente la prolongación occipital del ventrículo lateral (imagen inferior). 


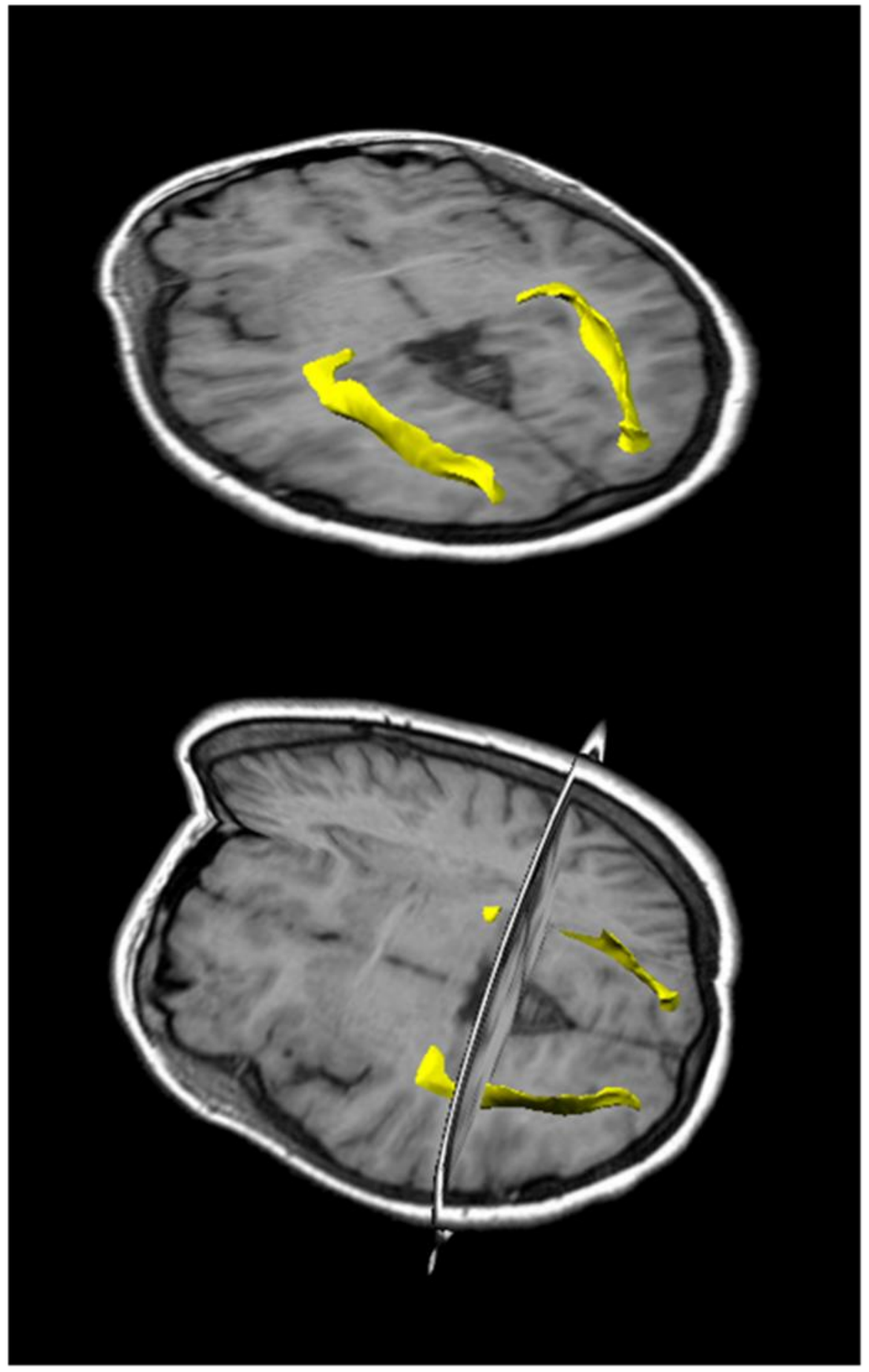

Figura 33.- Reconstrucciones 30 de la vía óptica, en las que se aprecian las radiaciones ópticas, incluida el asa de Meyer, y su llegada a la corteza occipital. 


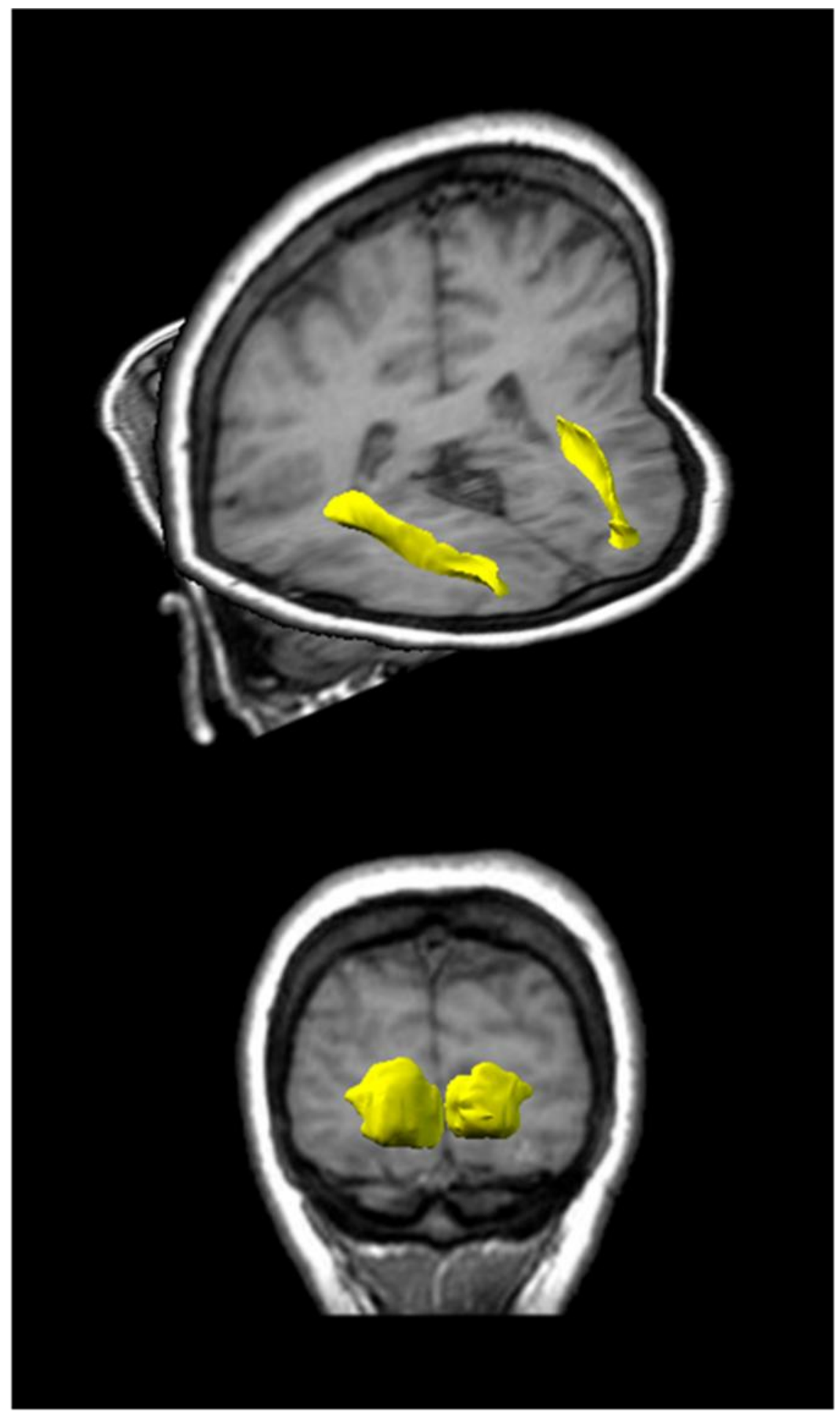

Figura 34.- Reconstrucciones 30 de la vía óptica, en las que se aprecian la distribución de las radiaciones ópticas por la corteza occipital, en torno a la cisura calcarina. 


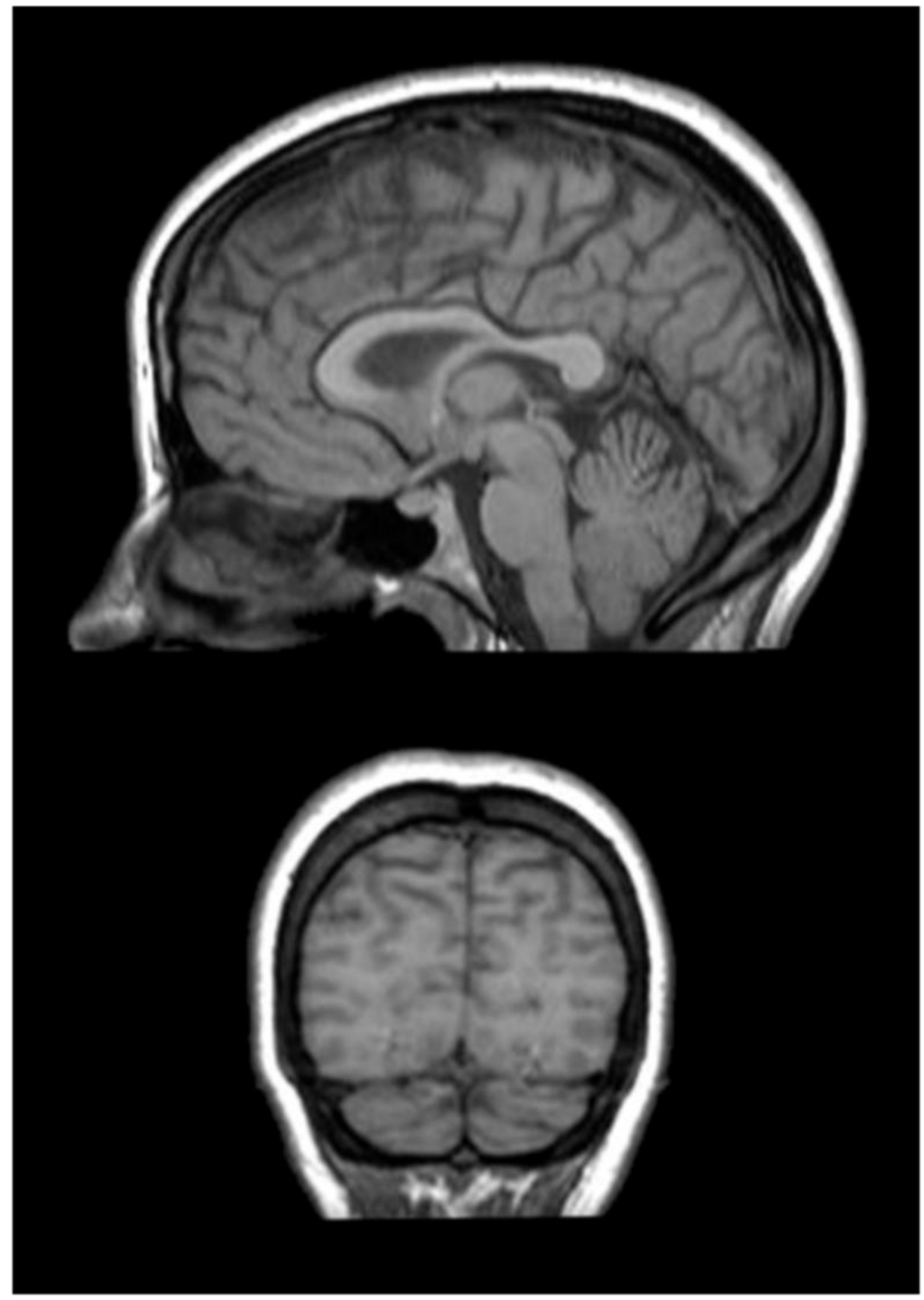

Figura 35.- Cortes sagital y coronal de Resonancia Magnética que muestran las áreas corticales 18 y 19 de Brodmann, situadas periféricamente con respecto al área 17 , centrada en la cisura calcarina. 


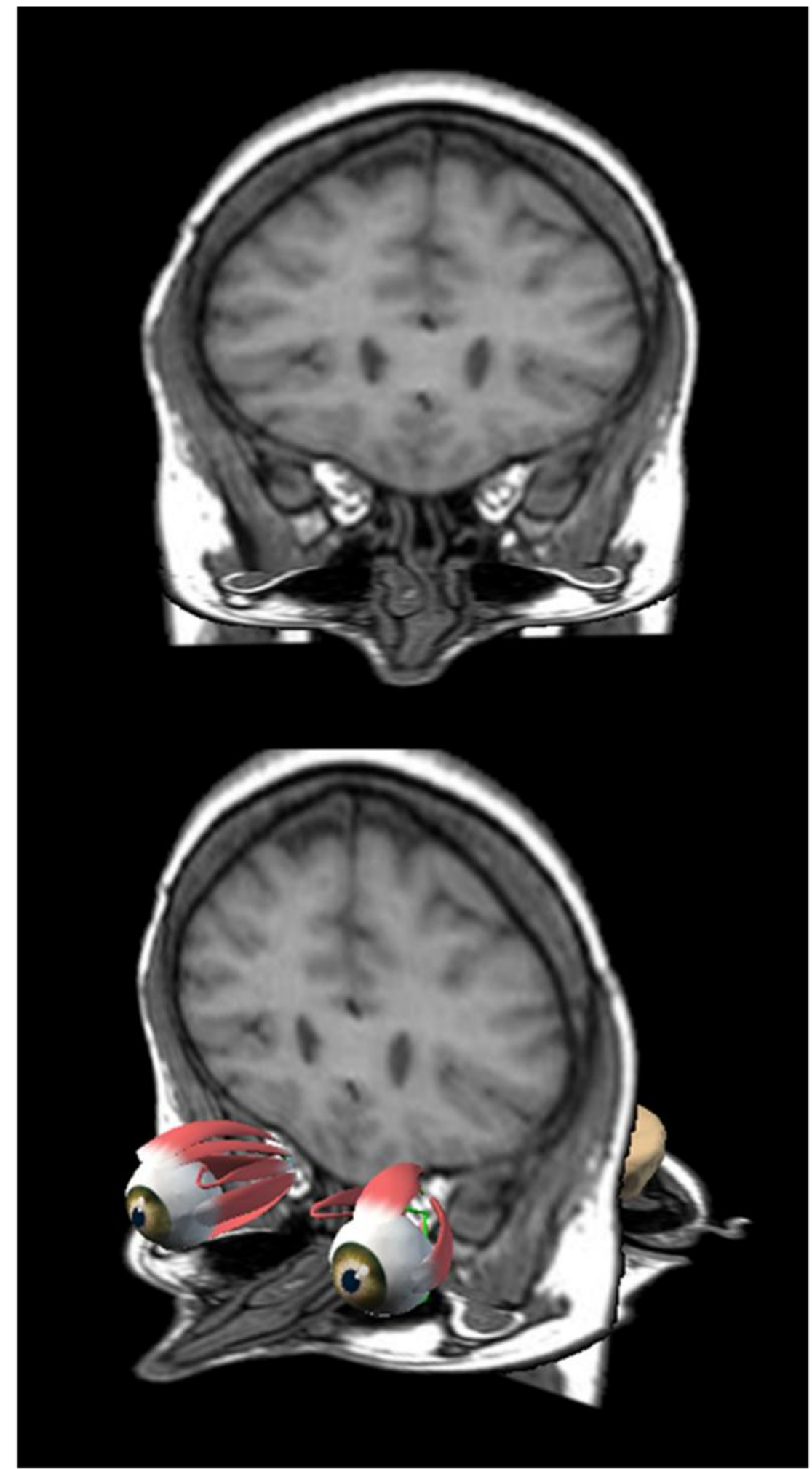

Figura 36.- Visualización de los músculos extraoculares en una sección coronal del fondo orbitario (imagen superior) y en una reconstrucción 3D, con el globo ocular embebido en secciones de resonancia magnética, en diferentes planos de corte (imagen inferior). 


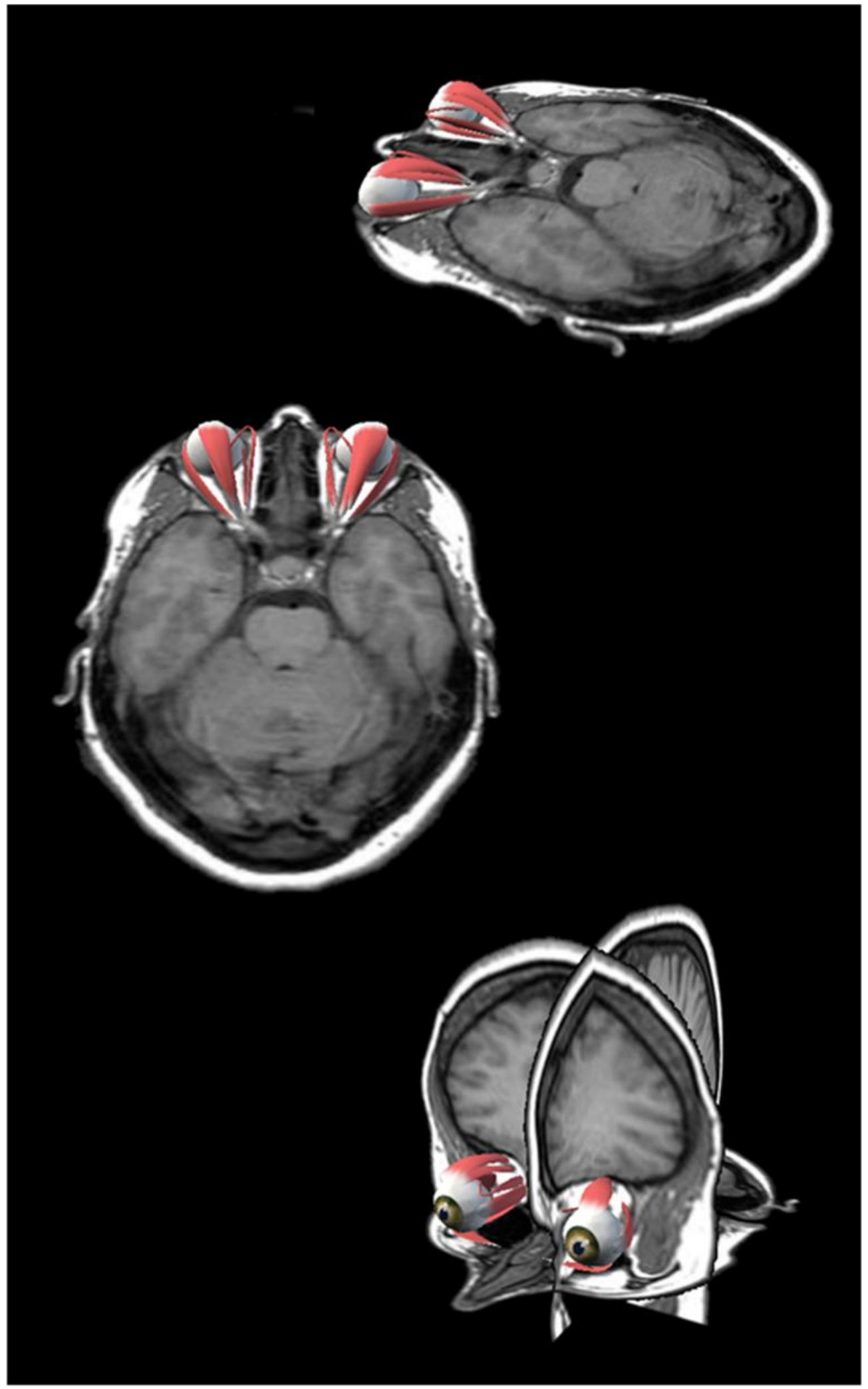

Figura 37.- Visualización tridimensional del conjunto de músculos extraoculares en diferentes rotaciones espaciales correlacionado con secciones planares de resonancia magnética. 


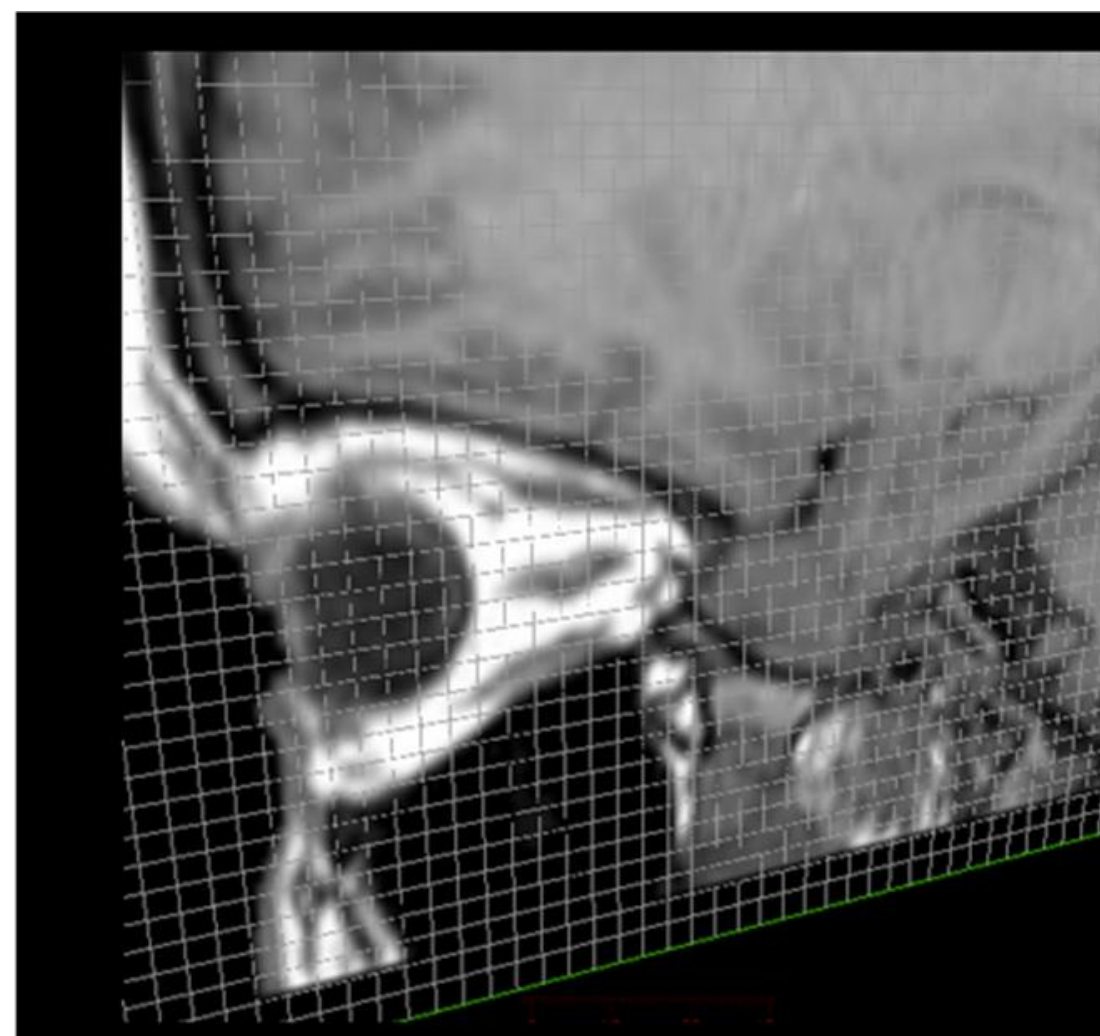

E
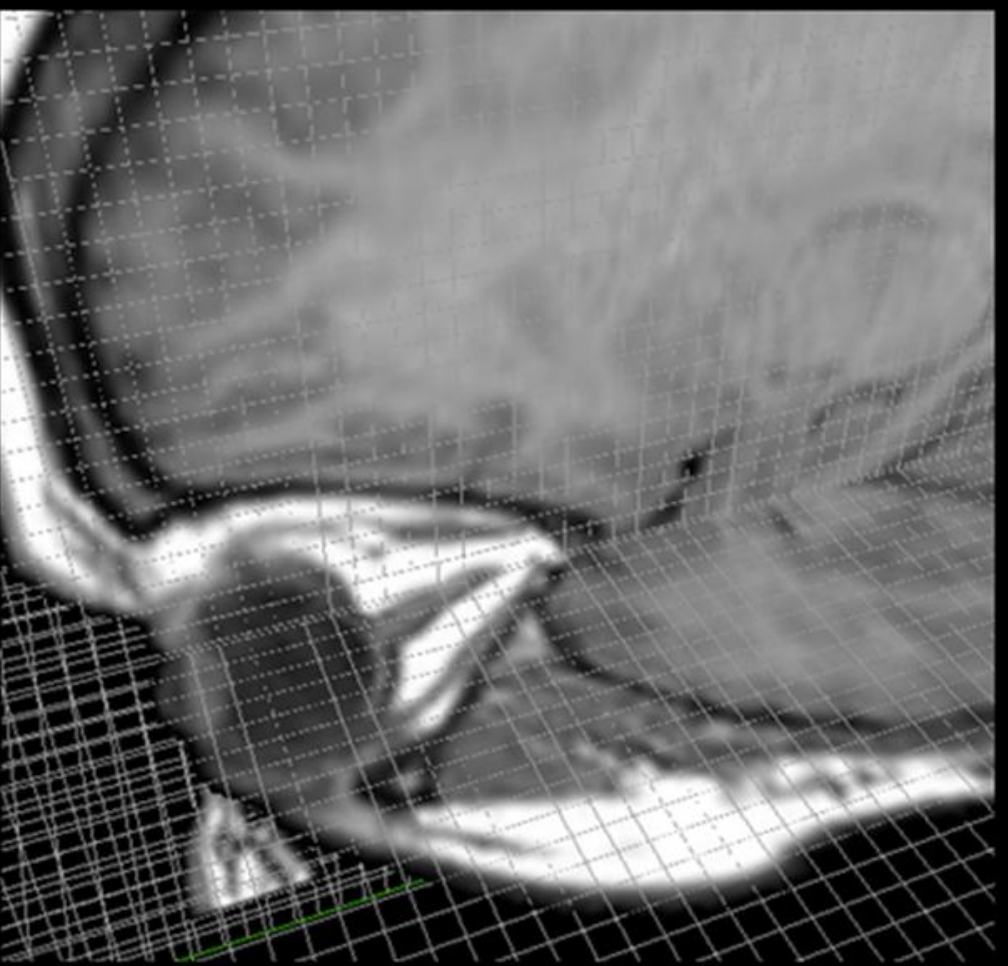

Figura 38.- Visualización tridimensional de resonancias magnéticas del globo ocular con malla superpuesta, constituida por cuadrícula de $3 \mathrm{~mm}$, para valorar distancias relacionadas con los músculos extraoculares. 


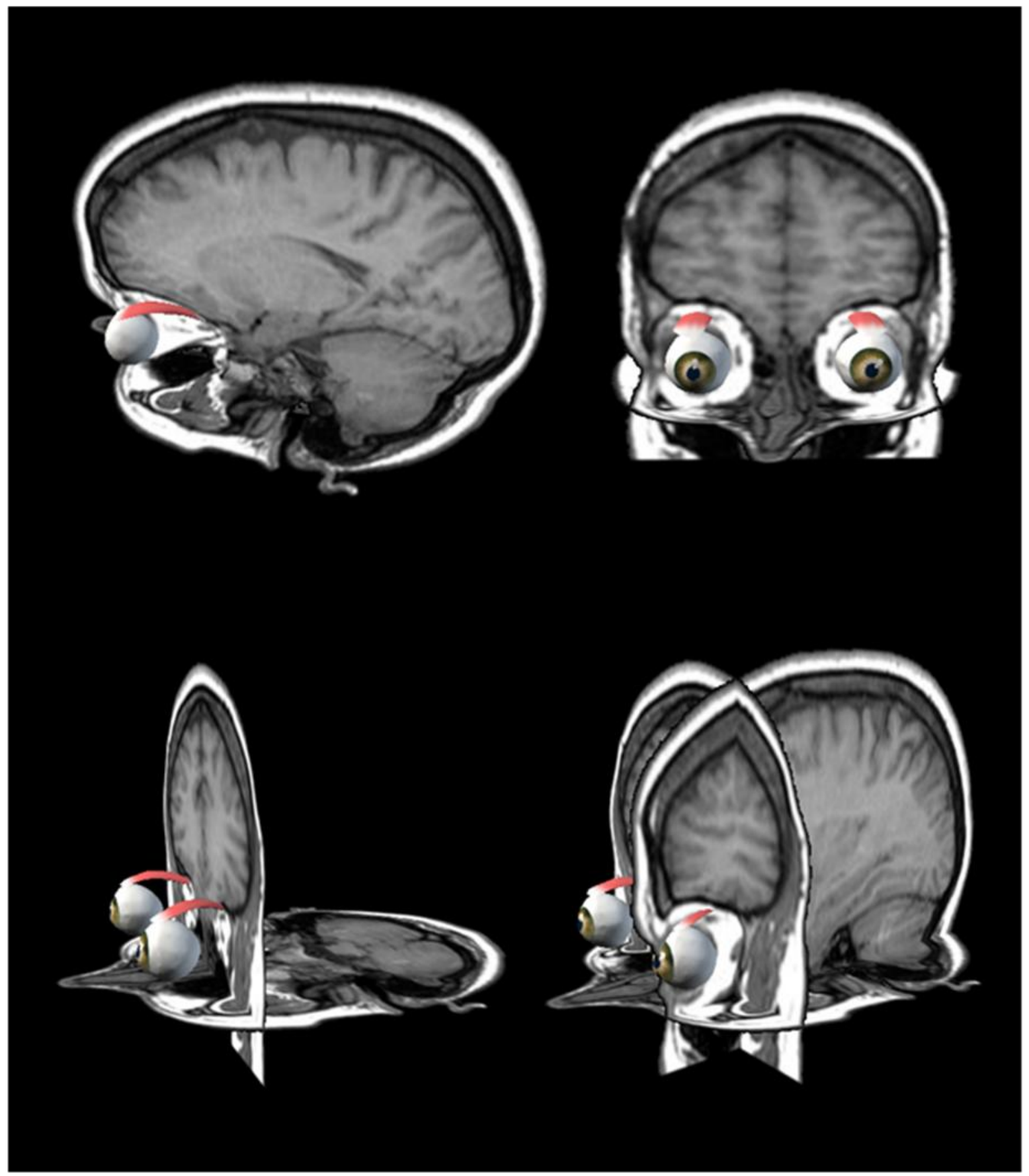

Figura 39.- Visualización tridimensional del músculo elevador de párpado superior en diferentes rotaciones espaciales correlacionado con secciones planares de resonancia magnética. 


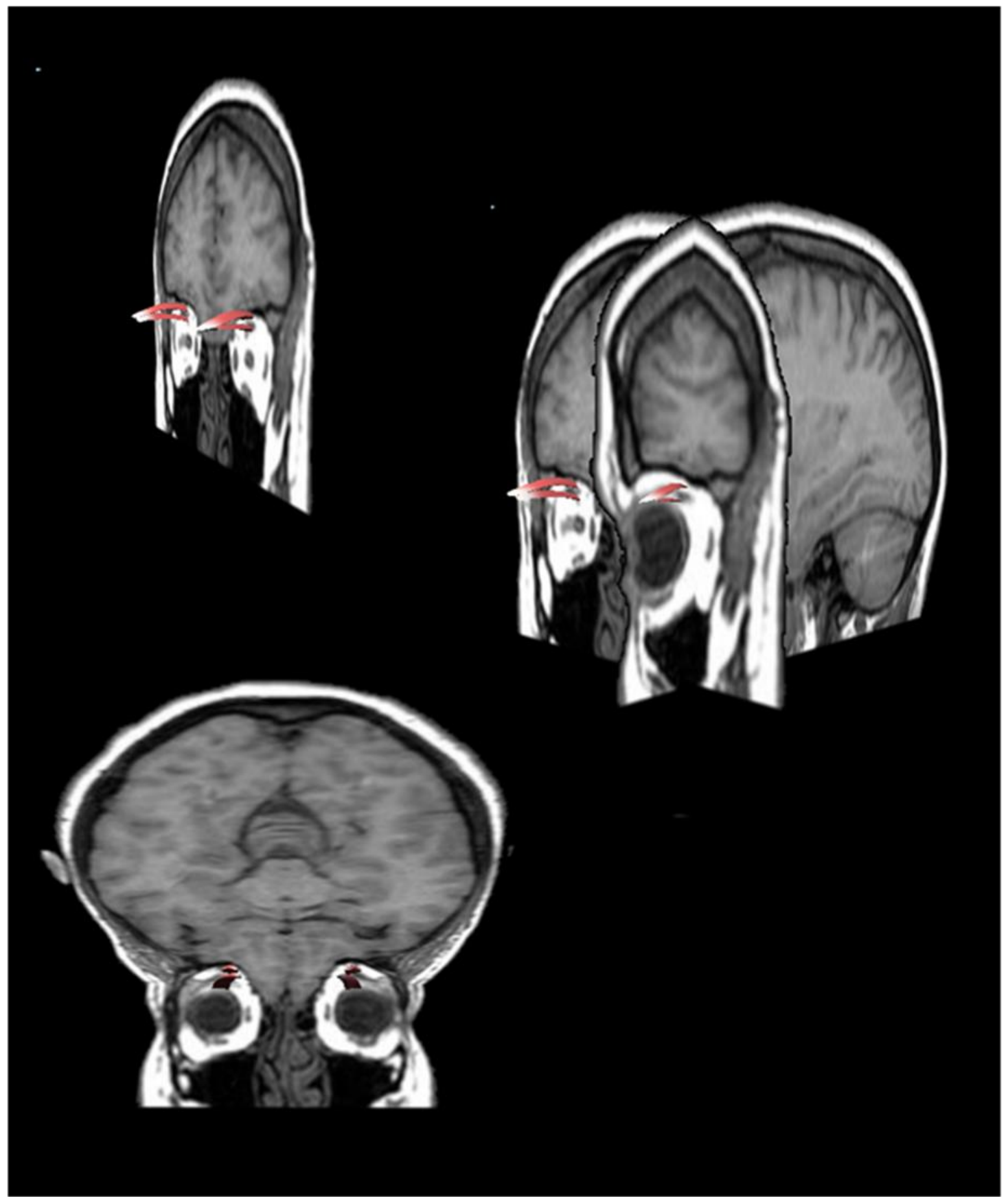

Figura 40.- Visualización tridimensional de los músculos elevador de párpado superior y recto superior, en diferentes rotaciones espaciales correlacionado con secciones planares de resonancia magnética. 


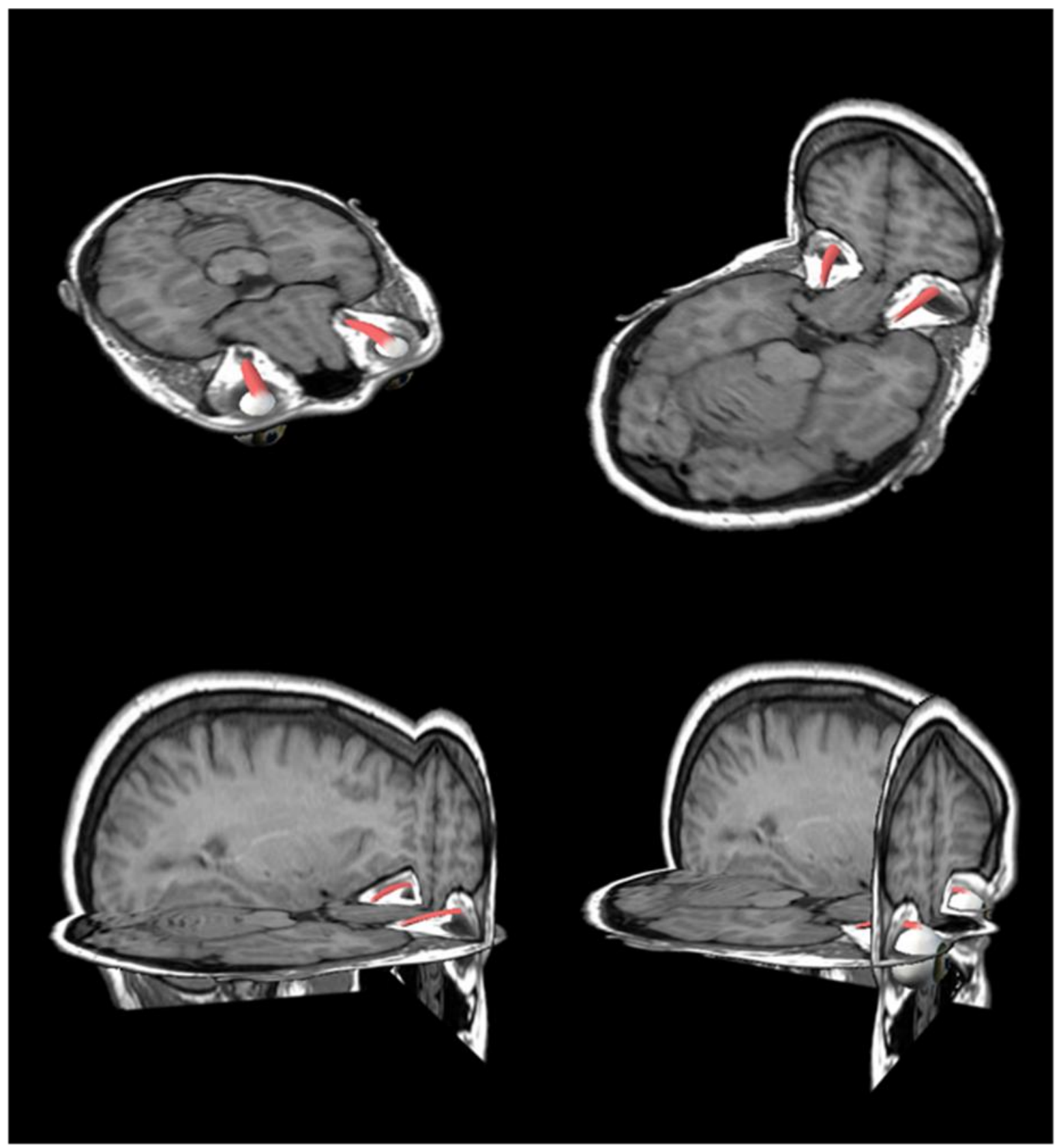

Figura 41.- Visualización tridimensional del músculo recto superior en diferentes rotaciones espaciales correlacionado con secciones planares de resonancia magnética. 


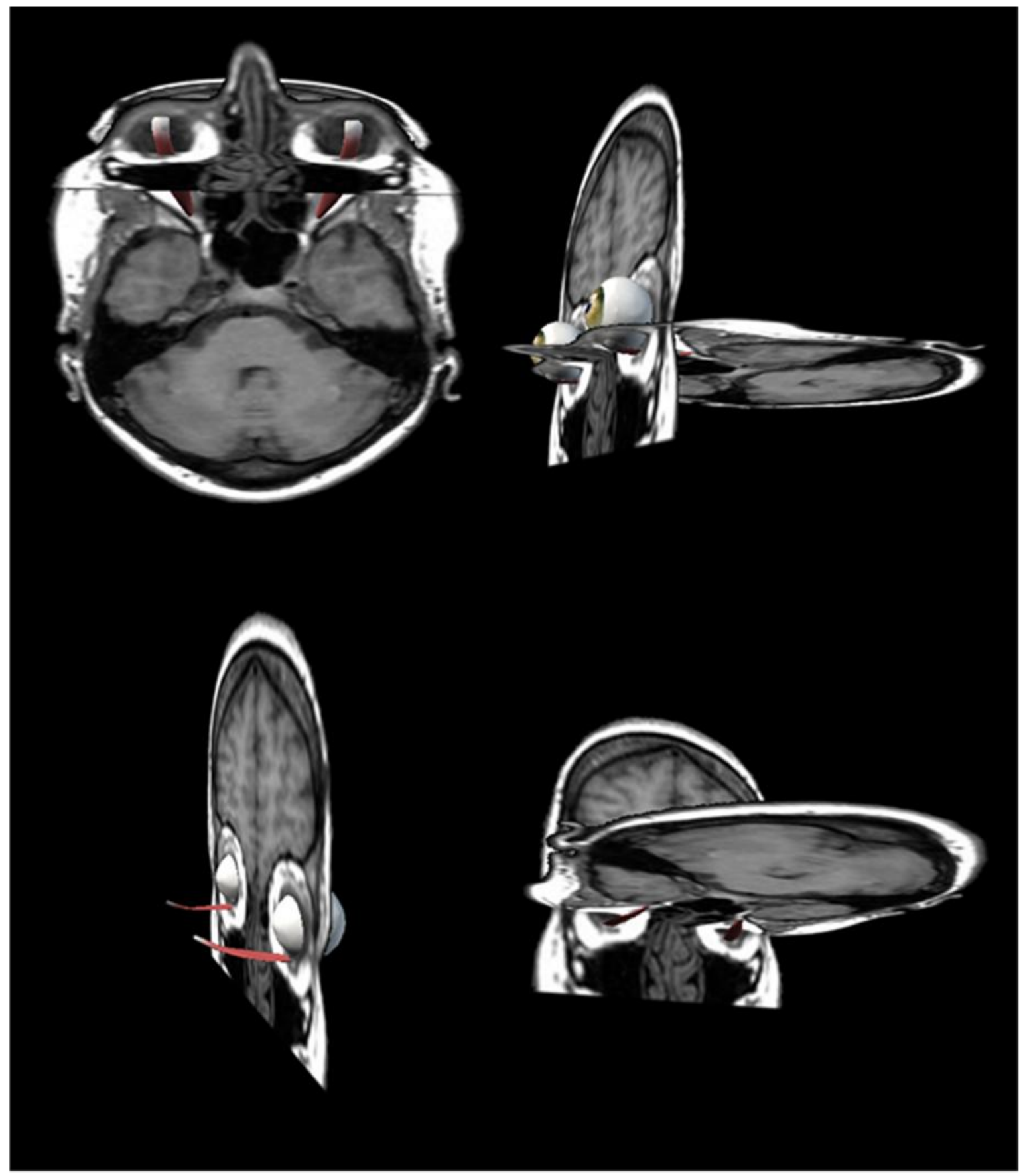

Figura 42.- Visualización tridimensional del músculo recto inferior en diferentes rotaciones espaciales correlacionado con secciones planares de resonancia magnética. 


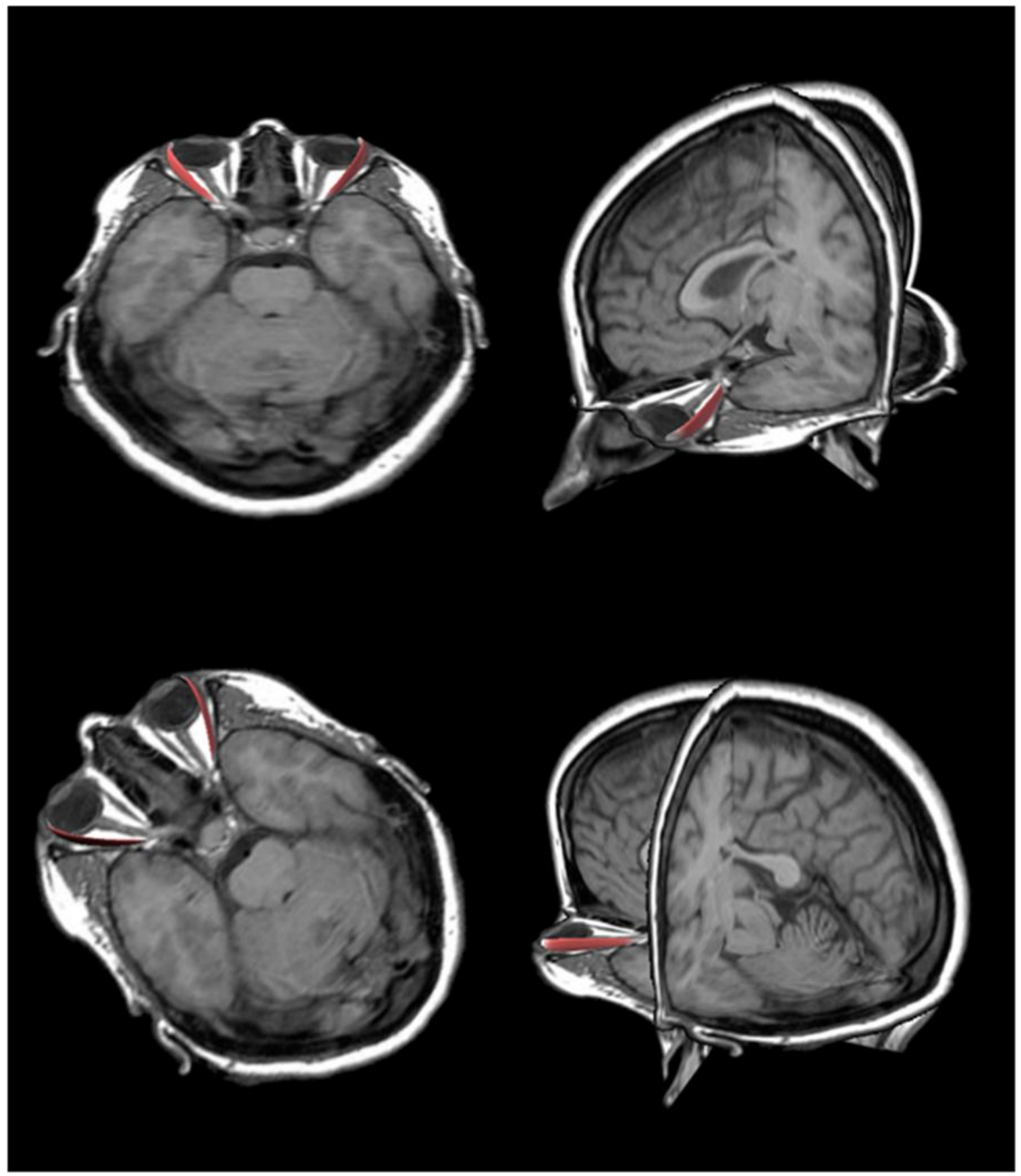

Figura 43.- Visualización tridimensional del músculo recto lateral en diferentes rotaciones espaciales correlacionado con secciones planares de resonancia magnética. 


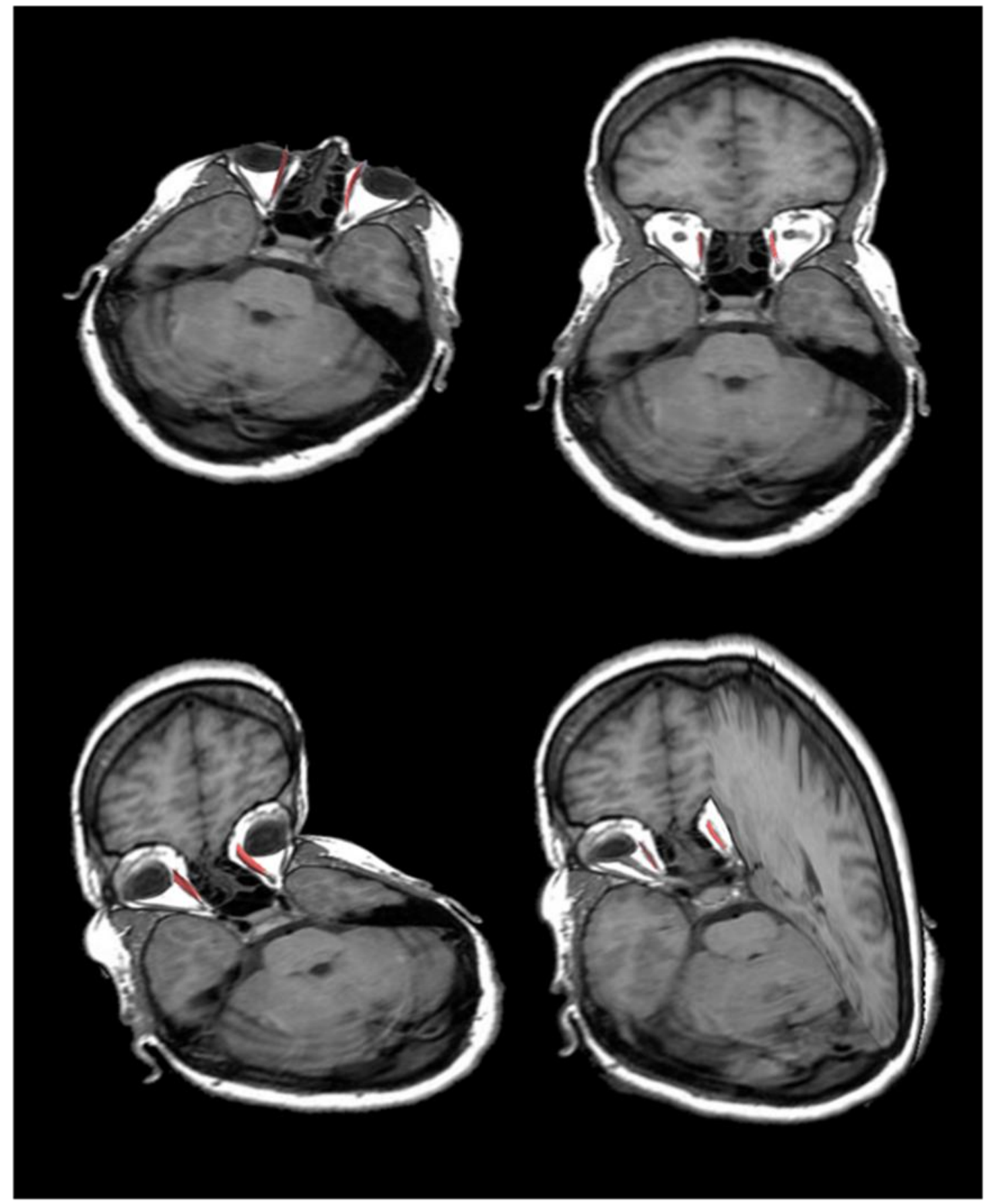

Figura 44.- Visualización tridimensional del músculo recto medial en diferentes rotaciones espaciales correlacionado con secciones planares de resonancia magnética. 


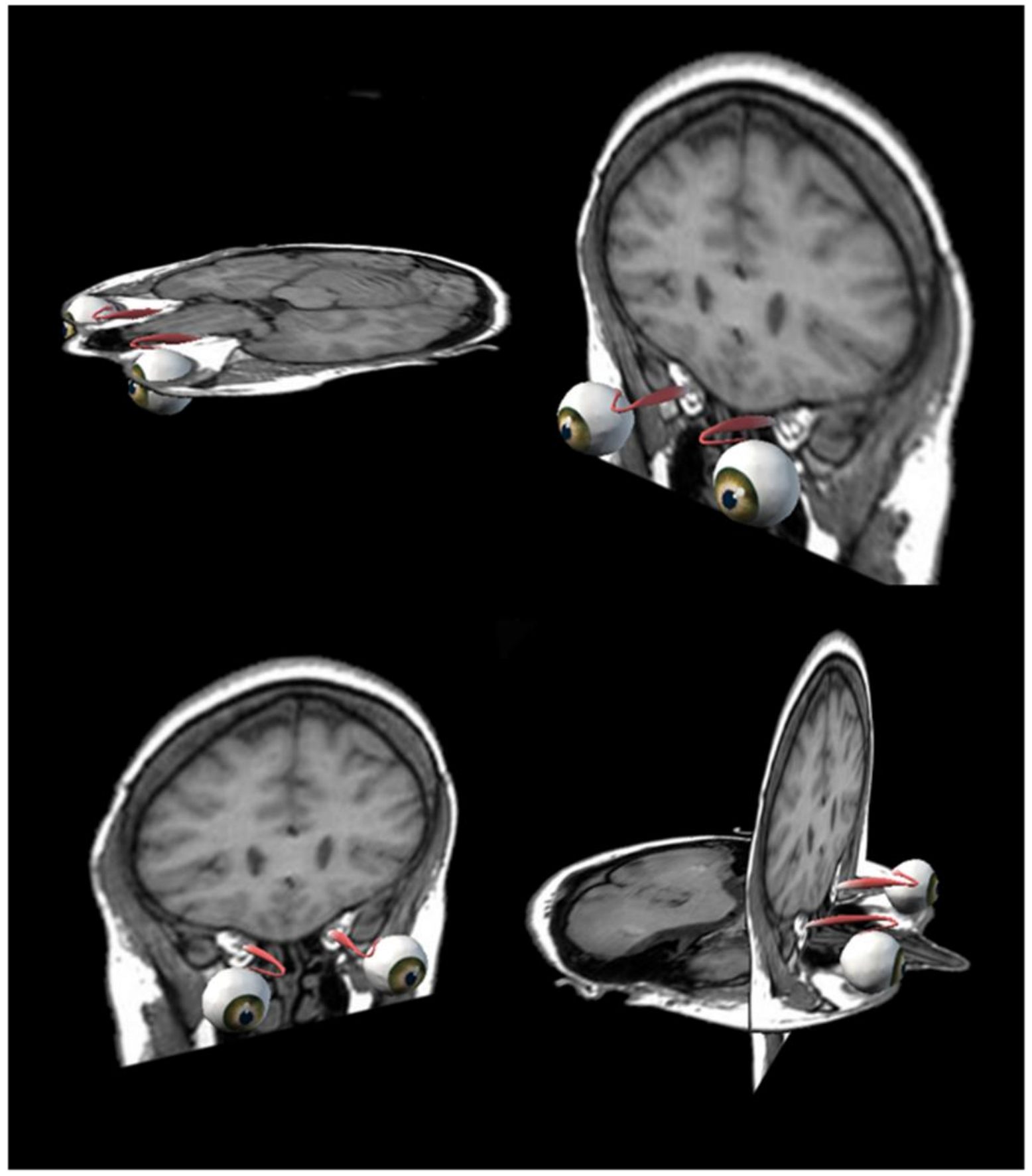

Figura 45.- Visualización tridimensional del músculo oblicuo superior en diferentes rotaciones espaciales correlacionado con secciones planares de resonancia magnética. 


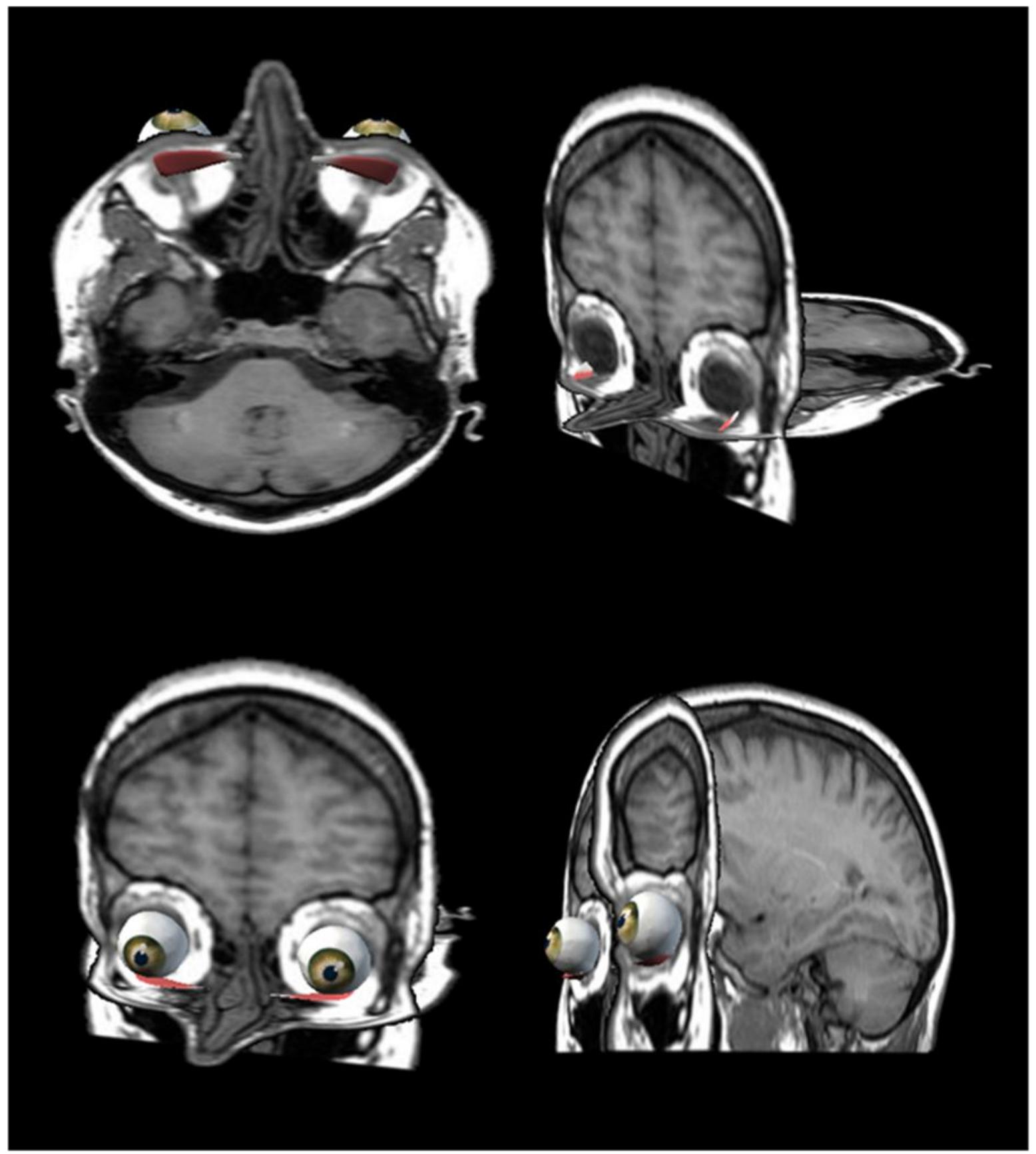

Figura 46.- Visualización tridimensional del músculo oblicuo inferior en diferentes rotaciones espaciales correlacionado con secciones planares de resonancia magnética. 


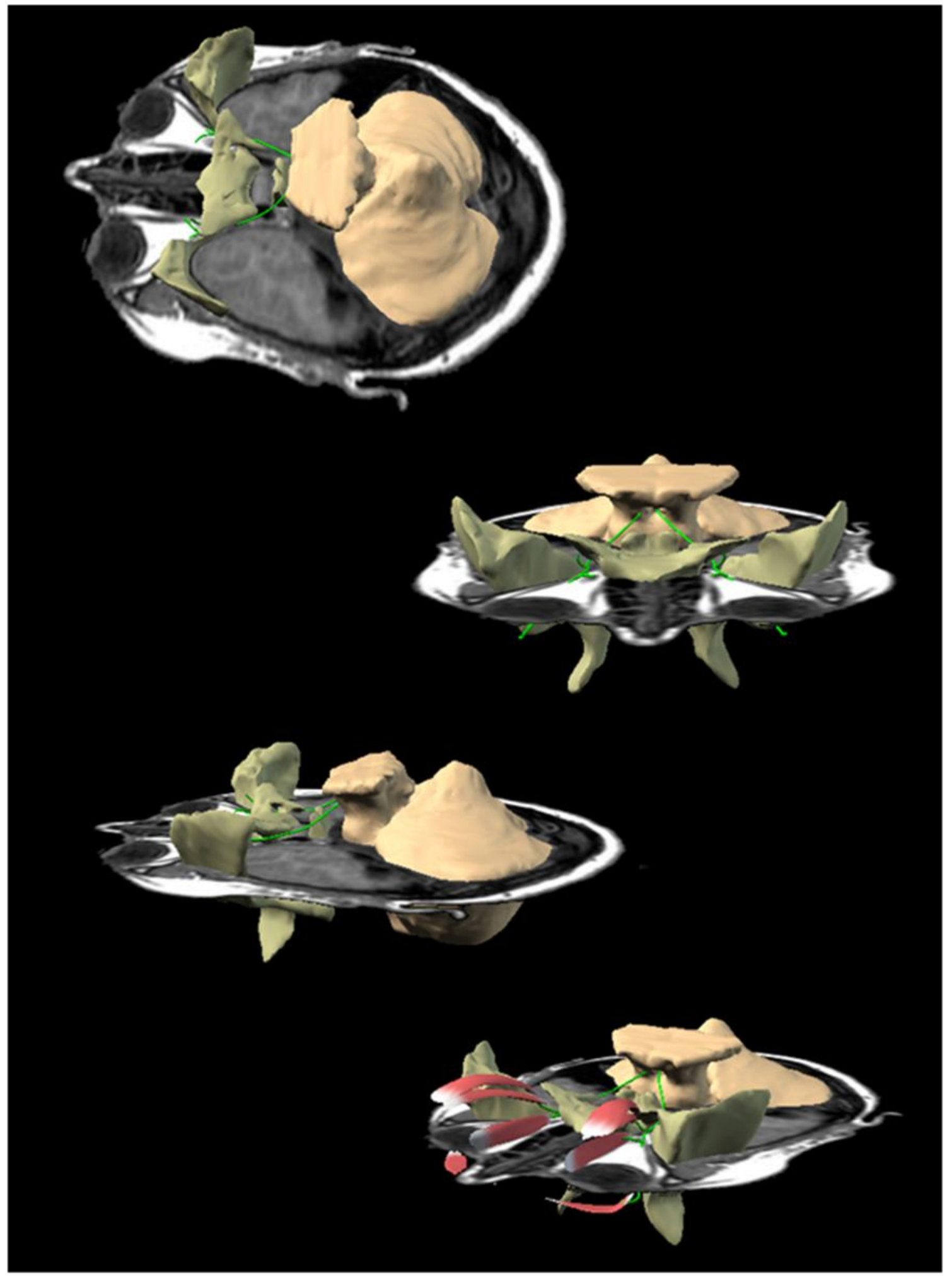

Figura 47.- Visualización tridimensional del III par craneal (nervio motor ocular común), desde su origen hasta su destino, junto con los músculos inervados por el par craneal, en diferentes rotaciones espaciales correlacionado con secciones planares de resonancia magnética. 

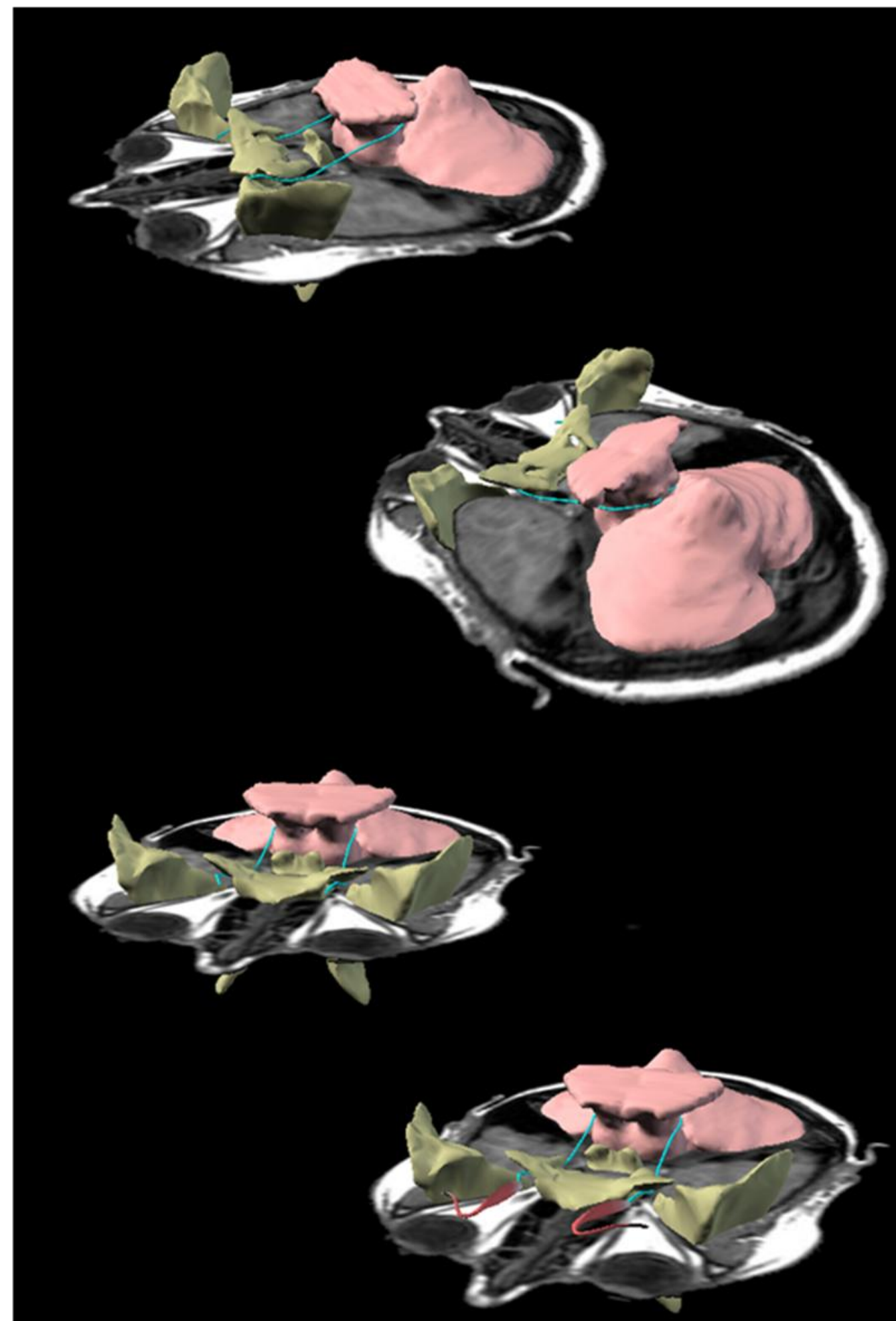

Figura 48.- Visualización tridimensional del IV par craneal (nervio patético o troclear), desde su origen hasta su destino, inervando al músculo oblicuo superior, en diferentes rotaciones espaciales correlacionado con secciones planares de resonancia magnética. 


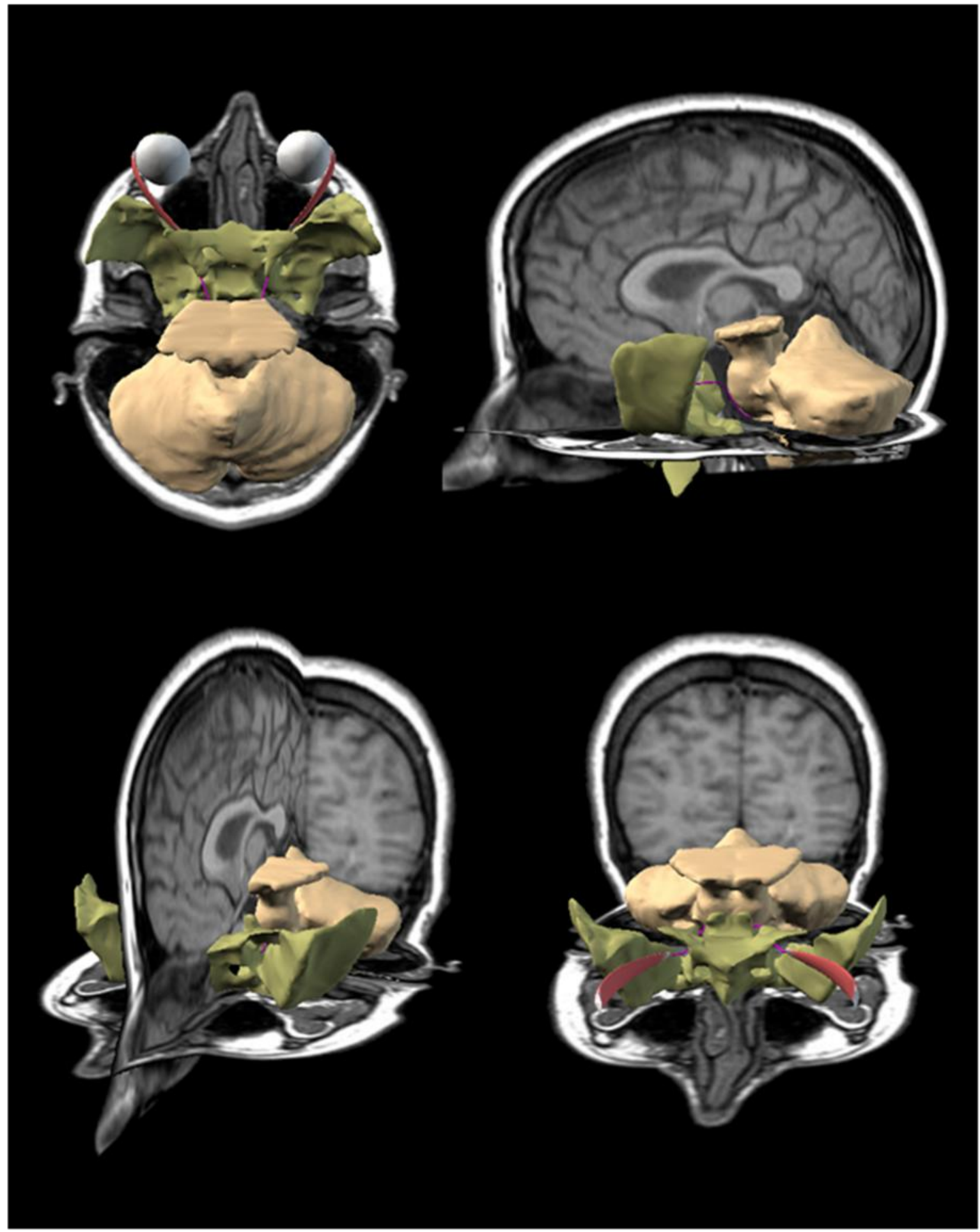

Figura 49.- Visualización tridimensional del VI par craneal (nervio abducens o motor ocular externo), desde su origen hasta su destino, inervando al músculo recto lateral, en diferentes rotaciones espaciales correlacionado con secciones planares de resonancia magnética. 


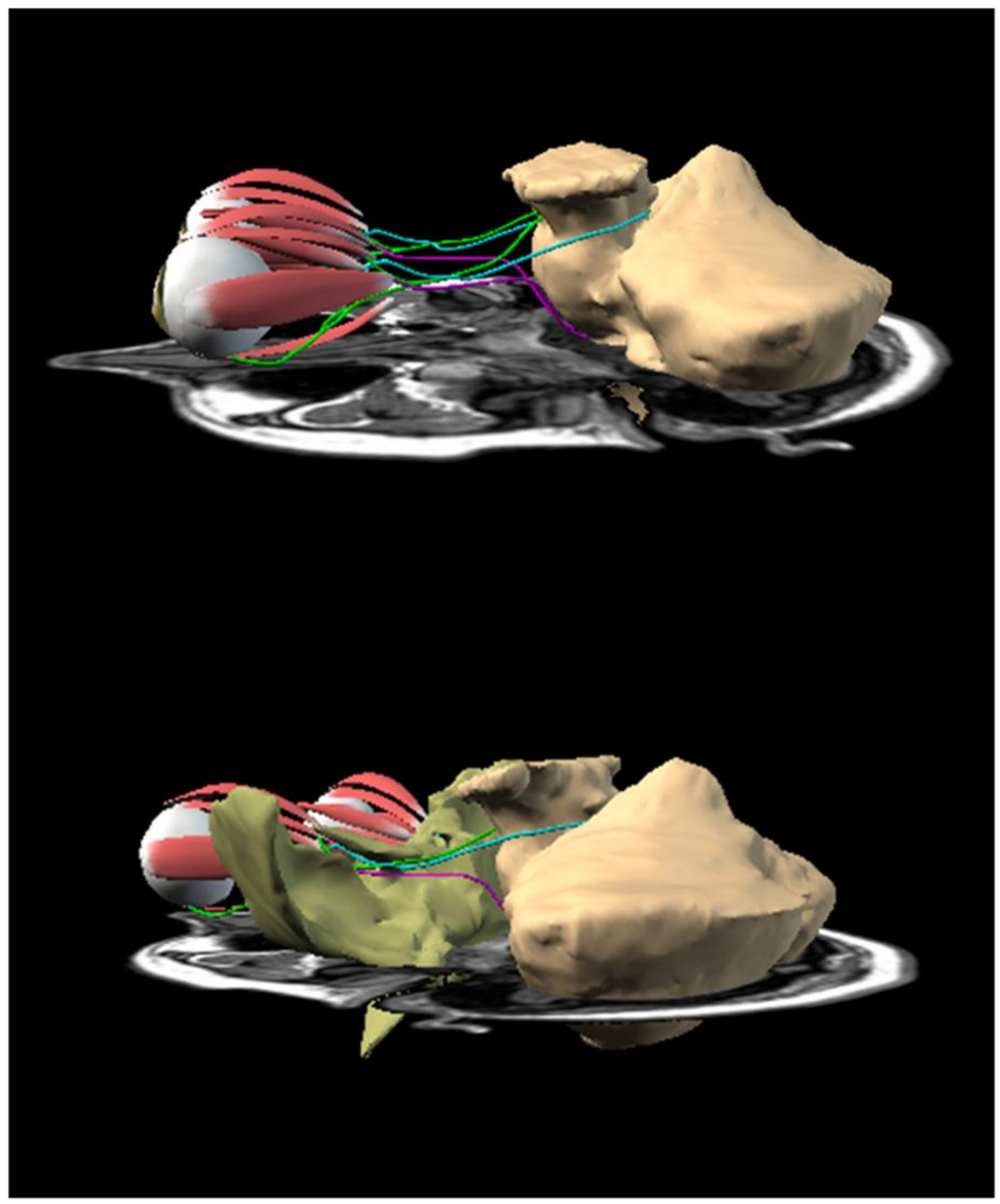

Figura 50.- Visualización tridimensional de los tres pares craneales (III, en verde; IV, en azul, y VI par, en morado), con sus trayectos y relaciones mutuas, desde su origen hasta su destino y los músculos por ellos inervados, en diferentes rotaciones espaciales correlacionado con secciones planares de resonancia magnética. 


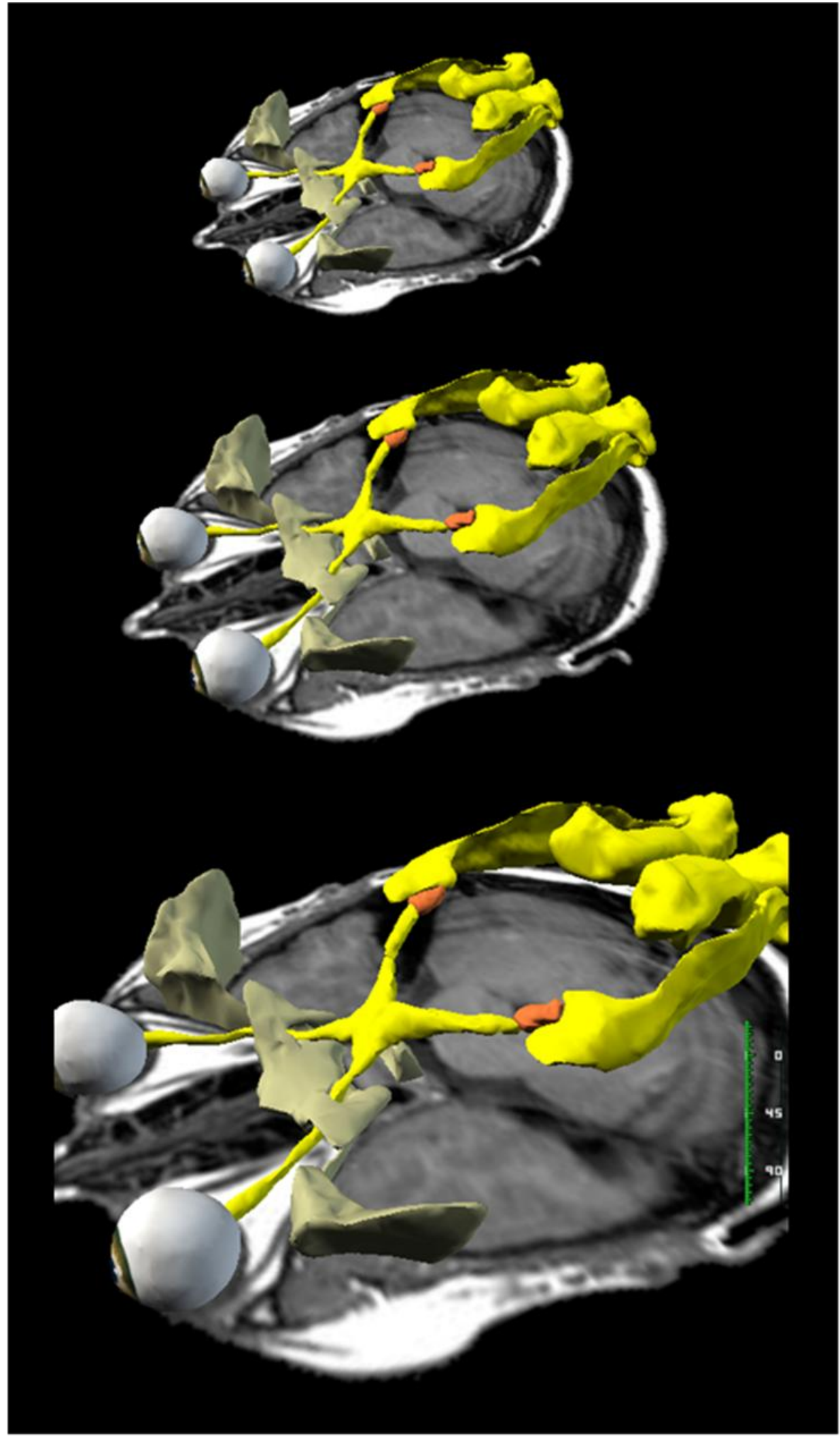

Figura 51.- Zoom de la vía óptica que se consigue a través del desarrollo informático. 


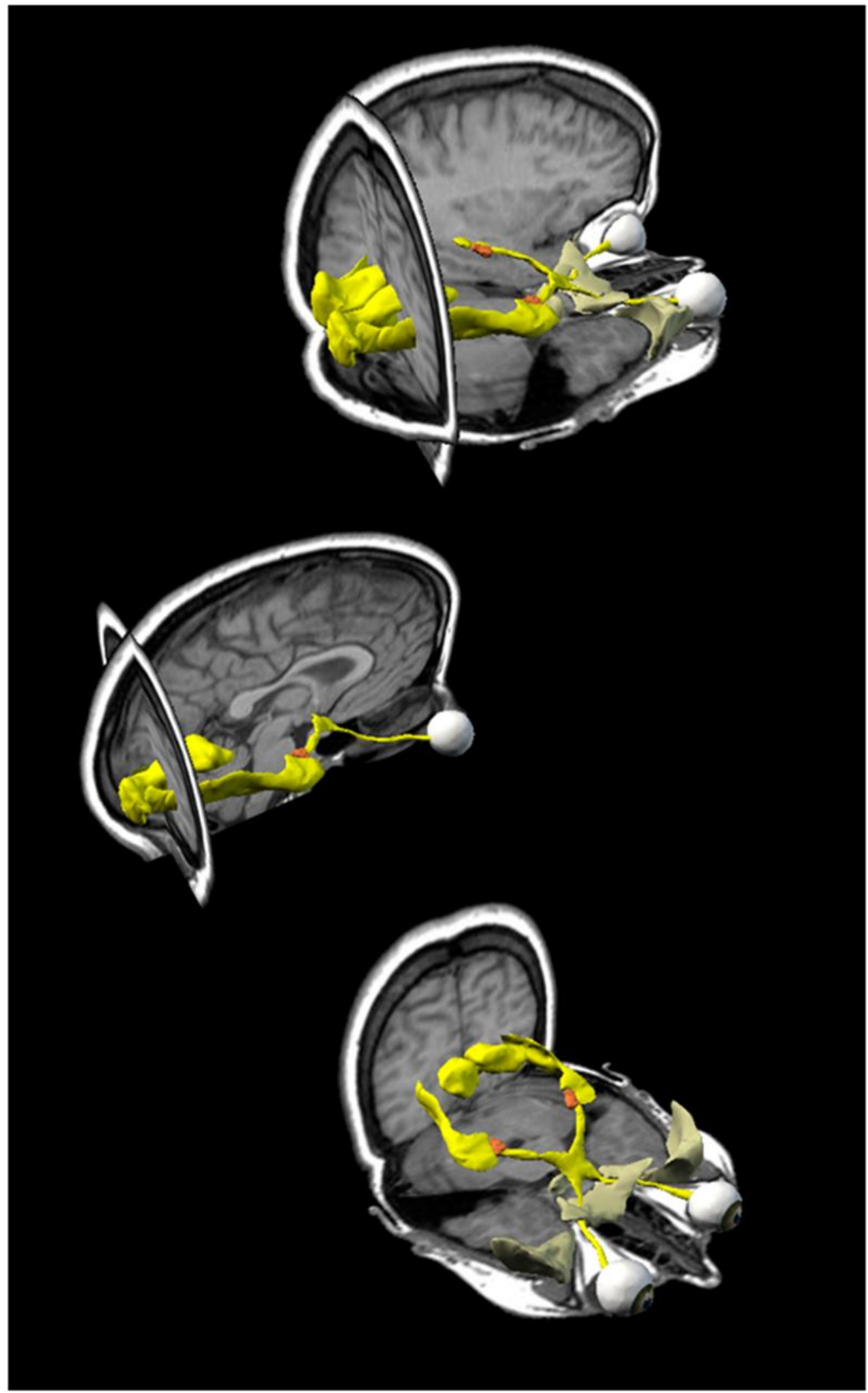

Figura 52.- Representación 3D de la vía óptica en conjunto, embebida en imágenes de $\mathrm{RM}$ en diferentes planos espaciales. 


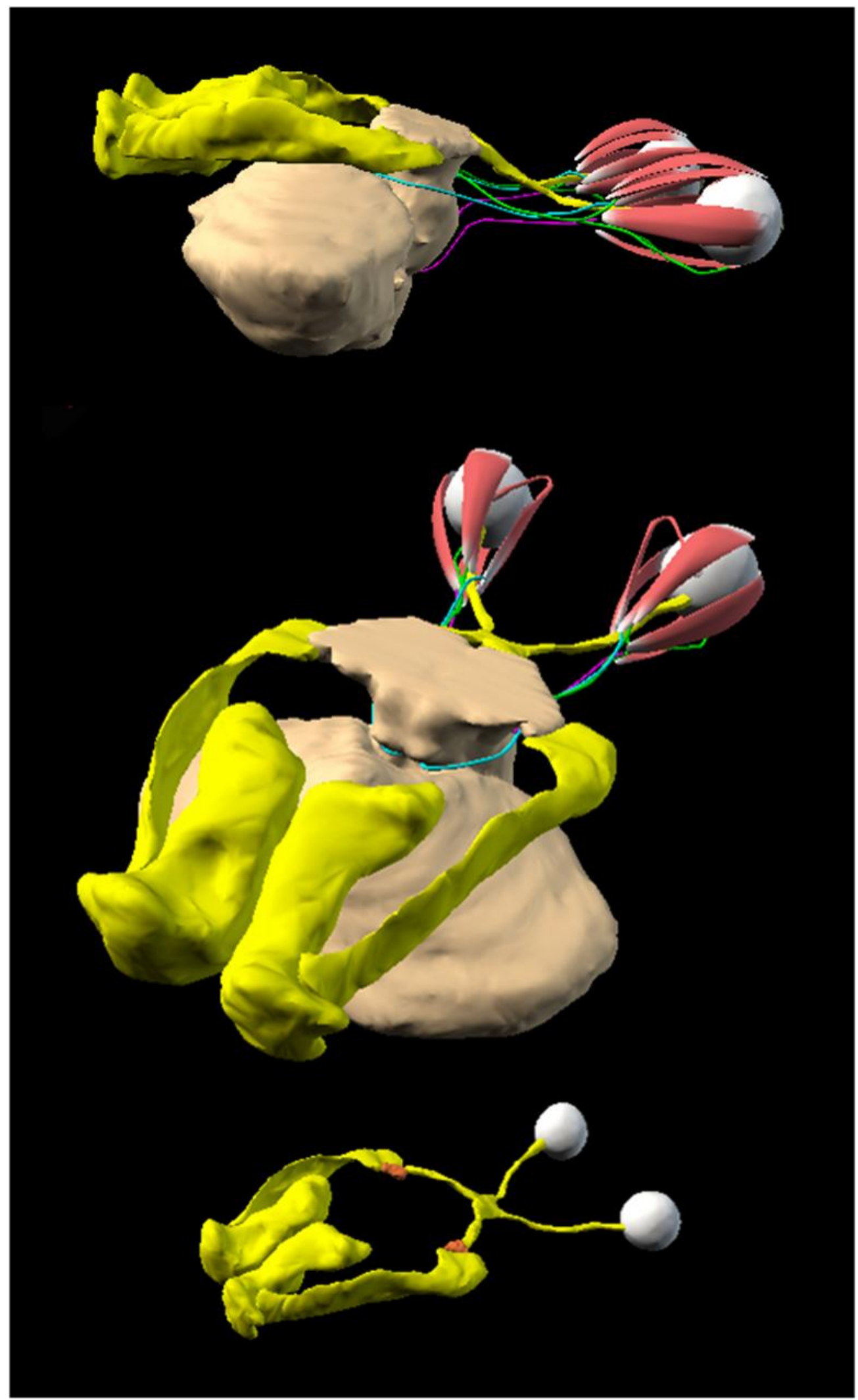

Figura 53.- Imágenes en diferentes posiciones espaciales que ilustran, en conjunto, la vía óptica y el aparato oculomotor con los nervios correspondientes (III, IV y VI par). 


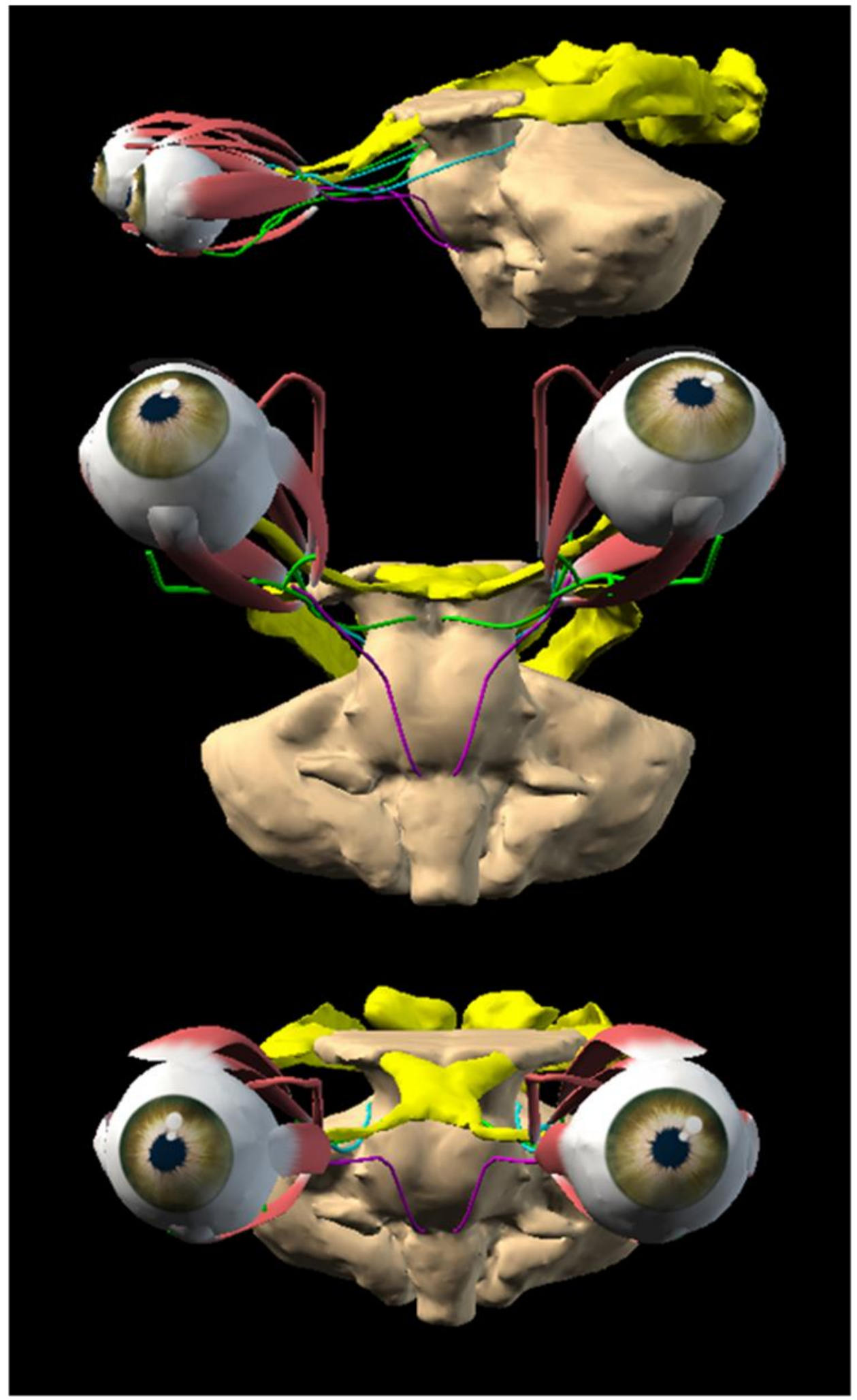

Figura 54.- Visualización 3D del origen aparente y trayecto de los nervios craneales: III (verde) surgiendo por el espacio interpeduncular; IV (azul), partiendo desde la lámina cuadrigémina mesencefálica y contorneando los pedúnculos cerebrales para dirigirse al seno cavernoso; VI (magenta) saliendo por el surco bulbo pontino. 


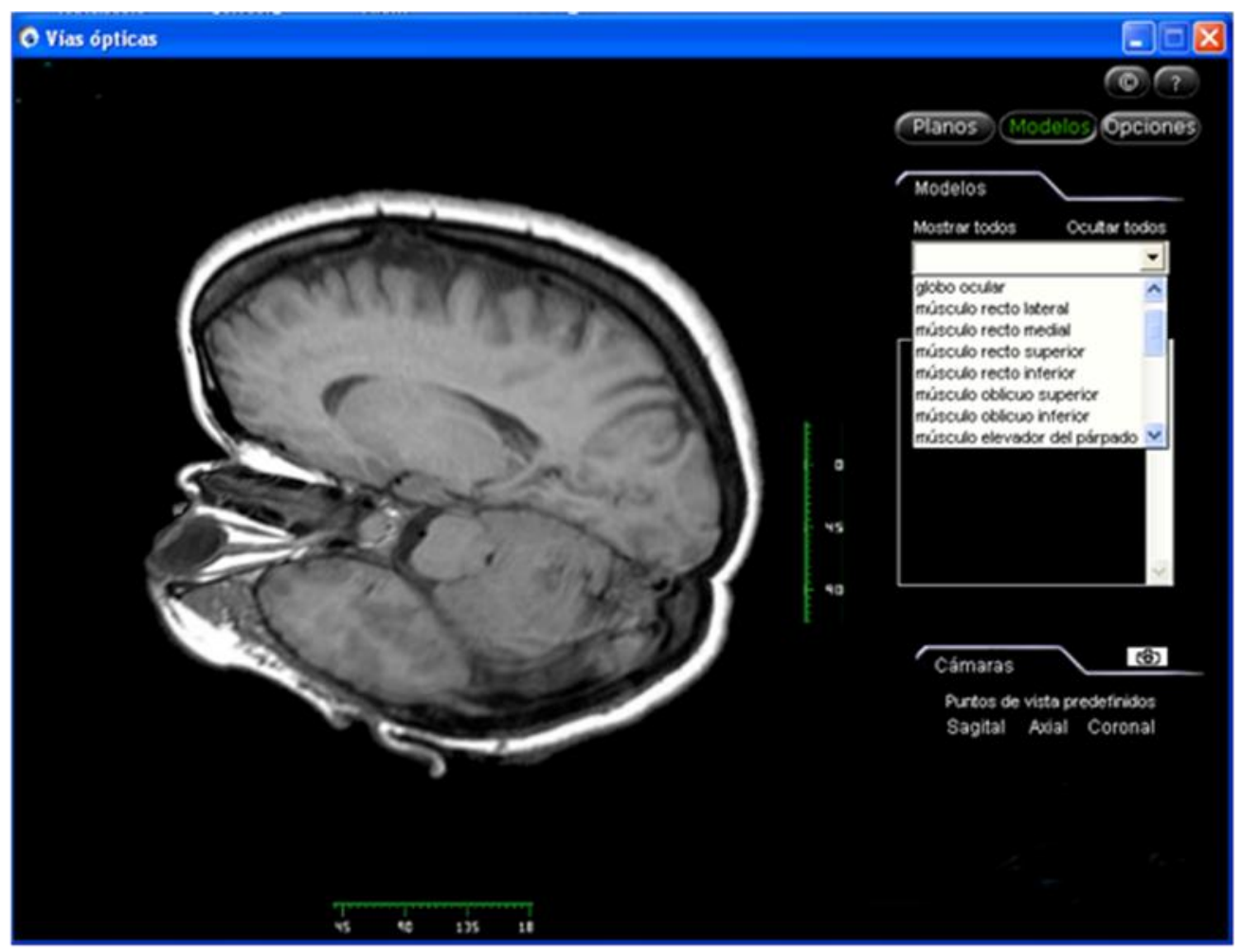

Figura 55.- Interface de usuario de la aplicación informática, en la que se aprecia las distintas opciones de elementos visuales: Planos y Modelos. Las estructuras 3D, se localizan en el menú desplegable, alfabéticamente.

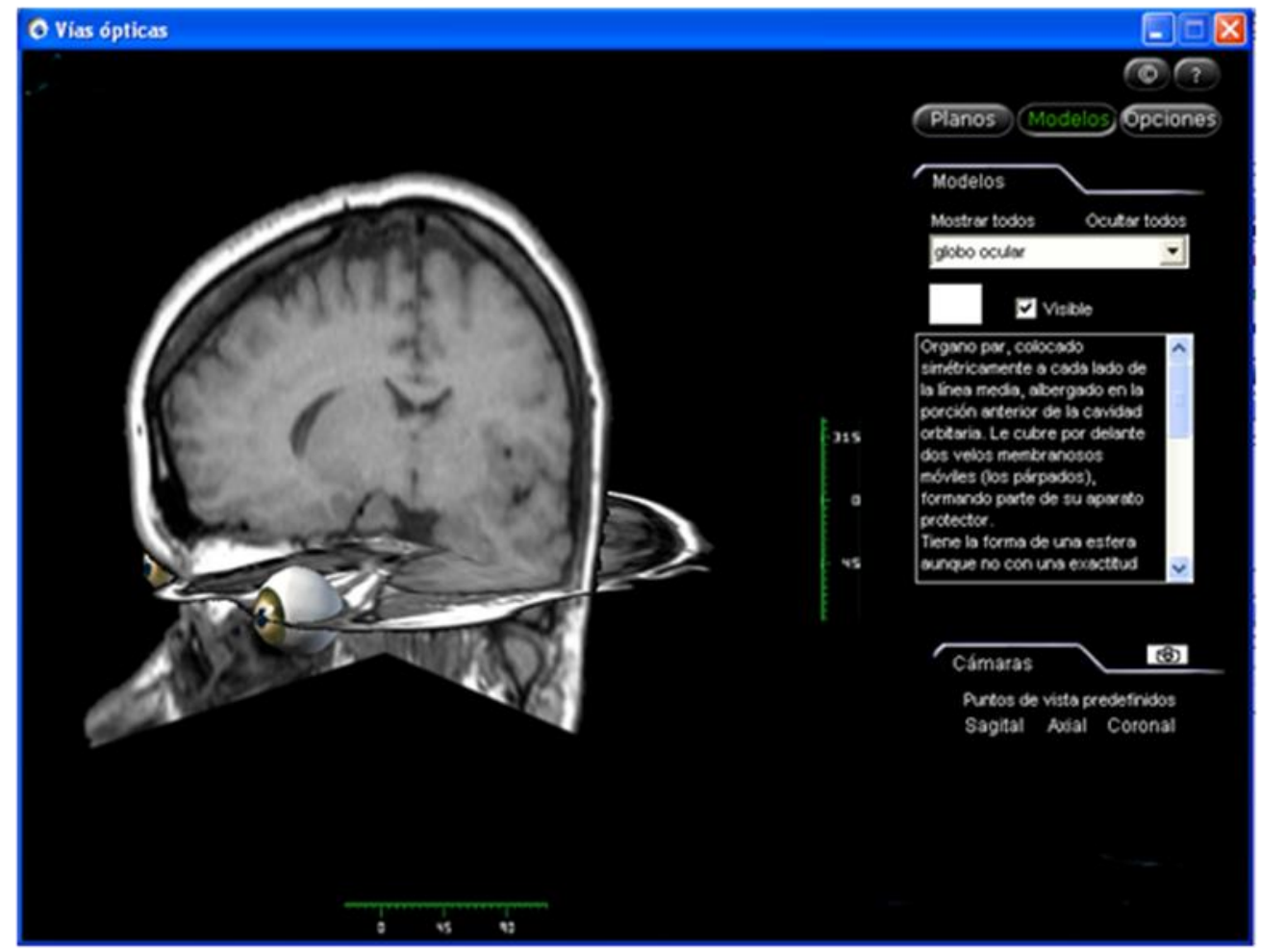

Figura 56.- Interface del desarrollo informático en el que se muestra breve descripción morfológica, en relación con el modelo 30 seleccionado. 


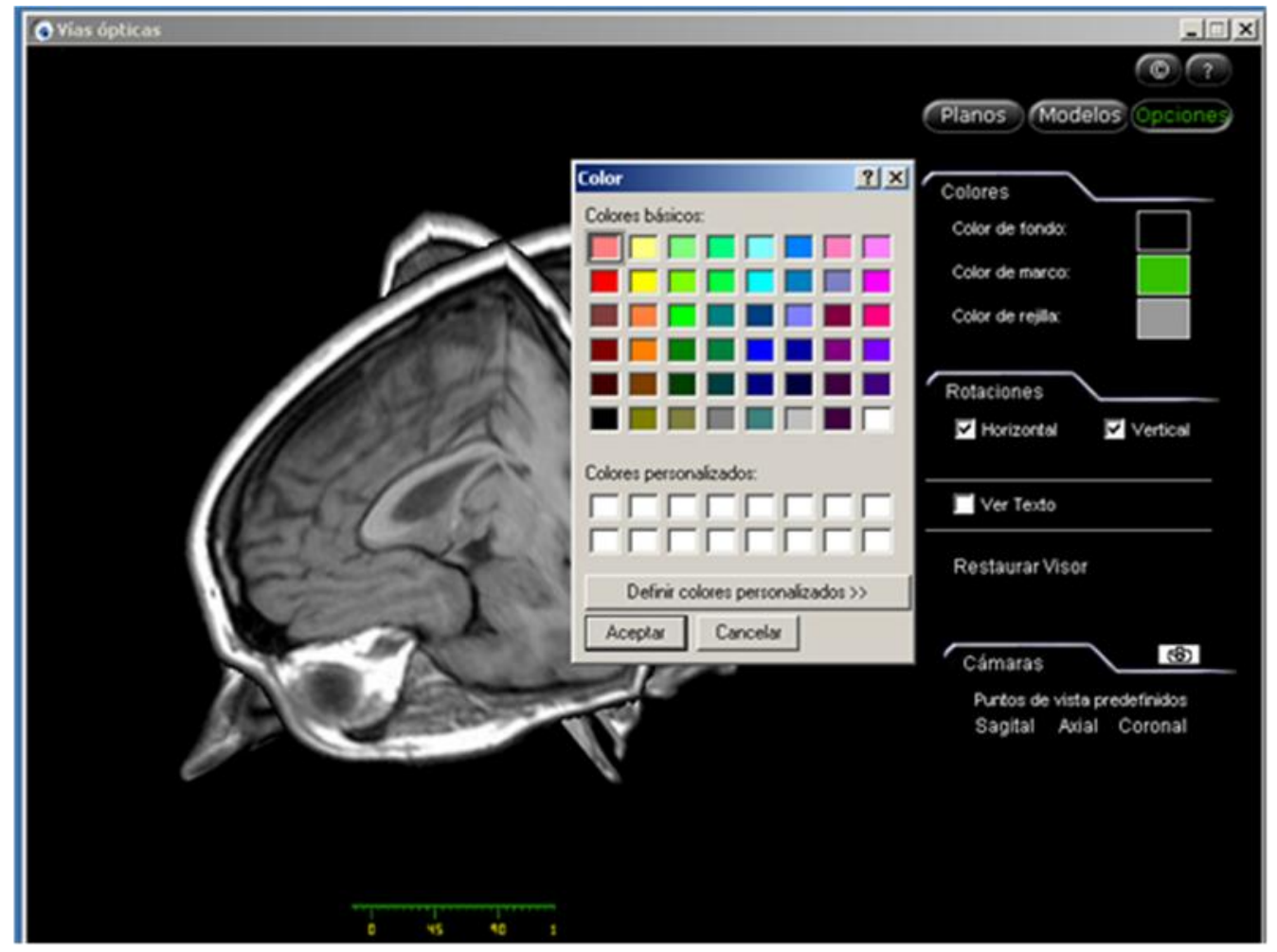

Figura 57.- Interface con opciones adicionales que presenta el desarrollo informático: color del fondo. Color de marco. Color de rejilla. El color del fondo puede ser modificado seleccionándolo en la paleta de colores.

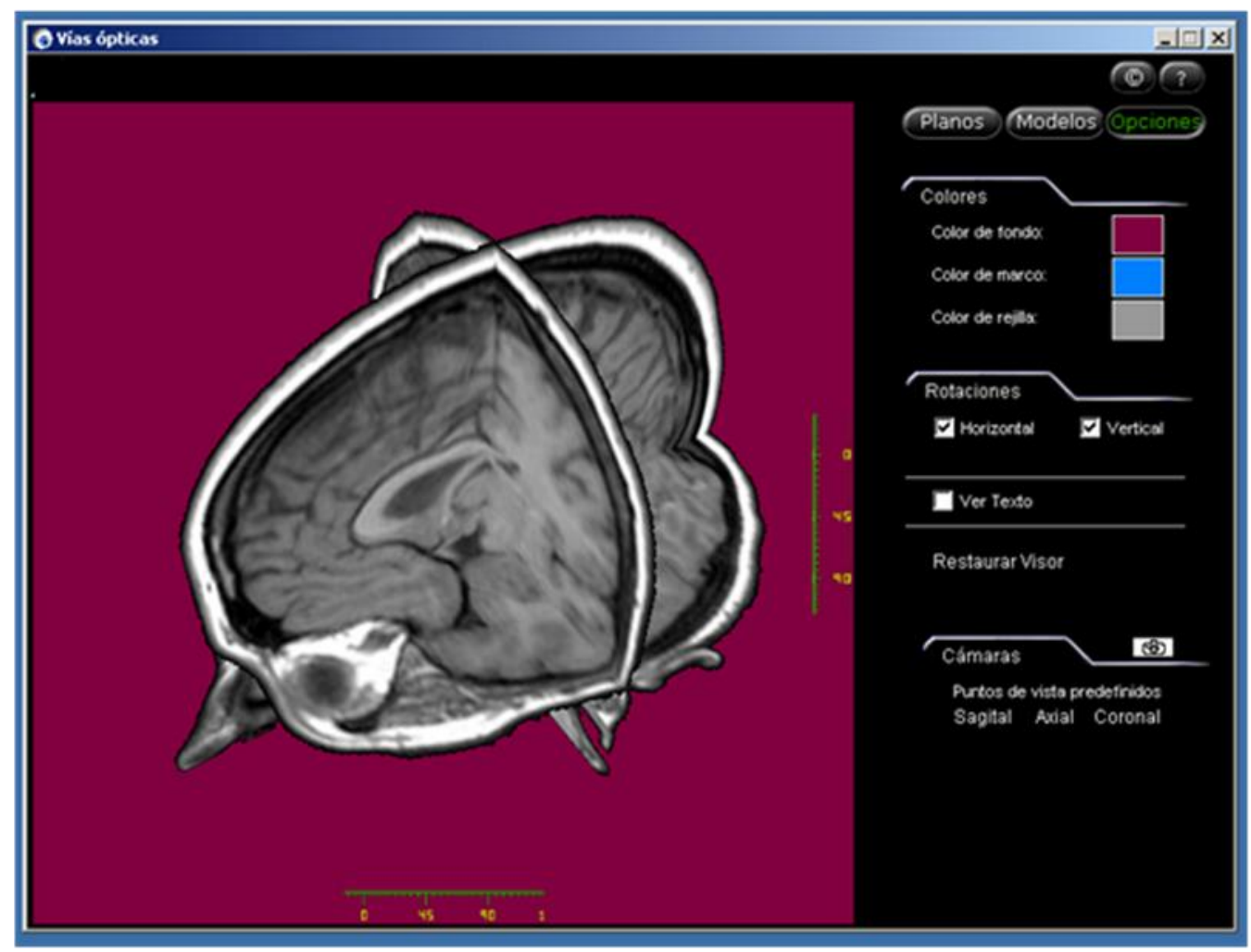

Figura 58.-Visualización del resultado de la modificación del color de fondo del visor. 


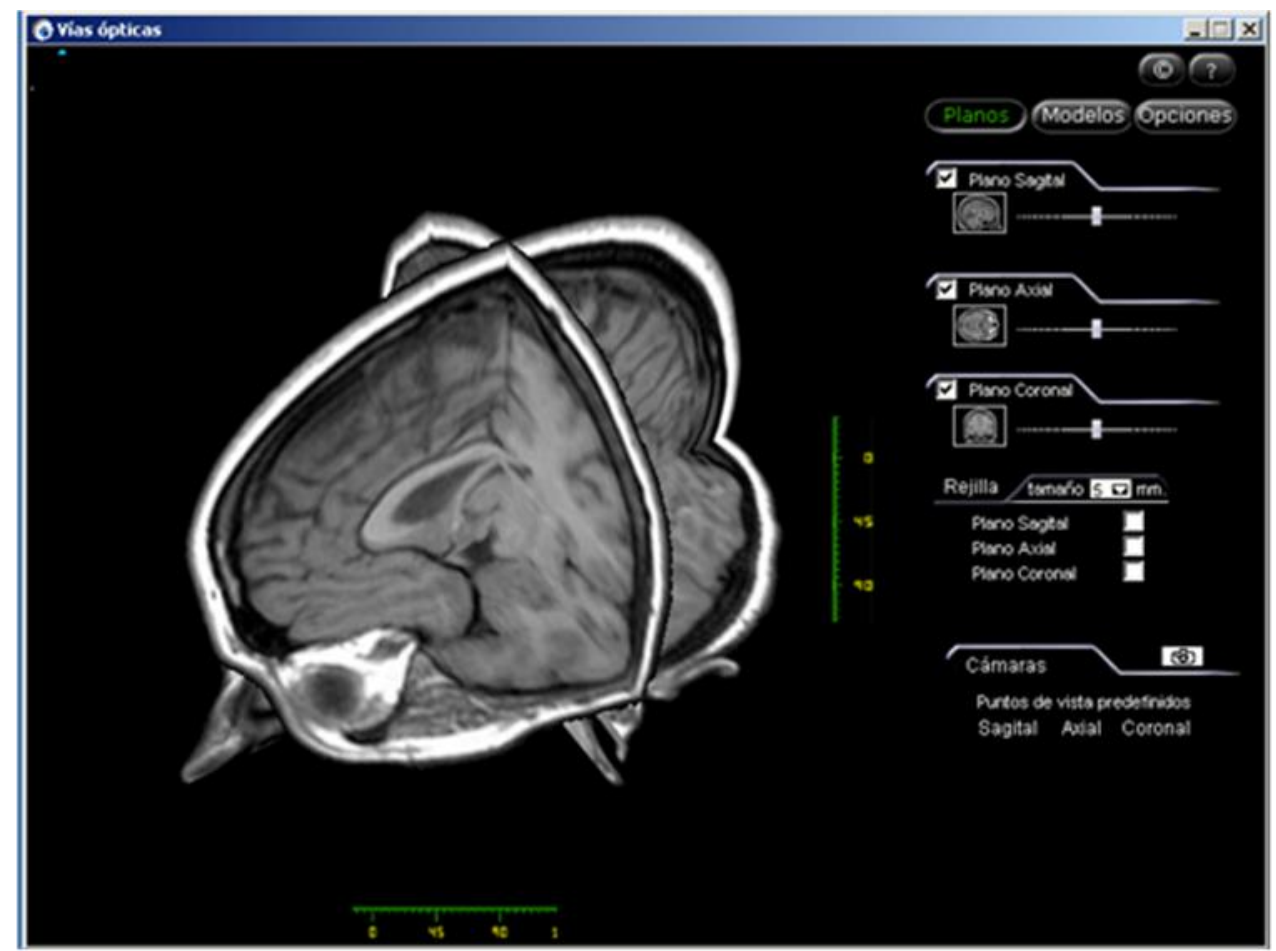

Figura 59.-Interacción de las imágenes de RM en los tres planos espaciales (axial, coronal y sagital), permitiendo la activación/desactivación, así como la selección del nivel de corte en cada plano.

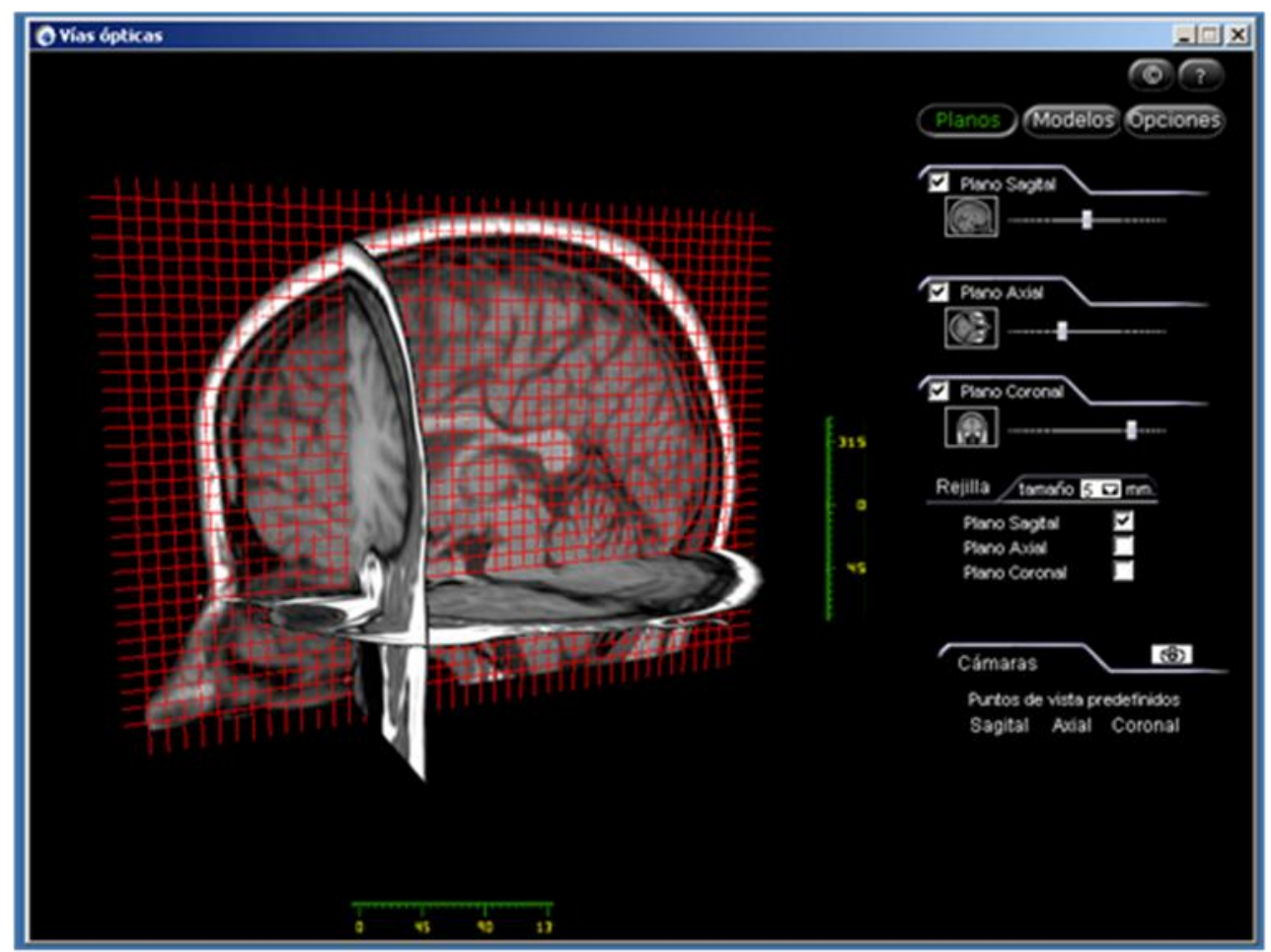

Figura 60.-Visualización de la rejilla activada en el plano sagital. El tamaño de cada cuadrícula puede variar entre 1 y $8 \mathrm{~mm}$, según la petición del usuario. El color de la rejilla puede ser igualmente modificado según la paleta de colores. 


\section{DISCUSIÓN}


Las imágenes médicas son utilizadas cotidianamente en rutina clínica para establecer un diagnóstico, escoger o controlar una acción terapéutica. La imagen médica a menudo es usada, para designar al conjunto de técnicas que producen imágenes de aspectos internos del cuerpo.

La investigación cerebral durante el último siglo ha contemplado el desarrollo de una serie de técnicas de imagen médica como la TC o la RM, que permiten conocer la morfología cerebral con alta resolución espacial, de forma que es posible identificar con precisión las alteraciones estructurales anatómicas afectas, consecuentes a los procesos patológicos.

De todas las técnicas de neuroimagen, la incorporación de la RM como técnica diagnóstica del cerebro, ha supuesto un gran impulso para el conocimiento morfológico neurorradiológico del cerebro humano.

Así, hoy en día es una técnica insustituible en la caracterización de lesiones cerebrales de todo tipo, como anomalías congénitas, tumores, patologías neurodegenerativas, procesos epilépticos, infecciosos y metabólicos. 
Por otro lado, la optimización tecnológica ha permitido obtener la mejor calidad de imagen en el menor tiempo posible. Todo ello se logra por la actualización de los propios equipos pero también la de los sistemas informáticos, que procesan las imágenes.

Los equipos de RM de alto campo, de 1.5 tesla, con morfología en cilindro, como el empleado por nosotros, ofrece mayores prestaciones, tanto desde el punto asistencial como de investigación.

Recientemente, han sido potenciadas estas técnicas de neuroimagen con el fin de producir imágenes médicas en 3D. Tradicionalmente, la TC y la RM producían salidas estáticas en 2D. Para producir imágenes 3D, se tenían que realizar muchos escaneos, que combinados por ordenador producían modelos 3D, los cuales pueden ser manipulados por el técnico que maneja el equipo o la estación de trabajo.

En este aspecto se centra nuestro trabajo de Tesis Doctoral; hemos pretendido elaborar un procedimiento informático, multidisciplinario en su participación profesional, que reconstruya toda la vía óptica y sistema oculomotor, desde imágenes médicas seccionales de resonancia magnética, a fin de aportar una nueva herramienta formativa, de ayuda al diagnóstico, a la planificación y al seguimiento terapéutico, basadas en un análisis tridimensional de imágenes médicas referenciadas con imágenes planares de RM.

En la actualidad las tecnologías de la información y la comunicación ocupan un lugar importante en la educación y formación médica, facilitando, en gran medida, el proceso de enseñanza-aprendizaje. 
Originalmente la tecnología educativa nace ligada al uso docente de los modernos medios informáticos y audiovisuales. Así queda recogido en la definición de la Organización de las Naciones Unidas para la Educación, la Ciencia y la Cultura (UNESCO, 1984).

En los años noventa se inicia la época de las telecomunicaciones en la educación. En la propia década de los noventa, la explosión tecnológica que ha ocurrido a partir del advenimiento de la microinformática, tiene como principal producto los ordenadores personales y la creación de lo que se conoce como "nuevos ambientes de aprendizaje" (De Pablos y Gortari, 1992).

No cabe duda que el ordenador es un medio por el cual el usuario (alumno) integra conocimientos, desarrolla habilidades mentales, interactúa, etc. Por otra parte habría que sumar el poder motivador y la posibilidad que brinda poder comunicarse y trabajar en equipo, lo que facilita la adquisición de conocimientos compartidos.

Pensamos que la utilización de las nuevas tecnologías en la formación ayuda a que sea posible la aplicación de metodologías docentes orientadas a la consecución de habilidades de aprendizaje que, sin las mismas no sería posible aplicar (Ortega y Martínez, 1994). Por otra parte, creemos que su utilización potencia la capacidad del profesor en su actividad docente.

Tras estas breves apreciaciones sobre la aplicación de las tecnologías a la práctica docente, estructuraremos este capítulo de discusión de nuestra Tesis Doctoral, analizando el estado actual de la aplicación de los métodos tecnológicos en la enseñanza, teniendo en cuenta y como 
referencia la aplicación informática, de carácter docente, que nosotros hemos desarrollado. Para ello, comentaremos sobre los siguientes aspectos:

Consideraciones sobre los desarrollos informáticos como recursos docentes.

Consideraciones sobre el interface de usuario empleado.

Consideraciones sobre la aportación de la RM y la imagen 3D en la práctica clínica

\section{Consideraciones sobre los desarrollos informáticos como recursos docentes:}

La enseñanza es una actividad intencional, diseñada para dar lugar al aprendizaje de los alumnos. Pero ligar los conceptos de enseñar y aprender es una manera de manifestar que la situación que nos interesa es algo más que la relación de acciones instructivas por parte del profesor y la relación de efectos de aprendizaje en los alumnos.

La mejora del aprendizaje resulta ser uno de los anhelos más importante de todos los docentes.

Los procesos de enseñanza-aprendizaje ocurren en un contexto institucional, transmitiéndole así unas características que trascienden a la significación interna de los procesos, al conferirle un sentido social.

Los procesos de enseñanza-aprendizaje pueden interpretarse bajo las claves de los sistemas de comunicación humana, teniendo en cuenta las 
peculiaridades especificas de aquéllos, una de las cuales es su carácter de comunicación intencional. La intencionalidad nos remite tanto a su funcionalidad social como a su pretensión de hacer posible el aprendizaje.

El sentido interno de los procesos de enseñanza-aprendizaje está en hacer posible el aprendizaje.

El docente debe prever, seleccionar y organizar los recursos didáctico-pedagógicos que integrarán cada situación de aprendizaje, con la finalidad de crear las mejores condiciones para lograr los objetivos previstos.

La informática como recurso didáctico-pedagógico va adquiriendo un papel más relevante a medida que la moderna tecnología se va incorporando a la tarea educativa (Rivera Porto, 1993; Marqués, 1999; Rodríguez Llamas, 2002).

La revolución de la informática médica, iniciada hace muchos años (Grémy, 1986) e intensificada, en la última década, mediante el incesante progreso de las nuevas tecnologías y las redes de comunicación en las que se desenvuelven las diferentes actividades de las ciencias de la salud, han abierto una revolución en la formación médica.

Los programas informáticos, como recursos didácticos en la formación médica, constituyen una herramienta muy útil en todas las materias de las ciencias de la salud (Grémy, 1986; Anderson y Jay, 1987; Shortliffe y Perreault, 1990).

Entre las aplicaciones más destacadas que ofrecen la utilización de las tecnologías informáticas al terreno formativo se encuentran los recursos 
de características hipermedia (Salinas, 1994), los cuales se insertan rápidamente en el proceso de enseñanza-aprendizaje de los usuarios que los manejan. Esto es así, porque refleja fielmente la manera en que el alumno o usuario, piensa, aprende y recuerda, con los programas informáticos al explorar fácilmente textos, imágenes, sonidos, animaciones y videos, para estudiar, analizar, reflexionar e interpretar en profundidad la información utilizada (Bartolomé, 1989; Vivancos Martí, 1996; Villar y Mínguez, 1998)

En consecuencia, la tecnología multimedia e hipermedia, se convierte en una poderosa y versátil herramienta que transforma a los usuarios (alumnos, residentes, especialistas, etc.) de receptores pasivos de la información en participantes activos, en un enriquecedor proceso de aprendizaje en el que desempeña un papel primordial la facilidad de relacionar sucesivamente distintos tipos de información, personalizando la formación, al permitir a cada usuario avanzar según su propia capacidad (Vivancos Martí, 1996; Squires y Preece, 1996).

Pero queremos reflejar que, la mera aplicación de estas tecnologías en la formación médica, no asegura la obtención de mejores alumnos, si entre otros requisitos dichos procesos no van guiados y acompañados por la labor y la participación activa del docente que es quién coordina y dirige toda la acción didáctica. El docente debe seleccionar cuidadosamente todo el material y el contenido docente que deben incluirse en los programas informáticos para que el usuario los estudie y aprenda con ellos.

Por eso, es necesario, que los desarrollos informáticos, de características docentes, establezcan una metodología de estudio y de 
aprendizaje para que el alumno no convierta la información brindada a través de un programa informático en un simple libro animado, en el que el usuario consuma grandes cantidades de información que no aporten demasiado a su formación médica personal (Anderson y Jay, 1987).

Por tanto, sobre todo el docente tendrá la precaución no sólo de examinar cuidadosamente los contenidos de cada material a utilizar para detectar posibles errores, omisiones, ideas o conceptos equívocos, sino que también deberá fomentar entre los alumnos una actitud de juicio crítico frente a lo que estudia con el empleo de material didáctico tecnológico (Avolio, 1981).

Cada día, aparece gran variedad de software educativo en el terreno médico, lo que permite generar una amplia base documental de desarrollos informáticos que facilitan y mejorar el aprendizaje. De esta forma, además, los alumnos podrán ir adquiriendo las habilidades y destrezas que seguramente manejaran en su actividad profesional.

Las expresiones software educativo, programas educativos y programas didácticos o docentes, se emplean como sinónimos para designar genéricamente los programas para ordenador creados con la finalidad específica de ser utilizados como medio didáctico, es decir, para facilitar los procesos de enseñanza y de aprendizaje (Castillejo, 1986).

Esta definición engloba todos los programas que han estado elaborados con un fin didáctico, desde los tradicionales programas basados en los modelos conductistas de la enseñanza, conocidos clásicamente como programas de Enseñanza Asistida por Ordenador (EAO), hasta los programas experimentales de Enseñanza Inteligente 
Asistida por Ordenador (EIAO), que, utilizando técnicas propias del campo de los Sistemas Expertos y de la Inteligencia Artificial en general, pretenden imitar la labor tutorial personalizada que realizan los profesores y presentan modelos de representación del conocimiento en consonancia con los procesos cognitivos que desarrollan los alumnos.

Lo que parece evidente, es que los modernos programas informáticos docentes que surgen en el campo de la medicina, favorecen la flexibilidad del pensamiento de los usuarios que los emplean, ya que estimulan la búsqueda de distintas soluciones para una misma actividad planteada, permitiendo un mayor despliegue de los recursos cognitivos de los alumnos.

La utilización del ordenador en las aulas implica un mayor grado de abstracción de las acciones, una toma de conciencia y anticipación de lo que muchas veces hacemos "automáticamente"; de esta forma conseguiremos estimular en nuestros alumnos las conductas operatorias (actúa y toma decisiones) en lugar de las conductas sensorio-motoras (sólo escucha y escribe).

Por otro lado, desde el punto de vista afectivo y social, el manejo de programas informáticos docentes, permite el trabajo en equipo, apareciendo así la cooperación entre sus usuarios y la posibilidad de intercambiar puntos de vista entre los alumnos, lo cual favorece también, sin lugar a dudas, sus procesos de enseñanza-aprendizaje. De esta forma, el alumno es un sujeto activo y participante de su propio aprendizaje que puede desarrollar usos y aplicaciones de lo que estudia a través de la inserción de las nuevas tecnologías. 
El ordenador, a través de los programas formativos, constituye además, para el docente, un instrumento capaz de revelar, paso a paso, el avance intelectual de sus alumnos.

Pero para favorecer este proceso de enseñanza-aprendizaje de los alumnos de una titulación, el docente deberá ser, ante todo, una persona capaz de acompañar a sus alumnos en este crecimiento de aprendizaje que van realizando. Deberá ser capaz de plantear conflictos cognitivos y dudas que les surjan a los alumnos, apoyándolos en la construcción de sus estructuras de conocimientos. También deberá colaborar con ellos para que integren el error como parte del proceso de aprendizaje que están llevando a cabo, impulsándolos a reflexionar sobre la lógica de sus equivocaciones.

Los docentes de hoy se encuentran ante un volumen creciente de materiales curriculares y elementos auxiliares de enseñanza: libros de texto, ordenadores, software educativo, medios audiovisuales. Sin embargo, disponen de pocas referencias de utilidad general que pudieran ayudarlos a hacer sus selecciones; algunas de ellas, significan decisiones sobre lo que se va a enseñar; otras encierran selecciones de medios en los cuales el contenido, ya elegido, ha de ser presentado. Para muchos profesores, muchas de estas ideas modernas, son difíciles de entender, de aceptar y de armonizar con los antiguos conceptos de educación adquiridos por los docentes. Un particular criterio a desarrollar en los docentes, ha de ser el de elegir adecuadamente los diferentes software educativos a emplear en la formación de sus alumnos, considerando el nivel de estos, la didáctica de enseñanza y los requerimientos técnicos para su correcta utilización como apoyo a la docencia. 
La evolución experimentada, durante los últimos años, en la implementación de proyectos de informática educativa, promueve el desarrollo de diversas acciones entre las cuales es necesario destacar la disponibilidad de equipamiento informático adecuado, la utilización del software más conveniente, el debido mantenimiento y asistencia técnica de ambos y por último, pero no menos importante, la vigencia de un proyecto institucional promovido por las autoridades universitarias del centro y de la institución general, así como la formación y capacitación de los propios docentes.

Pero debemos tener en cuenta que, la mera incorporación de las nuevas tecnologías informáticas a las diversas actividades que se desarrollan habitualmente en la formación académica de nuestros alumnos, no logra satisfacer las expectativas creadas, si no se tiene en consideración la indispensable necesidad de capacitar simultáneamente los recursos humanos disponibles, a través de un permanente plan de formación y capacitación que incluya el desarrollo de cursos y encuentros que contemple no sólo los aspectos informáticos, sino también los didácticos.

\section{Estructura de los programas informáticos docentes:}

La mayoría de los programas didácticos, igual que muchos de los programas informáticos nacidos sin finalidad educativa, tienen tres módulos principales claramente definidos: el módulo que gestiona la comunicación con el usuario, el módulo que contiene debidamente organizados los contenidos informativos del programa y el módulo que gestiona las actuaciones del ordenador y sus respuestas a las acciones de los usuarios. 
Los programas establecen un diálogo con sus usuarios, a través de un entorno que posibilita la interactividad entre ambos (máquina y usuario). Este entorno de programación consta de un sistema de comunicación que facilita la transmisión de informaciones al usuario por parte del ordenador. Incluye el uso del teclado y el ratón, mediante los cuales los usuarios introducen al ordenador un conjunto de órdenes o respuestas que los programas reconocen.

Con la ayuda de las técnicas de la Inteligencia Artificial y del desarrollo de las tecnologías multimedia, se investiga la elaboración de entornos de comunicación cada vez más intuitivos y capaces de proporcionar un diálogo abierto y próximo al lenguaje natural.

Los programas educativos a pesar de tener unos rasgos esenciales básicos y una estructura general común se presentan con unas características muy diversas: unos aparentan ser un laboratorio o una biblioteca, otros se limitan a ofrecer una función instrumental del tipo máquina de escribir o calculadora, otros se presentan como un juego o como un libro, muchos tienen aspecto de examen, unos pocos asemejan ser sistemas expertos, etc. Pero la mayoría de ellos participan, en mayor o menor medida, de algunas de estas peculiaridades citadas anteriormente.

Los programas docentes pueden catalogarse en distintas categorías, así podemos hablar de programas tutoriales, programas no directivos, programas abiertos o cerrados, etc. (Shortliffe y Perreault, 1990).

Programas tutoriales directivos, que hacen preguntas a los estudiantes y controlan en todo momento su actividad. El ordenador adopta el papel de juez poseedor de la verdad y examina al alumno. Se 
producen errores cuando la respuesta del alumno está en desacuerdo, con la que el ordenador tiene como correcta. En los programas más tradicionales el error lleva implícita la noción de fracaso.

Programas no directivos, en los que el ordenador adopta el papel de un laboratorio o instrumento a disposición de la iniciativa de un alumno que pregunta y tiene una libertad de acción sólo limitada por las normas del programa. El ordenador no juzga las acciones del alumno, se limita a procesar los datos que éste introduce y a mostrar las consecuencias de sus acciones sobre un entorno. Objetivamente no se producen errores, sólo desacuerdos entre los efectos esperados por el alumno y los efectos reales de sus acciones sobre el entorno. No está implícita la noción de fracaso. El error es sencillamente una hipótesis de trabajo que no se ha verificado y que se debe sustituir por otra. En general, siguen un modelo pedagógico de inspiración cognitivista, potencian el aprendizaje a través de la exploración, favorecen la reflexión y el pensamiento crítico y propician la utilización del método científico.

Otra clasificación interesante de los programas atiende a la posibilidad de modificar los contenidos del programa y distingue entre programas cerrados (que no pueden modificarse) y programas abiertos, que proporcionan un esqueleto, una estructura, sobre la cual los alumnos y los profesores pueden añadir el contenido que les interese. De esta manera se facilita su adecuación a los diversos contextos educativos y permite un mejor tratamiento de la diversidad de los estudiantes.

No obstante, de todas las clasificaciones la que posiblemente proporciona categorías más claras y útiles a los profesores es la que tiene 
en cuenta el grado de control del programa sobre la actividad de los alumnos y la estructura de su algoritmo.

Los programas informáticos docentes basados en simulaciones, presentan un entorno dinámico (generalmente a través de gráficos o animaciones interactivas) y facilitan su exploración y modificación a los alumnos, que pueden realizar aprendizajes inductivos o deductivos mediante la observación y la manipulación de la estructura subyacente; de esta manera pueden descubrir los elementos del modelo, sus interrelaciones, y pueden tomar decisiones y adquirir experiencia directa delante de unas situaciones que frecuentemente resultarían difícilmente accesibles a la realidad, como puede ser la posibilidad de simular un abordaje quirúrgico de forma virtual.

El desarrollo de aplicaciones informáticas avanzadas para el estudio de distintos aspectos anatómicos corporales, están siendo introducidas, de forma progresiva en el terreno médico, generándose programas muy valiosos para el estudio anatomo-radiológico (Juanes y col., 1996; Juanes y col., 2001).

El software que hemos desarrollado está orientado hacia un modelo centrado en el usuario, basándose en el autoaprendizaje y la autoformación sobre la vía óptica y el sistema oculomotor.

Para el desarrollo de nuestra aplicación informática, hemos utilizado tecnología informática, de última generación, empleando para su elaboración, software de creación propia, así como estándares del mercado, con el fin de que nuestro desarrollo informático se presentase 
en un soporte compatible con la mayoría de los equipos informáticos y con las diferentes versiones del sistema operativo Windows.

Hoy en día, las encuestas sobre satisfacción y los cuestionarios se utilizan cada vez con mayor frecuencia. Estas encuestas son un vehículo importante para recoger las opiniones de los usuarios. Nos permiten capturar información rápidamente con un coste y esfuerzo relativamente mínimos, obteniendo, de esta forma una valoración sobre una aplicación informática probada por diferentes usuarios.

Para obtener una valoración de nuestro desarrollo informático llevamos a cabo una pequeña encuesta de satisfacción, con el objetivo de recoger la opinión del programa, de algunos usuarios y sin buscar un análisis estadístico exhaustivo de la aplicación informática elaborada. Por ello, esta encuesta fue practicada sobre un grupo de personas voluntarias $(n=60)$, de los servicios de oftalmología de diferentes centros hospitalarios nacionales y estudiantes de 5o curso de Medicina. Esta encuesta nos reveló una buena apreciación de nuestro procedimiento informático, mostrando un alto grado satisfacción con el desarrollo didáctico empleado. De esta forma, podemos señalar que el desarrollo informático realizado ha cumplido con los objetivos que nos habíamos marcado, es decir, a través de programa hemos proporcionado una herramienta para adquirir adecuadamente y visualmente los conocimientos anatómicos sobre la compleja vía óptica y sistema oculomotor, mediante la observación en diferentes posiciones, en 3D y correlacionadas con secciones de resonancia magnética en los tres planos espaciales. Por otro lado, pensamos que se ha construido un material que permite desarrollar capacidades y destrezas a través de la utilización de los sistemas 
informatizados de simulación gráfica y visualización espacial, que desde un punto de vista docente, facilita el proceso de enseñanza-aprendizaje de estas estructuras anatómicas. Además, hemos podido constatar en los usuarios que la han manejado un aumento de la motivación para el estudio, proporcionándoles un recurso adicional de aprendizaje y destreza en el conocimiento de la vía óptica y estructuras del sistema oculomotor.

Tras la experiencia realizada con nuestro trabajo, podemos señalar que nuestro procedimiento docente constituye una herramienta informática de formación médica, rigurosamente cuidada y elaborada, y en la que han participado y colaborado diferentes profesionales en su desarrollo (anatomistas, oftalmólogos, radiólogos e informáticos), para que los usuarios, puedan desarrollar, de forma autónoma, todo el proceso de enseñanza-aprendizaje como si estuviera guiado por el profesional docente, que es quien ha coordinado y controlado toda la acción didáctica.

Cada día surgen nuevas plataformas informáticas como estructuras coordinadas de software y hardware que proveen la base para la construcción de sistemas de información para la formación médica. La incorporación de las tecnologías informáticas al campo de la medicina supone un recurso útil y atractivo en cualquier área de las ciencias de la salud. Por tanto, la formación y documentación con el apoyo de métodos tecnológicos, a través de programas informáticos interactivos, favorece el proceso de formación de los usuarios de estos recursos tecnológicos. 


\section{Consideraciones sobre el interface de usuario empleado:}

La rápida expansión de las tecnologías de la información plantea nuevas demandas para el software que ha de mediar entre las aplicaciones y las personas. Las nuevas aplicaciones tienen que manejar una información sujeta a variaciones, dispersa y heterogénea, y responder a la creciente diversificación de usuarios y plataformas. A nivel de las interfaces de usuario, esto significa que en muchos casos no es posible concebir de antemano soluciones satisfactorias en términos de una presentación gráfica fija y una estructura predeterminada de diálogo con el usuario.

El diseño de un interface de usuario es una tarea compleja y a menudo mal comprendida, en el diseño de aplicaciones informáticas de características docentes. El interface es particularmente importante para establecer una vinculación amigable entre el usuario el ordenador y la aplicación informática.

Las herramientas de desarrollo de interfaces de usuario, de uso común hoy en día, no dan un soporte adecuado para este tipo de necesidades, por lo que o bien se producen soluciones obsoletas, o bien una gran parte del desarrollo se lleva a cabo con lenguajes programación de propósito general, dando lugar a un desarrollo difícil, costoso, y propenso a errores. La creación de herramientas de alto nivel para el desarrollo de interfaces que soporten expresamente los aspectos 
dinámicos es un problema difícil en general, por lo que sigue siendo un campo activo de investigación.

En este trabajo de Tesis Doctoral hemos descrito y analizado lo realizado por nuestro grupo en la línea del desarrollo de nuevas herramientas de diseño y soporte de interfaces que, en uno u otro aspecto, son capaces de definir, ajustar o ampliar su propia estructura y funcionalidad.

Muchas veces, en la generación de programas informáticos didácticos, se utiliza una gran cantidad de tiempo en el diseño de los datos y el esqueleto de la aplicación informática, pero se usa muy poco tiempo en el diseño del interface de usuario (Cooper, 2004).

La historia reciente de la informática está indisolublemente unida a las interfaces gráficas, puesto que los sistemas operativos gráficos han ocasionado grandes consecuencias en la industria del software y del hardware.

El interface de usuario constituye el elemento clave de todo desarrollo informático, ya que es el mediador entre la máquina y el usuario, facilitando la comunicación o interacción entre dos sistemas, el ser humano y el ordenador.

Este entorno de comunicación medido por el interface, constituye un conjunto de componentes (iconos, textos, ...), empleados por los usuarios para comunicarse con el desarrollo informático que está ejecutando en el ordenador (Shneiderman, 1998). Los iconos no son meros elementos decorativos, sino parte esencial de los mecanismos de interacción de 
cualquier interface, que deben ser diseñados cuidadosamente. Aunque los iconos tienen limitaciones, su uso adecuado aporta grandes ventajas. Es, por tanto, el usuario, el que realmente dirige el funcionamiento y manejo del programa informático mediante diversas instrucciones de usabilidad, como las que nosotros hemos elaborado en nuestro procedimiento informático para el análisis de la vía óptica y sistema oculomotor.

El interface de usuario es la cara visible de un desarrollo informático y también de otros tipos de dispositivos electrónicos. Ayudan al usuario a interactuar con la máquina, expanden el rango de aplicaciones de un ordenador de forma considerable y representan una importante ayuda para el aprendizaje.

Podemos señalar, sin lugar a dudas, que el interface es la parte de una aplicación informática que el usuario ve y con la cual interactúa; estando este interface directamente relacionado con la estructura, arquitectura y código del software subyacente (Cooper, 2004).

Todo interface de usuario, incluye las pantallas, ventanas, menús, ayuda, documentación, etc., con el que el usuario ve e interactúa.

Un buen interface debe ser claro e intuitivo. Con estas intenciones hemos desarrollado y plasmado nuestro interface; buscando siempre la facilidad de manejo y permitiendo al usuario desempeñar libremente toda la tarea de aprendizaje o de formación, de la forma más sencilla, rápida e intuitiva. Estas son sin duda, unas de las principales ventajas que nuestro procedimiento informático ofrece, además del carácter visual de las imágenes tridimensionales, tal y como lo han manifestado en la encuesta llevada a cabo entre diferentes usuarios. 
Nuestro interface tiene una capacidad para ajustarse a un entorno cambiante, con una representación adecuada de sus propios componentes, tanto para actuar sobre ellos, como para construirlos o modificarlos. Está diseñado en un lenguaje textual de alto nivel, generado código $\mathrm{C}^{++}$que incorpora un sistema de programación con actuaciones sobre campos de objetos.

Inicialmente los interfaces de usuario eran desarrollados pensando solamente en su correcto funcionamiento, luego se comprobó la necesidad de que fueran fácilmente usables y después se hizo patente la importancia de la estética en los mismos, punto en el que el diseño gráfico entró de lleno en el mundo de las interfaces de usuario. Un sistema de este tipo no sólo tiene que funcionar, debe ser atractivo para el usuario, acorde con las inquietudes estéticas del mundo que nos rodea. Colores, formas, agrupaciones y comunicación forman en la actualidad parte indispensable de un interface de usuario.

La evolución de las interfaces de usuario camina en paralelo con la de los sistemas operativos; tanto es así, que la interface es actualmente uno de los principales elementos de todo sistema operativo. El sistema operativo DOS, de los primeros ordenadores personales, es el estilo más antiguo de interacción entre usuario y ordenador. El usuario escribe órdenes utilizando un lenguaje formal con un vocabulario y una sintaxis propia (los mandatos en el caso del DOS). Se usa un teclado, típicamente, y las órdenes estaban encaminadas a realizar una acción. El usuario no suele recibir mucha información por parte del sistema, y debe conocer cómo funciona el ordenador y dónde están los programas (nada está 
oculto al usuario). El modelo de la interface es el del programador, no el del usuario.

Los interfaces de menús, contienen una lista de opciones que se muestran en el monitor o en una ventana de la pantalla, para que los usuarios seleccionen la opción que deseen. Los menús permiten dos cosas: navegar dentro de un sistema, presentando rutas que llevan de un sitio a otro, y seleccionar elementos de una lista, que representan propiedades o acciones que los usuarios desean realizar sobre algún objeto.

Los menús contextuales son los más recientes. Se llaman así porque el contenido del menú depende del contexto de trabajo del usuario. Contienen únicamente las opciones que son aplicables al objeto seleccionado. Estos interfaces son los típicos del sistema operativo Windows. Este tipo de interface es el empleado por nosotros, al cual le hemos incorporado pequeños iconos ilustrativos e intuitivos de la acción a realizar, lo que facilita, sin duda, la navegación por nuestro desarrollo informático.

Como señala Royo (2004), en su libro "Diseño Digital", nosotros también pensamos que estos tipos de interfaces de menús contextuales, bien estructurados, son buenos para usuarios noveles o esporádicos. Creemos que son fáciles de aprender y de recordar; pudiendo existir menús simples y avanzados, para adaptarse al tipo de usuario.

Las recomendaciones para este tipo de interfaces es no ocupar demasiado espacio de la pantalla, recordar la información acumulada de 
menús precedentes, no colocar demasiados elementos en el menú y agruparlos de manera lógica.

Otro grupo de interfaces son los denominados gráficos, conocidos con las siglas, GUIs (graphical user interfaces). Estos interfaces fueron desarrollados inicialmente por XEROX (sistema Xerox Star, 1981), aunque su popularización se debió a Apple. Steven Jobs se inspiró en los trabajos de Xerox y creó el Apple Lisa, 1983, sin éxito, y Apple Macintosh, 1984, con éxito debido en gran medida a su campaña publicitaria.

Un GUI es una representación gráfica en la pantalla del ordenador de los programas, datos y objetos, así como de la interacción con ellos. Un GUI proporciona al usuario las herramientas para realizar sus operaciones, más que una lista de las posibles operaciones que el ordenador es capaz de hacer.

Una característica importante de las GUI es que permite manipular los objetos e información de la pantalla del ordenador, y no sólo presentarla. No obstante, a nuestro parecer, sería muy recomendable que cualquier usuario que utilizara nuestra aplicación o cualquier otra de estas características técnicas conociera una serie de conceptos como son la organización del sistema operativo que maneja, diferentes tipos de iconos que aparecen en el programa, así como el efecto de las acciones que hacen cuando se pulsa sobre ellos, elementos básicos de una ventana, uso adecuado del ratón (sobre todo en aplicaciones como la nuestra en el que toda la manipulación de las imágenes se realiza a través de él). 
Es precisamente en este prototipo de interface gráfico, en el que nos hemos basado para nuestro desarrollo informático; el cual, entre las características más relevantes podríamos destacar los siguientes aspectos:

$\checkmark$ Ejecutable y visible en un monitor gráfico de alta resolución.

$\checkmark$ Opera con un dispositivo apuntador (ratón).

$\checkmark$ Los usuarios pueden ver en la pantalla las imágenes y textos tal como los vería impresos.

$\checkmark$ Sigue el paradigma de la interacción objeto-acción.

$\checkmark$ Permite la transferencia de información entre programas, ya que el usuario puede capturar y archivar imágenes, en formato .bmp).

$\checkmark$ Puede manipular sobre la pantalla del ordenador las estructuras anatómicas tridimensionales generadas variando su plano de visión, a gusto del usuario.

$\checkmark$ Existe una muestra visual de la información y de los modelos anatómicos 3D a través de iconos intuitivos.

$\checkmark$ Proporciona una respuesta visual a las acciones del usuario, de forma rápida (secciones de RM en los tres planos espaciales, rotaciones de imagen, translaciones, zoom, etc.).

$\checkmark$ Existen controles gráficos para la selección de la información.

$\checkmark$ Proporciona una excelente flexibilidad con el uso del ratón, para la navegación por el programa.

En la actualidad, los interfaces más usados son sin duda los de Microsoft Windows XP, pero con la aparición de Microsoft Vista, el 
sistema XP, sin duda, empezará a ser sustituido. Incluso, las perspectivas de futuro apuntan hacia la utilización de interfaces de software libre. No obstante, lo que parece claro es que esta nueva hornada de interfaces que está por llegar en los próximos años no será esencialmente diferente de lo que conocemos hoy en día. Un cambio radical de concepción está aún bastante lejano en el tiempo, por lo menos para lo que son los estándares en informática. Por otra parte, no se conoce, hasta la fecha actual, ningún desarrollo informático serio que se esté llevando a cabo en ese sentido.

Es de suponer que la evolución de los interfaces gráficas pase por la adopción de las tres dimensiones y de nuevos paradigmas, alejados ya de los tradicionales.

En nuestra opinión, sería muy interesante que la nueva generación de GUls permitiese manipular la información de formas no ligadas a la realidad cotidiana, sino adaptadas a lo que es, algo mucho más abstracto. Así se podría pasar a un nuevo nivel de uso de las computadoras, haciendo previsiblemente más sencilla la manipulación de grandes cantidades de información y aumentando la productividad.

\section{Consideraciones sobre la aportación de la RM y la imagen 3D en la práctica clínica:}

La RM de alta resolución que utiliza secuencias spin-eco sin realce de contraste es capaz de marcar el trazado de vasos y nervios orbitarios (Ettl y col., 1997 a; 1998 a) y de representar los detalles de los músculos extraoculares y de su sistema conectivo (Ettl y col., 1997 b; 1998 b). 
La excelente visualización de los detalles de los tejidos blandos se basa en los siguientes principios: a) apariencia oscura de los vasos con sangre circulante debido al vacio de señal que emiten; b) el alto y brillante background de la grasa orbitaria en imágenes RM potenciadas en T1, permitiendo un excelente contraste con los tejidos blandos orbitarios; c) la posibilidad de emplear cortes relativamente gruesos, de unos $3 \mathrm{~mm}$, permite visualizar largos segmentos de vasos u nervios; como inconveniente del grosor se halla la disminución en la resolución espacial, no obstante, el empleo de bobinas de superficie orbitaria mejora la relación señal/ruido y, por consiguiente, la resolución de los detalles (Ettl y col., 2000 a).

En términos generales, las imágenes ponderadas en T1 dejan ver estructuras anatómicas mejores que las expuestas mediante ponderación en T2; por el contrario las imágenes RM potenciadas en T2 son muy sensibles a la patología y pueden detectar lesiones que no serían visibles o muy difícilmente apreciables en imágenes potenciadas en T1. Además, las porciones subaracnoideas de los nervios craneales, incluidos los motores oculares, son mejor visualizados en $\mathrm{T} 2$ debido al excelente contraste entre el liquido cefalorraquídeo y los nervios que muestran una intensidad de señal media. Las porciones intracavernosas de los nervios motores oculares son visualizadas mejor sobre estudios de RM realzados con contraste (Ettl y col., 2000 b).

El nervio óptico es filogenéticamente una evaginación encefálica; así, la estructura histológica y el espectro tumoral que asienta en este par craneal son análogos a los del tejido nervioso central (meningiomas, gliomas) mientras que en los restantes pares craneales (Wichman y 
Müller-Forell, 2004), incluidos el III, IV y VI, los tumores que en ellos surgen son de tipo nervioso periférico (Schwanomas, neurofibromas).

Las porciones intraorbitaria y canalicular del nervio óptico están rodeadas por las hojas meníngeas aracnoides y dura madre, formadas a partir de extensiones de las correspondientes estructuras endocraneales, constituyendo un espacio subaracnoideo tubular en torno al nervio óptico. La piamadre que envuelve al II par craneal recubre también a los vasos retinianos.

En el anillo tendinoso común las inserciones de los músculos rectos superior y medial están en íntima relación con la duramadre de la porción posterior intraorbitaria del nervio óptico, lo cual explica el típico dolor orbitario que surge en las neuritis retrorbitarias, exacerbado con los movimientos oculares (Bron y col., 1997).

La porción intracraneal del nervio óptico se aprecia en las RM discurriendo por el surco quiasmático, o justo por detrás, junto al diafragma selar (Renn y Rhoton, 1975) y se une al del lado opuesto para formar el quiasma óptico. El tracto o cintilla óptica parte de la porción posterior del quiasma y se extiende dorsolateralmente, a ambos lados del tuber cinereum, por detrás de la sustancia perforada anterior hasta terminar, mayoritariamente, en el núcleo geniculado lateral, como se aprecia fácilmente en las RM (Horton y col., 1990; Fujita y col., 2001).

Con secuencias adecuadas de RM, especialmente las de alta resolución y potenciadas en $\mathrm{T} 2$, pueden distinguirse las radiaciones ópticas, partiendo de los núcleos geniculados laterales, en forma de fibras bien empaquetadas y altamente mielinizadas, que discurren en paralelo 
embebidas en sustancia blanca dispuesta a su alrededor de forma más dispersa (Cunes y col., 1988). La presencia de edema o gliosis en la sustancia blanca limitante permite distinguir fácilmente entre el tapetum y las radiaciones ópticas (Kitajima y col., 1996). Por detrás del estrato sagital, las fibras de las radiaciones ópticas se vuelven mediales y se proyectan al cortex visual primario, abriéndose en abanico y perdiendo la típica apariencia en RM de haz densamente mielinizado y diferenciable de las sustancia blanca circundante (Wichmann y Müller-Forell, 2004).

Con RM de alta resolución es posible demostrar la estría intracortical de Gennari, por las mismas características fenomenológicas que las descritas para la RM de las radiaciones ópticas. No obstante, la mieloarquitectura intracortical es más fácil de quedar representada en los cortes de RM de muestras cadavéricas que in vivo, en el cual pude solo distinguirse ligeramente (Clark y col., 1992).

Las imágenes de RM aportan información muy importante bajo circunstancias específicas como sospechas de cuerpos extraños en la órbita, hemorragia en la vaina del nervio óptico, lesiones vasculares. La RM de alta resolución puede demostrar una relación entre lesiones que ocupan espacio con estructuras anatómicas específicas, las cuales pueden ayudar al diagnóstico de lesiones como tumores neurogénicos o anomalías venosas. También es útil la RM en lesiones orbitarias en las que se sospecha una extensión intracraneal.

De gran valor son las imágenes de RM del nervio óptico, especialmente en sus porciones intracanalicular e intracraneal. El espacio subaracnoideo del nervio óptico intraorbitario puede trazarse sobre imágenes ponderadas en T2 y medir los diámetros pial dural del nervio 
(Ettl y col., 1998 c). Los agentes de contraste paramagnéticos pueden realzar selectivamente las lesiones patológicas de un nervio (neuritis, glioma) o de su vaina (meningiomas del nervio óptico),(Mafee y col., 1999).

La RM puede revelar anormalidades de los músculos extraoculares, incluyendo cambios de su recorrido o de sus poleas (Demer y col., 1995). Además el potencial contráctil de los músculos extraoculares puede determinarse midiendo su área de sección transversal en diferentes posiciones de la mirada (Demer y Miller, 1995). Se han encontrado heterotopia de las poleas musculares en modelos de estrabismo (Clark y col., 1998) y miopía (Krzizok y col., 1997). También la RM puede visualizar delicados septos fibrosos para diferenciar entre desórdenes de la motilidad restrictiva y parética. La MR de alta resolución puede visualizar de forma individual a los nervios motores intraorbitarios, lo cual permite una localización exacta de las lesiones nerviosas en pacientes con parálisis musculares oculares (Ohtsuka y col., 1997).

La importancia de la RM en la clínica de la vía óptica y de los sistemas neuromusculares extraoculares, estriba en ser una técnica de diagnóstico no invasiva que permite la delineación exacta de procesos que ocupan espacios orbitarios en relación a las estructuras anatómicas que les rodea. Esta característica es importante para la planificación quirúrgica, especialmente cuando se emplean sistemas de neuronavegación. Además, la RM de alta resolución tiene el potencial de demostrar causas anatómicas de desordenes motores musculares (Ettl y col., 2000 a).

El desarrollo de las nuevas generaciones de equipos radiológicos como la RM o como la TC helicoidal multicorte en los últimos años, junto 
con la mejora de los soportes informáticos ha supuesto una espectacular evolución en el procesado de imagen y la expansión de las imágenes tridimensionales, generándose este tipo de imágenes en menor tiempo y con mayor resolución (Kaufman, 1991).

Para lograr imágenes tridimensionales de calidad es necesaria una correcta adquisición de los datos axiales, lo que en los equipos de última generación podemos conseguir en un corto espacio de tiempo. Este volumen de datos obtenido se transfiere a una estación de trabajo donde se procesarán las imágenes axiales para obtener reconstrucciones multiplanares y 3D (Jayaram, 1999).

Las imágenes en 3D pueden ser generadas por una gran variedad de algoritmos de reconstrucción. Las técnicas más usadas son: La Proyección de Máxima Intensidad (PMI), representación de superficie (shaded surface display) y representación volumétrica (volume rendering).

Debido a los avances tanto en hardware como software que se han producido en los últimos años, se ha producido un cambio en la concepción de lo que el TC significaba. Ya no se trata de la presentación de imágenes axiales bidimensionales; hoy en día, se pueden presentar estudios en los diferentes planos del espacio en 2D (multiplanares-MPR), pero además podemos generar objetos en 3 dimensiones ofreciendo nuevas posibilidades diagnósticas, permitiendo la observación de estructuras desde infinidad de ángulos.

Los datos de una imagen médica digital son adquiridos y manipulados en una matriz de volumen de elementos llamada vóxeles. Una imagen se construye analizando cada vóxel y proyectando el resultado en una 
superficie bidimensional subdividida en elementos de imagen llamadas píxels.

La representación de superficie o de superficies sombreadas fue la primera técnica de representación tridimensional aplicada al diagnóstico médico. Esta técnica es un proceso mediante el cual se determinan superficies aparentes en el interior del volumen de datos, obteniéndose una imagen representando las superficies derivadas.

Trata el objeto 3D como si fuese totalmente opaco. El valor del sombreado para un vóxel está definido por la orientación original de la superficie y la localización del vóxel.

La Proyección de Máxima Intensidad (PMI) es una técnica de representación tridimensional que evalúa cada voxel a lo largo de una línea desde el ojo del observador a través del volumen de datos y selecciona el valor máximo de vóxel, que es el que se representa. Esta técnica de representación 3D, como la anterior, también está ampliamente extendida en los paquetes de software de diversas marcas comerciales de equipos, y su utilidad clínica ha sido extensamente evaluada. Se ha demostrado una técnica muy valiosa para la obtención de imágenes angiográficas tridimensionales, tanto en TC como en RM (Paul y Brian, 1999).

La representación volumétrica (Volume rendering), es una técnica de representación tridimensional que toma todo el volumen de datos y suma la contribución de cada vóxel a lo largo de una línea desde el ojo del observador a través del volumen de datos y representa la composición resultante para cada píxel de la pantalla (Drebin, 1988). La incorporación 
de información de todo el volumen de datos supone una mayor fidelidad a estos datos; sin embargo, para manejar estos volúmenes de información son necesarios procesadores muy potentes. Este es el motivo por el que esta técnica ha sido la última en incorporarse al resto de técnicas 3D rutinarias (Scott y Elliot, 1999).

Con el rápido e imparable avance de la tecnología aplicada a la medicina tenemos, en la posibilidad de obtención de imágenes en 3D, una nueva herramienta que sin duda ya actualmente, pero aun más, en un breve plazo de tiempo, va a aportar una nueva visión en el diagnóstico por la imagen, con la aparición a diario de nuevas aplicaciones. 


\section{CONCLUSIONES}


Tras generar una aplicación informática que visualiza, en tres dimensiones, los elementos anatómicos que integran la vía óptica y el sistema oculomotor, a partir de secciones seriadas de Resonancia Magnética hemos llegado a las siguientes conclusiones:

1a.-- El estudio con Resonancia Magnética de alta resolución constituye un buen método de diagnóstico por imagen, que permite identificar las estructuras que integran la vía óptica así como el sistema oculomotor (nervios y músculos extrínsecos), lo que facilitó su reconstrucción tridimensional a partir de las diferentes secciones seriadas.

2a.- Las novedosas técnicas informáticas de diseño gráfico por ordenador, empleadas en nuestro estudio, nos han permitido desarrollar imágenes tridimensionales reales de las estructuras anatómicas de la vía óptica y sistema oculomotor, desde secciones de resonancia magnética, proporcionando una nueva entidad en el campo de las ciencias de la salud, al posibilitar la creación y manipulación de imágenes médicas de estructuras corporales, con el objeto de originar entornos virtuales animados con fines docentes o prácticos 
3a.- Este desarrollo informático ha supuesto un buen recurso docente que permite mejorar los resultados evaluativos de los conocimientos sobre la vía óptica y sistema oculomotor; manifestado por los distintos usuarios que lo han empleado; probablemente esto haya sido debido a que estos sistemas de consulta interactivos, han motivado al estudio por ser muy dinámicos y atractivos.

4a.-- Los entornos de docencia, con programas informáticos, como el que hemos desarrollado, constituyen una forma nueva de tecnología formativa, donde el aprovechamiento de todo este potencial tecnológico, es de gran utilidad en la formación médica y en la práctica clínica, tal y como se ha reflejado tras efectuar una encuesta de satisfacción de la aplicación informática. Nuestro programa constituye una herramienta informática, rigurosamente cuidada, para que cualquier usuario en ciencias de la salud, puedan desarrollar, de forma autónoma, todo el proceso de enseñanza-aprendizaje para el conocimiento de la anatomía de la vía óptica y del sistema oculomotor, correlacionado con secciones de resonancia magnética en los tres planos espaciales.

5a y última.- Este procedimiento informático supone una herramienta muy valiosa como patrón de referencia anatómica tridimensional de estas estructuras, lo que ayudará a llevar a cabo planificaciones quirúrgicas, ante diversas patologías, permitiendo establecer el plan o vía de abordaje de la lesión, incluso evaluar virtualmente, según la exploración clínica, si el proceso es finalmente quirúrgico o no. 


\section{REFERENCIAS BIBLIOGRÁFICAS}


Abrahams P. 1998. McMinn's Interactive Clinical anatomy. Mosby, St Louis.

Adams L, Krybus W, Meyer-Ebrecht D. 1990. Computer-Assisted Surgery. IEEE Comput Graphics App, 10: 43-51.

Alberico RA, Husain SH, Sirotkin I. 2004. Imaging in head and neck oncology. Surg Oncol Clin N Am, 13:13-35.

Amat P. 1991. Escolar: Anatomía Humana. Funcional y aplicativa. $4^{\mathrm{a}}$ edición, tomo 2. Ed. Espaxs. Zaragoza.

American Academy of Ophtalmology. 2008. Curso de Ciencias básicas y Clínicas. Sección 5: Nueroftalmología. Elsevier. Barcelona.

Anatomía de Gray. 1998. Editor: Williams PL. $38^{\text {a }}$ edición. Tomo II. Harcourt-Brace. Madrid.

Anderson JS, Jay JS. 1987. Use and impact of computers in clinical medicine. New York, Springer-Verlag.

Aoki Y, Nishida Y, Hayashi O, Nakamura J, Oda S, Yamade S, Kani K. 2003. Magnetic resonance imaging measurements of extraocular muscle path shift and posterior eyeball prolapse from the muscle cone in acquired esotropia with high myopia. Am J Ophthalmol, 136(3):482-489.

Atlas SW, Galetta SL. 1991. The orbit and visual system. En: Atlas SW, editor: Magnetic resonance imaging of the brain and spine. Raven Press. New York, 709-722.

Avolio S. 1981. Planeamiento del Proceso de Enseñanza-Aprendizaje. Marymar S.A. Buenos Aires.

Azorín JM, Sabater JM, García NM, Pérez C. 2005. Avances en el desarrollo de un simulador para telecirugía. Actas del XXVI Jornadas de Automática. Alicante. 
Barnstable CJ. 1987. A molecular view of vertebrate retinal development. Mol Neurobiol, 1: 9-46.

Bartolomé A. 1989. Nuevas tecnologías y Enseñanza. Graó-ICE UB. Barcelona.

Basdogan L, Ho H, Srinivasan S, Small P, Dawson J. 1998. Force Interactions in Laparoscopic Simulations: Haptic Rendering of Soft Tissues. Proceedings of the Medicine Meets Virtual Reality Conference, San Diego,CA, Ja.

Bron AJ, Tripathi RC, Tripati BJ. 1997. Wolff's anatomy of the eye and orbit. Chapman\&Hall, London.

Bear MF, Connors BW, Paradiso MA. 2008. Neurociencia. La exploración del cerebro. Edit Wolters Klñuwer/Lippincott Williams \& Wilkins, Madrid.

Bulling A, Castrop F, Agneskirchner J, Rumitz M, Ovtscharoff W, Wurzinger LJ Gratzl M. 1999. BodyExplorer 2.0. Springer-Verlag, New York.

Burgielski Z, Jansen T, von Rymon-Lipinski B, Hanssen N, Keeve E. 2002. Julius-a software framework for computer-aided-surgery. Biomed Tech. 47 Suppl. 1 Pt 1:101-103.

Carmichael SW, Pawlina W. 2000. Animated Power-Point as a tool to teach anatomy. Anat Rec (New Anat), 261: 83-88.

Castillejo, Jl. 1986. Tecnología y Educación. CEAC. Barcelona.

Cattaneo L. 2007. Carne y cera: Los modelos anatómicos de Clemente Susini. Presentación de la colección de Cagliari. Elementos, 68: 35-37.

Chung MS, Kim MK, Park SK. 2000 a. Three-dimensional virtual dissection program of the heart using Korean cadaver. J Biomed Eng Res, 21:17-22.

Chung MS, Kim SY. 2000 b. Three-dimensional image and virtual dissection program of the brain made of Korean cadaver. Yonsei Med J, 41:299-303.

Clark RA, Miller JM, Rosenbaum AL, Demer JL. 1998. Heterotopic muscle pulleys or oblique muscle dysfunction? J Am Assoc Pediatr Ophthalmol Strabismus 2:17-25. 
Clark VP, Courchesne E, Grafe M. 1992. In vivo myeloarchitectonic analysis of human striate and extrastriate cortex using magnetic resonance imaging. Cereb Cortex, 2: 417-424.

Cooper A. 2004. About Face The Essentials of User Interface Design" Ed. IDG Books. ISBN de 1-56884-322-4.

Cotin S, Delingette H, Ayache N. 1996. Real time volumetric deformable models for surgery simulation. Visualization in Biomedical Computing (Proc. VBC'96). Höhne KH, Kikinis R (eds.). Lecture Notes in Computer Science, vol. 1131, Springer-Verlag.

Couteau B, Payan Y, Lavallée S. 2000. The mesh-matching algorithm: an automatic 3D mesh generator for finite element structures. J Biomech, 33:1005-1009.

Cunes JT, Burger PC, Djang WT, Boyko OB. 1988. MR imaging of compact white matter pathways. AJNR Am J Neuroradiol, 9: 1061-1068.

De Pablos J, Gortari C. 1992. Las nuevas tecnologías de la información en la educación. Alfar. Sevilla.

Demer JL, Miller JM, Poukens V, Vinters HV, Glasgow BJ. 1995. Evidence for fibromuscular pulleys of the recti extraocular muscles. Invest Ophthalmol Vis Sci 6:1125-1136.

Demer JL, Miller JM. 1995. Magnetic resonance imaging of the functional anatomy of the superior oblique muscle. Invest Ophthalmol Vis Sci 36:906-913.

DePotter P, Flanders AE,Shields CL,Shields JA. 1993. Magnetic resonance imaging of orbital tumors. Int Ophtalmol Clin, 33: 163-173.

Downes M, Hsu A, Steele M. 1997. A virtual environment for training laparoscopic chiolecystectomy. Univ. California. Berkeley CS294-5, Virtual Reality, spring Semester.

Drake RL. 1998. Anatomy education in a changing medical curriculum. Anat Rec (New Anat), 253: 28-31.

Drebin RA, Carpenter L, Hanrahan P. 1988. Volume rendering. Comput Graph ; 22: 65-74.

Dumoulin SO, Hoge RD, Baker CL Jr, Hess RF, Achtman RL, Evans AC. 2003. Automatic volumetric segmentation of human visual retinotopic cortex. Neuroimage, 18:576-587 
Dutton J. 1999. Orbital imaging techniques. En: Yanoff M Editor. Ophtalmology, $2^{\text {a }}$ edit. St. Louis: Mosby International Ltd, 649-654.

Ela-Dalman N, Velez FG, Demer JL, Rosenbaum AL. 2008. Highresolution magnetic resonance imaging demonstrates reduced inferior oblique muscle size in isolated inferior oblique palsy. J AAPOS, octubre 3 (presentación electrónica).

Ettl A, Kramer J, Daxer A, Koornneef L. 1997 a. High resolution magnetic resonance imaging of neurovascular orbital anatomy. Ophthalmology 104: 869-877.

Ettl A, Kramer J, Daxer A, Koornneef L. 1997 b. High-resolution magnetic resonance imaging of the normal extraocular musculature. Eye 11:793-797.

Ettl A, Salomonowitz E, Koornneef L, Zonneveld FW. 1998 a. Highresolution MR imaging anatomy of the orbit. Correlation with comparative cryosectional anatomy. Radiol Clin N Am 36:1021-1045.

Ettl A, Koornneef L, Daxer A, Kramer J. 1998 b. High-resolution magnetic resonance imaging of the orbital connective tissue system. Ophthalm Plast Reconstr Surg. 14:323-327.

Ettl A, Daxer A, Priglinger S, Kramer J, Koornneef L. 1998 c. Dynamic magnetic resonance imaging of the levator palpebrae superioris muscle. Ophthalm Res 30:54-58.

Ettl A, Salomonowitz E, Koornneef L. 2000 a. Magnetic resonanace imaging of the orbit: Basic principles and anatomy. Orbit, 19: 211-237.

Ettl A, Zwrtek K, Daxer A, Salomonowitz E. 2000 b. Magnetic resonance imaging anatomy of the orbital apex and cavernous sinus. Surv Ophthalmol 44:303-323.

Fielding JR, Dumanli H, Scheeyer AG, Okuda S, Gering DT, Zou KH, Kikinis R, Jolesz FA. 2000. MR-based three-dimensional modeling of the normal pelvic floor in women: quantification of muscle mass. AJR Am J Roentgenol, 174: 657-660.

Fraile Moreno E. 2007. Avances en el diagnóstico por imagen. Nuevos procedimientos tecnológicos. Indicaciones. Medicine 9(92): 5913-5920.

Fujita N, Tanaka H, Takanashi M, Hirabuki N, Abe K, Yoshimura H, Nakamura H. 2001. Lateral geniculate nucleus: anatomic and functional 
identification by use of MR imaging. AJNR Am J Neuroradiol, 22: 17191726.

General Electric Medical systems. Volume Analysis 2. User guide. 2001:239-255

Gibson S, Samosky J, Mor A. 1997. Simulating arthroscopic knee surgery using volumetric object rendering with real-time volume rendering. In: CVMRMed- MRCAS'97, 369-378. Springer-Verlag.

Gillies MFP y Dodgson NA. 2002. Eye movements and attention for behavioural animation. J Visual Comput Animat 13: 287-300.

González LC, Suarez E, Dos Santos V, Junceda J, Recio M, Martinez V, Viaño L. 2003. Dotación vasculonerviosa y espacios anatomoquirúrgicos de la órbita por resonancia magnética de alto campo. Arch Soc Esp Oftalmol, 78:549-554.

Gotwald TF, Menzler A, Beauchamp NJ, zur Nedden D, Zinreich SJ. 2003. Paranasal and orbital anatomy revisited: identification of the ethmoid arteries on coronal CT scans. Crit Rev Comput Tomogr 44: 263-278.

Grassi B. De oculis eorumque egritudinibus et curis. Ferrara: Severinus de Ferrara; 1474.

Grémy, F. 1986. Informatique Médicale. París, Flammarion.

Gutiérrez C. 1997. Medicina e Internet. Anaya Multimedia.A.A. Madrid.

Haines DE. 2003. Principios d Neurociencia. 2a edición. Elsevier Science, Madrid.

Hallgren RC, Parkhurst PE, Monson CL, Crewe NM. 2002. An interactive, web-based tool for learning anatomic landmarks. Acad Med, 77: 263-265.

Hernández González LC, López Muñiz A, Junceda Moreno J, Suárez Suárez E. 2002. Primeros documentos históricos sobre la vía óptica. Arch Soc Esp Oftalmol. 77: 639-640.

Hernández González LC, Suárez Suárez E, Dos Santos Bernardo V, Junceda Moreno J, Recio Rodríguez M, Martínez De Vega V, Viaño López J. 2003. Dotación vasculonerviosa y espacios anatomoquirúrgicos de la órbita por resonancia magnética de alto campo. Arch. Soc Esp Oftalmol. 78:549-554. 
Hoerantner R, Kaltofen T, Pringlinger S, Fock CM, Buchberger M, Haslwanter T. 2007. Model-based improvements in the treatment of patients with strabismus and axial high myopia. Invest Ophthalmol Vis Sci, 48:1133-1138.

Hoffman H, Murray M. 1999. Anatomic visualizer: Rendering the vision of a VR-based learning enviorement. Medicine Meets Virtual Reality, 7: 134-140.

Horton JC, Landau K, Maeder P, Hoyt WF. 1990. Magnetic resonance imaging of the human lateral geniculate body. Arch Neurol, 47: 1201-1206.

Hoyte L, Schierlitz L, Zou KG, Fleshg J. 2001. Two- and 3-dimensional MRI comparison of levator ani structure, volume, and integrity in women with stress incontinence and prolapse. Am J Obstet Gynecol, 185: 11-19.

Howden L, Giddings D, Power H, Aroussi A, Vloeberghs M, Garnett M, Walker D. 2008. Three-dimensional cerebrospinal fluid flow within the human ventricular system. Comput Methods Biomed Engin, 11:123-133.

Hubel DH. 2000. Ojo, cerebro y visión. Servicio Publicaciones. Universidad de Murcia.

Inostroza P. 2005. Real-time update of eye features on the 3D head model texture. Comp. Anim Virtual Worlds, 16: 129-136.

Iwamoto K, Tanie K, Maesa T. 1997. A head-mounted Eye movement tracking display and its image display method. Scripta Technica, Inc Syst Comp Jpn, 28: 89-99.

Jayaram K. 1999. Three-dimensional visualization and analysis methodologies: A current perspective. Radiographics, 19: 783-806.

Juanes JA, Espinel JL, Velasco MJ, Zoreda JL, Riesco JM, Carmena JJ, Blanco E, Marcos J, Vazquez R. 1996. A three-dimensional virtual model of the head generated from digitalized CT or MR images for anatomical-radiological and neurosurgical evaluations. J Neuroradiol, 23:211-216.

Juanes JA, Prats A, Lagándara ML, Riesco JM. 2003. Application of the "Visible Human Project" in the field of anatomy: a review. Eur J Anat, 7: $147-159$.

Juanes, J.A., Espinel, J.L., Velasco, M.J., Zoreda, J.L.,Riesco, J.M., Carmena, J.J., Blanco, E., Marcos, J. y Vázquez, R.A. 1996. Threedimensional virtual model of the head generated from digitalized CT and 
MR images for anatomical-radiological and neurosurgical evaluations. J Neuroradiol, 23: 211-216.

Juanes, J.A., Prats, A., Riesco, J.M., Blanco, E., Velasco, M.J., Cabrero, F.J. y Vázquez, R. 2001. Computerized model for the integration and neurosurgical evaluations. J. Anat, 5: 133-138.

Kaufman A. 1991. A tutorial on volume visualization. Los Alamitos, Calif: IEEE Computer Society.

Kaufman PL, Alm AA. 2007. ADLER. Fisiología del ojo. Aplicación clínica. $10^{\text {a }}$ edición. Elsevier, Madrid.

Kerr JP, Ratiu P, Sellberg M. 1996. Volume rendering of visible human data for an anatomical virtual environment. Stud Health Technol Inform, 29: $352-370$.

Kitajima M, Korogi Y, Takahashi M, Eto K. 1996. MR signal intensity of the optic radiation. AJNR Am J Neuroradiol, 17: 1379-1383.

Koenigsberg R, Faro SH, Hershey BL, Slegal TL, Mohamed FB, Dastur CK. 2003. Neuroimagin. En: Goetz I editor, Textbook of Clinical Neurology, $2^{a}$ edición. New York: Elesevier, 427-463.

Krzizok T, Kaufmann H, Traupe H. 1997. Elucidation of restrictive motility in high myopia by magnetic resonance imaging. Arch Ophthalmol 115:1019-1027.

Kuszyk BS, Heath DG, Bliss DF, Fishman EK. Skeletal 3D Ct. 1996. Adavantage of volume renderig over surface rendering. Skeletal Radiol, 25: 207-214

Larsen W.L. 2003. Embriología humana. $3^{\text {a }}$ edición. Edit. Elsevier Science. Madrid.

Lennerstrand G. 2007. Strabismus and eye muscle function. Acta Ophthalmol Scand, 85: 711-723.

López Espinosa JA. 2007. Contribución a la historia de la bibliografía cubana sobre Oftalmología. Acimed, 15 (3). Artículo disponible on-line en la dirección web: http://bvs.sld.cu/revistas/aci/vol15_3_07/aci06307.htm.

Mafee MF, Goodwin J, Dorodi S. 1999. Optic nerve sheath meningeomas. Role of MR imaging. Radiol Clin N Am. 37: 37-58. 
Mann F, Gatinel D, Morax S Hoang-Xuan T. 2006. Modélisation informatique tridimensionnelle de la cavité orbitaire et des paupières. J Fr Ophtalmol, 29: 381-390.

Marqués P. 1999. El software educativo. Universidad de Barcelona.

Masuko S, Hoshino J. 2006. Generating head-eye movement for virtual actor. Wiley Periodicals, Inc Syst Comp Jpn, 37:33-44.

Mathers PH, Grinberg A, Mohan MA, Jamrich M. 1997. The RX homeobox gene is essential for vertebrate eye development. Nature, 387: 603-607.

Mc Avoy JW, Chamberlain CG, De Iongh RV, Halles AM, Lovicu FJ. 1999. Lens development. Eye 13: 425-437.

McCracken TO. 2000. New Atlas of Human Anatomy. Edit. MetroBooks. Nueva York.

Mercader JM y Viñuela F. 2004. Neuroendocrinología diagnóstica y terapeútica. Edit. Masson, Madrid.

Miller SA, Perrotti W, Silverthorn DU, Dalley A Rarey K. 2002. From college to clinic: Reasoning over memorization is key for understanding anatomy. Anat Rec (New Anat), 269: 69-80.

Montserrat C. 1999. Modelos Deformables de Tejidos Elásticos en Tiempo Real. Tesis Doctoral. Universidad Politécnica de Valencia.

Monserrat C, Alcañiz M, Meier U, Poza J, Juan M, Grau V. 2000. Simulador para el entrenamiento en cirugías avanzadas. Universidad Politécnica de Valencia. www.dsic.upv.es/ cmonserr/Articulos/AA028 pdf.

Moore KL y Persaud TVN. 2008. Embriología Clínica. 8a edición. Edit. Elsevier. Madrid.

Muller W, Grosskopf S, Hildebrand A, Malkewitz R, Ziegler. R. 1997. Virtual reality in the operating room of the future. Stud Health Technol Inform, 39: 224-231.

Noden D. 1983. The role of the neural crest in patterning of avian cranial skeletal, connective, and muscle tissues. Dev. Biol, 96: 144-165.

Nolte J. 1994. El cerebro humano. Introducción a la anatomía functional. $3^{\text {a }}$ edición. Mosby/Doyma Libros, Madrid. 
O'Rahilly R. 1966. The early development of the eye in staged human embyos. Contrib. Embryol Carnegie Inst, 38: 1

O'Rahilly R. 1975. The prenatal development of the human eye. Exp Eye Res 21: 93-112.

O'Rahilly R. 1983. The timing and sequence of events in the devolpment of the human eye and ear during the embryonic period proper. Anat Embryol, 168: 87-99.

Ohtsuka K, Hashimoto M, Nakamura Y. 1997. Enhanced magnetic resonance imaging in a patient with acute paralysis of the inferior division of the oculomotor nerve. Am J Ophthalmol. 124: 406-409.

Olman C, Ronen I, Ugurbil K, Kim DS. 2003. Retinotopic mapping in cat visual cortex using high-field functional magnetic resonance imaging. Neurosci Methods, 131: 161-170.

Ortega P, Martinez F. 1994. Educación y Nuevas Tecnologías. Paraninfo. Madrid.

Ozkan SB, Aribal ME. 2007. Comparison of orbital magnetic resonance imaging in duane syndrome and abducens palsy. Am J Ophthalmol, 143: 907-908.

Paalman M. 2000. New frontiers in Anatomy Education. Anat Rec (New Anat), 261: 247.

Park JS, Chung MS, Hwang SB, Lee YS, Har DH, Park HS. 2005 a. Visible Korean Human: Improved serially sectioned images of the entire body. IEEE Trans Med Imaging 24: 352-360.

Park JS, Chung MS, Hwang SB, Lee YS, Har DH. 2005 b. Technical report on semiautomatic segmentation using the Adobe Photoshop. J Digit Imaging, 18:333-343.

Park JS, Chung MS, Hwang SB, Shin B, Park HS. 2006. Visible Korean Human: Its Techniques and Applications. Clinical Anatomy, 19: 216-224.

Paul S, Brian S. 1999. Three-dimensional volume rendered of spiral CT data: Theory and method. Inforad, 19: 745-764.

Pereira JA, Merí A, Molina-Ros A, Molina-Andreu O. 2003. Webbased course for teaching Human Anatomy. The UPF experience. Eur. J Anat, 7: 19-22. 
Pérez Moreiras JV, Prada Sánchez MC, Pérez Becerra E. 2000. Patología orbitaria: exploración, diagnóstico y cirugía (Tomo 1). Edika Med, Barcelona.

Perry JL, Kuehn DP. 2007. Three-dimensional computer reconstruction of the levator veli palatine muscle in situ using magnetic resonance imaging. Cleft Palate Craniofac J, 44: 421-423.

Pflesser B, Petersik A, Pommert A, Riemer M, Schubert R, Tiede U, Hohne Kh, Schumacher U, Richter E. 2001. Exploring the visible human's inner organs with the Voxel-Man 3D navigator. Stud Health Technol Inform, 81: 379-385.

Prats-Galino A, Santamaria S, Potau JM, Golanó P. 2000. Proyecto "Virtual Brain: Anatomía 3D y Seccional del Cerebro humano por la Web. Primer Congreso Internacional de Docencia universitaria e Innovación. Barcelona.

Primal pictures limited. 2007. Detailed Human Anatomy Series. 3D human anatomy software. http://www.primalpictures.com

Purves D, Augustine GJ, Fitzpatrick D, Hall WC, LaMantia AS, McNamara JO, Williams SM. 2007 Neurociencia. Editorial Médica Panamericana, Madrid.

Ramella M, Muci-Mendoza R. 2005. Neurorradiología en neurooftalmología. Gac Med Caracas, 113: 174-180.

Rapuano CJ, Luchs JI, Kim T. 2001. Los requisitos en oftalmología: segmento anterior Editorial Harcourt. Madrid.

Reindenberg JS, Laitman JT. 2002. The new face of gross Anatomy. Anat Rec (New Anat), 269: 81-88.

Renn WH, Rhoton Jr AL. 1975. Microsurgical anatomy of the the sellar region. J Neurosurg, 43: 288-298.

Rhee T, Lewis JP, Neumann U, Nayak K. 2008. Creating an animatable $3 \mathrm{D}$ volume hand model from in vivo MRI. Stud Health Technol Inform, 132:402-407.

Ricci P. 1999. Imaging of adult brain tumors. Neuroimaging. Clin North Am. 9: 651-669.

Riederer SJ. 2004. MR imaging: its development and the recent Nobel Prize. Radiology, 231: 628-631. 
Rifkin BJ, Ackerman MJ, Folkensberg J. 2006. Human Anatomy. Depicting yhe body from the Renaissance to Today. Edit. Thames \& Hudson. Londres.

Rivera Porto E. 1993. La computadora en la educación. Ed. Publicaciones Portorriqueñas. San Juan.

Robb RA. 2000. Virtual endoscopy: development and evaluation using the Visible Human Datasets. Computerized Medical Imaging and Graphics, 24: 133-151.

Rodríguez Lamas R. 2002. Introducción a la Informática Educativa. Pueblo y Educación, Ciudad de la Habana.

Rohen JH y Lütjen-Drecoll E. 2008. Embriología funcional. Una perspectiva desde la biología del desarrollo. $3^{\text {a }}$ edición Edit. Panamericana. Madrid.

Rouviere H y Delmas A. 2005. Anatomía Humana, descriptiva, topográfica y funcional. $11^{\text {a }}$ edición. Tomos I y IV. Edit. Masson. Madrid.

Royo, J. 2004. Diseño Digital. Ediciones Paidós Ibérica. Barcelona

Rubi I, Martinez MI, Vera R, Delgado MP, Lopez P. 2002. Síndrome de Kearns-Sayre: hallazgos en tomografía computerizada y resonancia magnética del sistema nervioso central. Anales españoles de Pediatria, 56:180-184.

Rubod C, Boukerrou M, Rousseau J, Viard R, Brieu M, Dubois P. 2006. A biomechanical model of the pelvic cavity: first steps. Conf Proc IEEE Eng Med Biol Soc, 1:968-971.

Runge VM. 2006. Advances in magnetic resonance. Invest Radiol, 41: 904-909.

Sadler TW. 2006. Langman Embriología Médica con orientación clínica. $10^{\mathrm{a}}$ edición. Edit. Medica Panamericana. Madrid .

Saha MS, Spann C, Grainger RM. 1989. Embryonic lens induction: more than meets the optic vesicle. Cell Differ Dev, 28: 153-171.

Salinas J. 1994. Hipertexto e hipermedia en la enseñanza universitaria. Pixel-Bit. Revista de Medios y Educación, 1: 15-29.

Saraux H, Lemasson CH, Offret H, Renard G. 1985. Anatomía e Histología del ojo. Ed. Masson, Barcelona. 
Saude T. 1993. Ocular Anatomy and Physiology. Oxford Blackwell Scientific Publications. Londres.

Schubert R, Schiemann T, Tiede U, Hohne KH. 1997. Applications and perspectives in anatomical 3-dimensional modelling of the visible human with Voxel-Man. Acta Anat, 160: 123-131.

Scott E, Elliot K. 1999. Volume-rendered three-dimensional Spiral CT: Musculo-skeletal aplications. Radiographics, 19: 1143-1160.

Sellheyer K. 1990. Development of the choroid and related structures. Eye, 4: 255-261.

Sevel D, Isaacs R. 1988. A re-evaluation of corneal development. Trans Am Ophthalmol Soc 86: 178-207.

Shattuck DW, Mirza M, Adisetiyo V, Hojatkashani C, Salamon G, Narr KL, Poldrack RA, Bilder RM, Toga AW. 2008. Construction of a 3D probabilistic atlas of human cortical structures. Neuroimage, 39:10641080 .

Shneiderman B. 1998. Designing The user interface, Strategies for effective Human-computer interaction. Addison-Wesley.

Shortliffe E, Perreault L. 1990. Medical informatics: Computer applications in health care. New York, Addison-Wesley.

Smith JM. 2007. "Escolar. Reconstrucciones Humanas por planos de disección". $4^{a}$ edición. Editorial Espaxs. Zaragoza.

Sora MC, Strobl B, Staykov D, Traxler H. 2002. Optic nerve compression analyzed by using plastination. Surg Radiol Anat 24: 205-208.

Spitzer VM, Ackerman MJ, Scherzinger AL, Whitlock DG. 1996. The visible human male: A technical report. J Am Med Inform Assoc, 3: 118130.

Squires, D., Preece, J. 1996. Usability and learning: evaluating the potential of educational software. Computers and Education, 27(1), 15-22.

Tam P. 1989. Regionalization of the mouse embryonic ectoderm: allocation of prospective extodermal tissues during gastrulation. Development 107: 55-67.

Tamraz J. 1994. Neuroradiologic investigation of the visual system using magnetic resonance imaging. J Clin Neurophysiol, 11:500-518. 
Tamraz JC, Outin-Tamraz C, Saban R. 1999. MR imaging anatomy of the optic pathways. Radiol Clin North Am, 37:1-36.

Taylor R, Lavallée S, Burdea G, Mosges R. 1996. Computer-integrated surgery. Technology and clinical applications. MIT Press, Cambridge MA.

Temkin B, Acosta E, Hatfield P, Onal E, Tong A. 2002. Web-based three-dimensional virtual body structures: W3D-VBS. J Am Med Inform Assoc, 9: 425-436.

Testut L y Latarjet A. 1969. Tratado de Anatomía Humana. Tomos II y III. Salvat Editores. Barcelona.

Tiede U, Bomans M, Höhne KH, Pommert A, Riemer M, Schiemann T, Schubert R, Lierse W. 1993. A computerized three-dimensional atlas of the human skull and brain. AJNR Am J Neuroradiol, 14:551-559.

Trelease R, Nieder G, Dorup J, Schacht Hansen M. 2000. Going virtual with quicktime VR: New methods and standardized tools for interactive dynamic visualization of anatomical structures. Anat Rec (New Anat), 261: 64-77.

Trelease RB. 1998. Toward virtual anatomy: A stereoscopic 3-D interactive multimedia computer program for cranial osteology. Clin Anat, 9: 269-272.

UNESCO. 1984.. Glossary of Educational Technology Terms. Paris.

Vanni S, Henriksson L, James AC. 2005. Multifocal fMRI mapping of visual cortical areas. Neuroimage, 27: 95-105.

Verhey JF, Nathan NS, Rienhoff O, Kikinis R, Rakebrandt F, D'Ambra MN. 2006. Finite-element-method (FEM) model generation of time-resolved 3D echocardiographic geometry data for mitral-valve volumetry. Biomed Eng Online, 5:17.

Viaño J, Martínez V, Hernández JC. 1999. Encephalon Atlas. Magnores Products SL, Madrid.

Villablanca JP, Martin N, Jahan R, Gobin YP, Frazee, Duckwiler G, Bentson J, Hardart M, Coiteiro D, Sayre J, Vinuela F. 2000. Volumerendered helical computerized tomography angiography in the detection and characterization of intracranial aneurysms. J Neurosurg, 93:254-264.

Villar, M; Mínguez, E. 1998. Guía de evaluación de software educativo. Grupo ORIXE. Euskadi. 
Vivancos Martí, J. 1996. "Entornos multimedia y aprendizaje". Comunicación Educativa y Nuevas Tecnologías, pp: 321-326. Barcelona: Praxis

Warnking J, Dojat M, Guérin-Dugué A, Delon-Martin C, Olympieff S, Richard N, Chéhikian A, Segebarth C. 2002. fMRI retinotopic mapping-step by step. Neuroimage, 17: 1665-1683.

Watchtler F. 1984. The extrinsic ocular muscles in birds are derived from the prechordal plate. Naturwissenschaften 71: 379-380.

White SC y Pharoah MJ. 2001. Radiología oral. Principios e interpretación. $4^{\mathrm{a}}$ edición. Elsevier Science. Madrid.

Wichmann W, Müller-Forell W. 2004. Anatomy of the visual system. European Journal of Radiology 49: 8-30.

Widmann G. 2007. Image-guided surgery and medical robotics in the cranial area. Biomed Imaging Interv J 2007; 3(1):e11. doi: 10.2349/biij.3.1.e11

Wilson-Pauwels L, Akesson E, Stewart PA y Spacey SD. 2003. Nervios Craneales. En la salud y la enfermedad. $2^{a}$ ed. Edit. Médica Panamericana, Madrid.

Wright KW. 1997. Embryology and eye development. En: Wright KW (ed): Textbook of Ophthalmology. Baltimore, Williams and Wilkins.

Wright K, Spiegel P. 2001. Oftalmología pediátrica y estrabismo: los requisitos en oftalmología. Editorial Harcourt. Madrid.

Zhang SX, Heng PA, Liu ZJ, Tan LW, Qiu MG, Li QY, Liao RX, Li K, Cui GY, Guo YL, Yang XP, Liu GJ, Shan JL, Liu JJ, Zhang WG, Chen XH, Chen JH, Chen W, Wang J, Lu M, You J, Pang XL, Xiao H, Xie YM. 2003. Creation of the Chinese visible human data set. Anat Rec. Part B: New Anat. 275B: 190-195

Zhang SX, Heng PA, Liu ZJ, Tan LW, Qiu MG, Li QY, Liao RX, Li K, Cui GY, Guo YL, Yang XP, Liu GJ, Shan JL, Liu JJ, Zhang WG, Chen XH, Chen JH, Wang J, Chen W, Lu M, You J, Pang XL, Xiao H, Xie YM, Cheng JC. 2004. The Chinese Visible Human (CVH) datasets incorporate technical and imaging advances on earlier digital humans. J Anat. 204:165-173. 
Ziegler R, Fischer G, Muller W, Gobel, M. 1995. A virtual reality medical training system. In: Ayache N (ed.), Proceedings of CVRMed'95, 282-286. Springer-Verlag.

Zurada A, St Gielecki J, Baron J, Zawiliński J, Kozlowska H. 2008. Interactive 3D stereoscopic digital-image analysis of the basilar artery bifurcation. Clin Anat. 21:127-137. 